\title{
Werkgelegenheid en scholing 1997.
}

Citation for published version (APA):

Researchcentrum voor Onderwijs en Arbeidsmarkt, ROA. (1998). Werkgelegenheid en scholing 1997.

Statistische bijlage. Researchcentrum voor Onderwijs en Arbeidsmarkt, Faculteit der Economische

Wetenschappen. ROA Reports No. 001B https://doi.org/10.26481/umarep.1998001B

Document status and date:

Published: 01/01/1998

DOI:

10.26481/umarep.1998001B

Document Version:

Publisher's PDF, also known as Version of record

\section{Please check the document version of this publication:}

- A submitted manuscript is the version of the article upon submission and before peer-review. There can be important differences between the submitted version and the official published version of record.

People interested in the research are advised to contact the author for the final version of the publication, or visit the DOI to the publisher's website.

- The final author version and the galley proof are versions of the publication after peer review.

- The final published version features the final layout of the paper including the volume, issue and page numbers.

Link to publication

\footnotetext{
General rights rights.

- You may freely distribute the URL identifying the publication in the public portal. please follow below link for the End User Agreement:

www.umlib.nl/taverne-license

Take down policy

If you believe that this document breaches copyright please contact us at:

repository@maastrichtuniversity.nl

providing details and we will investigate your claim.
}

Copyright and moral rights for the publications made accessible in the public portal are retained by the authors and/or other copyright owners and it is a condition of accessing publications that users recognise and abide by the legal requirements associated with these

- Users may download and print one copy of any publication from the public portal for the purpose of private study or research.

- You may not further distribute the material or use it for any profit-making activity or commercial gain

If the publication is distributed under the terms of Article $25 \mathrm{fa}$ of the Dutch Copyright Act, indicated by the "Taverne" license above, 


\title{
Statistische Bijlage Werkgelegenheid en scholing 1997
}

\author{
ROA-R-1998/1B
}

Researchcentrum voor Onderwijs en Arbeidsmarkt

Faculteit der Economische Wetenschappen en Bedrijfskunde Universiteit Maastricht

Maastricht, januari 1998 
ISBN 90-5321-220-5

SEC97.091/MvS 


\section{Inhoud}

Bladzijde

Voorwoord

Informatie naar bedrijfsgrootte

Tabel 1.1 Automatiseringsgraad naar bedrijfsgrootte,1994

Tabel 1.2 Percentage bedrijven met automatiseringspersoneel naar bedrijfsgrootte, 1994

Tabel 1.3 Automatiseringskosten per werknemer naar bedrijfsgrootte, 1994

Tabel 1.4 Gemiddelde omvang van de R\&D-activiteiten als percentage van de omzet en het percentage bedrijven met R\&D, naar bedrijfsgrootte, 1994

Tabel 1.5 Percentage R\&D voor vernieuwing van producten en diensten en voor de vernieuwing van productieprocessen, naar bedrijfsgrootte, 1994

Tabel 1.6 Percentage producten/diensten dat in de periode 1992-1994 is vernieuwd, naar bedrijfsgrootte, 1994

Tabel 1.7 Percentage bedrijven waarin sprake is geweest van organisatiewijzigingen in 1992-1994, naar bedrijfsgrootte, 1994

Tabel 1.8 Percentage bedrijven met bepaalde gevolgen van organisatiewijzigingen in 1992-1994, naar bedrijfsgrootte, 1994

Tabel 1.9 Percentage werkenden dat deelneemt aan bedrijfsopleidingen, naar bedrijfsgrootte, 1995-1996

Tabel 1.10 Percentage werknemers met geringe mobiliteitsbereidheid en feitelijke mobiliteit, naar bedrijfsgrootte, 1996

Tabel 1.11 Percentage werkenden dat niet breed inzetbaar is, naar bedrijfsgrootte, 1996

Informatie over bedrijfssectoren

Tabel 2.1 Percentage werknemers dat geconfronteerd wordt met lawaai tijdens het werk, naar bedrijfssector, 1996

Tabel 2.2 Percentage werknemers dat gebruik maakt van gereedschap of apparaten die trilling veroorzaken, naar bedrijfssector, 1996

Tabel 2.3 Percentage werknemers dat kracht moet zetten tijdens het werk, naar bedrijfssector, 1996

Tabel 2.4 Percentage werknemers dat werkzaam is in ploegendienst, naar bedrijfssector, 1996

Tabel 2.5 Percentage werknemers dat onder hoge tijdsdruk werkt, naar bedrijfssector, 1996

Tabel 2.6 Automatiseringsgraad naar bedrijfssector, 1994

Tabel 2.7 Percentage bedrijven met automatiseringspersoneel naar bedrijfssector, 1994

Tabel 2.8 Automatiseringskosten per werknemer naar bedrijfssector, 1994 
Tabel 2.9 Gemiddelde omvang van de R\&D-activiteiten als percentage van de omzet en het percentage bedrijven met R\&D, naar bedrijfssector, 1994

Tabel 2.10 Het percentage R\&D voor vernieuwing van producten en diensten en voor vernieuwing van productieprocessen, naar bedrijfssector, 1994

Tabel 2.11 Percentage producten/diensten dat in de periode 1992-1994 is vernieuwd, naar bedrijfssector, 1994

Tabel 2.12 Percentage bedrijven waarin sprake is geweest van organisatiewijzigingen in 1992-1994, naar bedrijfssector, 1994

Tabel 2.13 Percentage bedrijven met bepaalde gevolgen van organisatiewijzigingen, naar bedrijfssector, 1994

Tabel 2.14 Mate van informatisering naar bedrijfssector, 1996

Tabel 2.15 Ontwikkeling aantal werkenden 1992-1996 en uitbreidingsvraag 1997-2002 naar bedrijfssector (gemiddelde jaarlijkse percentages)

Tabel 2.16 Percentage werkenden dat deelneemt aan bedrijfsopleidingen, naar bedrijfssector, gemiddelde 1995-1996

Tabel 2.17 Employability-indicatoren naar bedrijfssector, 1996

Risicoprofielen naar bedrijfssector

Informatie over beroepen

Tabel 3.1 Percentage werknemers dat geconfronteerd wordt met lawaai tijdens het werk, naar beroepsgroep, 1996

Tabel 3.2 Percentage werknemers dat geconfronteerd wordt met lawaai tijdens het werk, naar beroepssegment, 1996

Tabel 3.3 Percentage werknemers dat gebruik maakt van gereedschap of apparaten die trilling veroorzaken, naar beroepsgroep, 1996

Tabel 3.4 Percentage werknemers dat gebruik maakt van gereedschap of apparaten die trilling veroorzaken, naar beroepssegment, 1996

Tabel 3.5 Percentage werknemers dat kracht moet zetten tijdens het werk, naar beroepsgroep, 1996

Tabel 3.6 Percentage werknemers dat kracht moet zetten tijdens het werk, naar beroepssegment, 1996

Tabel 3.7 Percentage werknemers dat werkzaam is in ploegendienst, naar beroepsgroep, 1996

Tabel 3.8 Percentage werknemers dat werkzaam is in ploegendienst, naar beroepssegment, 1996

Tabel 3.9 Percentage werknemers dat onder hoge tijdsdruk werkt, naar beroepsgroep, 1996

Tabel 3.10 Percentage werknemers dat onder hoge tijdsdruk werkt, naar beroepssegment, 1996

Tabel 3.11 Mate van informatisering naar beroepsgroep, 1996

Tabel 3.12 Mate van informatisering naar beroepssegment, 1996

Tabel 3.14 Verwachte sectorale reallocatie naar beroepssegment, 1997-2002

Tabel 3.15 Verwachte krimp-kengetallen voor beroepssegmenten per bedrijfssector, 1997-2002

Tabel 3.16 Oververtegenwoordiging van ouderen (50-64) ten opzichte van andere werkenden naar beroepsgroep en opleidingsniveau, 1995-1996 
Tabel 3.17 Percentage werkenden dat deelneemt aan bedrijfsopleidingen, naar beroepssegment, gemiddelde 1995-1996

Tabel 3.18 Employability-indicatoren naar beroepssegment, 1996

Tabel 3.19 Overzicht van perspectiefrijke omscholingsmogelijkheden naar andere beroepsgroepen per beroepssegment en de daarvoor vereiste additionele vaardigheden

Informatie over opleidingen

Tabel 4.1 Percentage werknemers dat geconfronteerd wordt met lawaai tijdens het werk, naar opleidingstype, 1996

Tabel 4.2 Percentage werknemers dat gebruik maakt van gereedschap of apparaten die trilling veroorzaken, naar opleidingstype, 1996

Tabel 4.3 Percentage werknemers dat kracht moet zetten tijdens het werk, naar opleidingstype, 1996

Tabel 4.4 Percentage werknemers dat werkzaam is in ploegendienst, naar opleidingstype, 1996

Tabel 4.5 Percentage werknemers dat onder hoge tijdsdruk werkt, naar opleidingstype, 1996

Tabel 4.6 Mate van informatisering naar opleidingstype, 1996

Tabel 4.7 Verwachte krimp-kengetallen voor opleidingstypen per beroepssegment, 1997-2002

Tabel 4.8 Opleidingseffect naar opleidingstype, 1997-2002

Tabel 4.9 Percentage werkenden dat deelneemt aan bedrijfsopleidingen, naar opleidingsrichting, 1995-1996

Tabel 4.10 Employability-indicatoren naar opleidingsrichting, 1996

Tabel 4.11 Overzicht van perspectiefrijke omscholingsmogelijkheden naar andere opleidingstypen per opleidingsrichting 



\section{Voorwoord}

Werkgelegenheid en scholing 1997 en deze bijbehorende Statistische Bijlage is de tweede versie van een jaarlijks uit te brengen overzichtsrapport in het kader van het Werkgelegenheid en Scholing Observatorium (WSO) van het Researchcentrum voor Onderwijs en Arbeidsmarkt $(R O A)$. Dit observatorium is door het Ministerie van Sociale Zaken en Werkgelegenheid ingesteld in het kader van de stimuleringsprogramma's ESF-4 Scholing voor behoud van werk en ADAPT van de Europese Commissie.

Het observatorium heeft als doel de voor het scholingsbeleid relevante ontwikkelingen op continue basis in beeld te brengen. Het WSO fungeert daarbij als een centraal punt, waar de relevante ontwikkelingen en prognoses met betrekking tot de werkgelegenheid en kwalificatiebehoeften met elkaar in verband worden gebracht, om zo tijdig inzicht te krijgen in de scholingsactiviteiten binnen branches en bedrijven en de lacunes die op dit punt optreden.

Het observatorium-karakter van dit onderzoek wordt weerspiegeld door het grote aantal indicatoren dat de revue passeert. Deze kengetallen hebben steeds als doel opvallende factoren of ontwikkelingen te signaleren. Deze Statistische Bijlage beoogt op dit punt te fungeren als een naslagwerk, waarin op systematische wijze een totaaloverzicht wordt gegeven van de in het hoofdrapport besproken indicatoren verbijzonderd naar bedrijfsgrootte, bedrijfssector, beroep of opleiding.

Uitgangspunt voor zowel het hoofdrapport als deze Statistische Bijlage is dat indicatoren gepresenteerd worden op het laagst mogelijke aggregatieniveau waarbij betrouwbaarheid en volledigheid nog gewaarborgd zijn. Daarom worden in deze bijlage bepaalde indicatoren op verschillende aggregatieniveaus gepresenteerd. Zo staan er in deze bijlage bijvoorbeeld zowel gegevens met betrekking tot bedrijfssectoren op een laag aggregatieniveau ( 35 sectoren) als op een hoog aggregatieniveau ( 13 sectoren). Indicatoren per beroep worden ook op 2 verschillende niveaus gepresenteerd. Indien mogelijk wordt een gedetailleerde indeling in 127 beroepsgroepen gehanteerd. Daarnaast wordt dezelfde informatie dan ook op het hogere aggregatieniveau van 43 beroepssegmenten gepresenteerd. Ook indicatoren per opleiding komen zowel op het lage niveau van 104 opleidingstypen als op het hogere aggregatieniveau (28 opleidingsrichtingen) aan de orde.

Wanneer niet voldaan wordt aan de ondergrens voor publicatie of wanneer het gegeven onbekend is, wordt dit in de tabellen aangegeven met een -.

De gepresenteerde indicatoren worden telkens ook kwalitatief getypeerd, uiteenlopend van 'erg laag' tot 'erg hoog'. Daarbij gaat het in de meeste gevallen om een relatieve typering ten opzichte van de andere bedrijfsgroottes, bedrijfssectoren, beroepen of opleidingen. $\mathrm{Er}$ zal in deze Statistische Bijlage niet uitgebreid worden ingegaan op de databronnen en de methodiek die ten grondslag liggen aan de gepresenteerde indicatoren. Hierop wordt ingegaan in het werkdocument Methodiek werkgelegenheid en scholing 1997.

De projectleiding van het WSO is in handen van dr. A. de Grip. Daarnaast is aan het onderzoek meegewerkt door drs. J.B. van Loo, J.M.A.F. Sanders, H. Schonk, drs. W. Smits, drs. M.S.M. van Smoorenburg, drs. M.J. de Steur en drs. R.A.M.H.M. Welters. Onze dank gaat uit naar de leden van de begeleidingscommissie. Deze commissie bestaat uit de volgende leden: drs. M.G. Drewes, drs. F. Straatjes en drs. J.C. van der Velden. 

INFORMATIE NAAR BEDRIJFSGROOTTE 

Tabel 1.1

Automatiseringsgraad naar bedrijfsgrootte, 1994

\begin{tabular}{|c|c|c|c|}
\hline \multirow[t]{2}{*}{ Bedrijfsgrootte } & \multicolumn{2}{|c|}{$\begin{array}{c}\text { automatiseringsgraad } \\
1994\end{array}$} & \multirow{2}{*}{$\begin{array}{l}\text { trend } \\
1990-1994\end{array}$} \\
\hline & $\%$ & typering & \\
\hline $\begin{array}{l}5-9 \text { werknemers } \\
10-19 \text { werknemers } \\
20-49 \text { werknemers } \\
50-99 \text { werknemers } \\
100-199 \text { werknemers } \\
200-499 \text { werknemers } \\
500 \text { of meer werknemers }\end{array}$ & $\begin{array}{l}64 \\
76 \\
87 \\
92 \\
95 \\
97 \\
98\end{array}$ & $\begin{array}{l}\text { laag } \\
\text { gemiddeld } \\
\text { hoog } \\
\text { erg hoog } \\
\text { erg hoog } \\
\text { erg hoog } \\
\text { erg hoog }\end{array}$ & $\begin{array}{l}\text { fluctuerend } \\
\text { constant } \\
\text { constant } \\
\text { fluctuerend } \\
\text { fluctuerend } \\
\text { constant } \\
\text { fluctuerend }\end{array}$ \\
\hline Totaal & 75 & & constant \\
\hline
\end{tabular}

Bron: CBS/ROA

Tabel 1.2

Percentage bedrijven met automatiseringspersoneel naar bedrijfsgrootte, 1994

\begin{tabular}{|c|c|c|c|}
\hline Bedrijfsgrootte & \multicolumn{2}{|c|}{$\begin{array}{l}\text { percentage bedrijven met } \\
\text { automatiseringspersoneel } 1994 \\
\% \quad \text { typering }\end{array}$} & $\begin{array}{l}\text { trend } \\
1991-1994\end{array}$ \\
\hline $\begin{array}{l}5-9 \text { werknemers } \\
10-19 \text { werknemers } \\
20-49 \text { werknemers } \\
50-99 \text { werknemers } \\
100-199 \text { werknemers } \\
200-499 \text { werknemers } \\
500 \text { of meer werknemers }\end{array}$ & $\begin{array}{r}5 \\
8 \\
17 \\
35 \\
54 \\
71 \\
88\end{array}$ & $\begin{array}{l}\text { gemiddeld } \\
\text { gemiddeld } \\
\text { gemiddeld } \\
\text { hoog } \\
\text { erg hoog } \\
\text { erg hoog } \\
\text { erg hoog }\end{array}$ & $\begin{array}{l}\text { sterk dalend } \\
\text { sterk dalend } \\
\text { dalend } \\
\text { dalend } \\
\text { constant } \\
\text { constant } \\
\text { fluctuerend }\end{array}$ \\
\hline Totaal & 13 & & dalend \\
\hline
\end{tabular}

Bron: CBS/ROA

Tabel 1.3

Automatiseringskosten per werknemer naar bedrijfsgrootte, 1994

\begin{tabular}{lcll}
\hline Bedrijfsgrootte & automatiseringskosten per werknemer & $\begin{array}{c}\text { t994 } \\
\text { typering }\end{array}$ & $1990-1994$ \\
\hline 5-9 werknemers & $f$ & gemiddeld & dalend \\
10-19 werknemers & 2.800 & gemiddeld & stijgend \\
20-49 werknemers & 3.000 & gemiddeld & fluctuerend \\
50-99 werknemers & 2.400 & fluctuerend \\
100-199 werknemers & 3.300 & gemiddeld & flucturerend \\
$200-499$ werknemers & 3.600 & gemidddeld & stijgend \\
500 of meer werknemers & 4.700 & & stijgend \\
Totaal & 8.400 & & stijgend \\
\hline
\end{tabular}

Bron: CBS/ROA 
Tabel 1.4

Gemiddelde omvang van de R\&D-activiteiten als percentage van de omzet en het percentage bedrijven met $R \& D$, naar bedrijfsgrootte, 1994

\begin{tabular}{|c|c|c|c|c|}
\hline Bedrijfsgrootte & \multicolumn{2}{|c|}{$\begin{array}{l}\text { gemiddelde omvang } \\
R \& D\end{array}$} & \multicolumn{2}{|c|}{$\begin{array}{l}\text { percentage bedrijven } \\
\text { met R\&D }\end{array}$} \\
\hline $\begin{array}{l}5-9 \text { werknemers } \\
10-19 \text { werknemers } \\
20-99 \text { werknemers } \\
100-499 \text { werknemers } \\
500 \text { en meer werknemers }\end{array}$ & $\begin{array}{l}1,9 \\
3,5 \\
2,5 \\
5,4 \\
4,6\end{array}$ & $\begin{array}{l}\text { gemiddeld } \\
\text { gemiddeld } \\
\text { gemiddeld } \\
\text { gemiddeld } \\
\text { gemidddeld }\end{array}$ & $\begin{array}{l}19 \\
27 \\
38 \\
56 \\
62\end{array}$ & $\begin{array}{l}\text { laag } \\
\text { gemiddeld } \\
\text { hoog } \\
\text { erg hoog } \\
\text { erg hoog }\end{array}$ \\
\hline Totaal & 4,2 & & 29 & \\
\hline
\end{tabular}

Bron: OSA/ROA

Tabel 1.5

Percentage R\&D voor vernieuwing van producten en diensten en voor de vernieuwing van productieprocessen, naar bedrijfsgrootte, 1994

\begin{tabular}{lcccc}
\hline Bedrijfsgrootte & \multicolumn{2}{c}{$\begin{array}{l}\text { vernieuwing } \\
\text { producten en diensten } \\
\text { typering }\end{array}$} & $\begin{array}{l}\text { vernieuwing } \\
\text { productieprocessen } \\
\text { typering }\end{array}$ \\
\hline $5-9$ werknemers & 9 & erg laag & erg laag \\
$10-19$ werknemers & 14 & erg laag & 6 & erg laag \\
$20-99$ werknemers & 23 & laag & 8 & erg laag \\
$100-499$ werknemers & 30 & laag & 11 & laag \\
500 en meer werknemers & 50 & gemiddeld & 33 & hoog \\
Total & 40 & & 26 & \\
\hline
\end{tabular}

Bron: OSA/ROA

Tabel 1.6

Percentage producten/diensten dat in de periode 1992-1994 is vernieuwd, naar bedrijfsgrootte, 1994

\begin{tabular}{|c|c|c|c|c|}
\hline \multirow{2}{*}{$\begin{array}{l}\text { Bedrijfsgrootte } \\
\text { 5-9 werknemers } \\
10-19 \text { werknemers } \\
20-99 \text { werknemers } \\
100-499 \text { werknemers } \\
500 \text { en meer werknemers }\end{array}$} & \multicolumn{2}{|c|}{$\begin{array}{l}\text { vernieuwing op } \\
\text { enkele aspecten } \\
\% \quad \text { typering }\end{array}$} & \multicolumn{2}{|c|}{$\begin{array}{l}\text { ingrijpende } \\
\text { vernieuwing } \\
\% \quad \text { typering }\end{array}$} \\
\hline & $\begin{array}{r}9 \\
11 \\
15 \\
16 \\
26\end{array}$ & $\begin{array}{l}\text { erg laag } \\
\text { erg laag } \\
\text { laag } \\
\text { laag } \\
\text { gemiddeld }\end{array}$ & $\begin{array}{r}8 \\
12 \\
10 \\
10 \\
15\end{array}$ & $\begin{array}{l}\text { laag } \\
\text { gemiddeld } \\
\text { gemiddeld } \\
\text { gemiddeld } \\
\text { gemiddeld }\end{array}$ \\
\hline Totaal & 22 & & 13 & \\
\hline
\end{tabular}

Bron: OSA/ROA 
Tabel 1.7

Percentage bedrijven waarin sprake is geweest van organisatiewijzigingen in 1992-1994, naar bedrijfsgrootte, 1994

\begin{tabular}{|c|c|c|c|c|}
\hline \multirow{2}{*}{$\begin{array}{l}\text { Bedrijfsgrootte } \\
\text { 5-9 werknemers } \\
10-19 \text { werknemers } \\
20-99 \text { werknemers } \\
100-499 \text { werknemers } \\
500 \text { en meer werknemers }\end{array}$} & \multicolumn{2}{|c|}{$\begin{array}{l}\text { verandering } \\
\text { positie bedrijf } \\
\% \quad \text { typering }\end{array}$} & \multicolumn{2}{|c|}{$\begin{array}{l}\text { interne } \\
\text { reorganisaties } \\
\% \quad \text { typering }\end{array}$} \\
\hline & $\begin{array}{r}3 \\
6 \\
10 \\
11 \\
13\end{array}$ & $\begin{array}{l}\text { laag } \\
\text { gemiddeld } \\
\text { hoog } \\
\text { hoog } \\
\text { erg hoog }\end{array}$ & $\begin{array}{r}9 \\
9 \\
13 \\
15 \\
39\end{array}$ & $\begin{array}{l}\text { erg laag } \\
\text { erg laag } \\
\text { laag } \\
\text { laag } \\
\text { hoog }\end{array}$ \\
\hline Totaal & 6 & & 29 & \\
\hline
\end{tabular}

Bron: OSA/ROA 


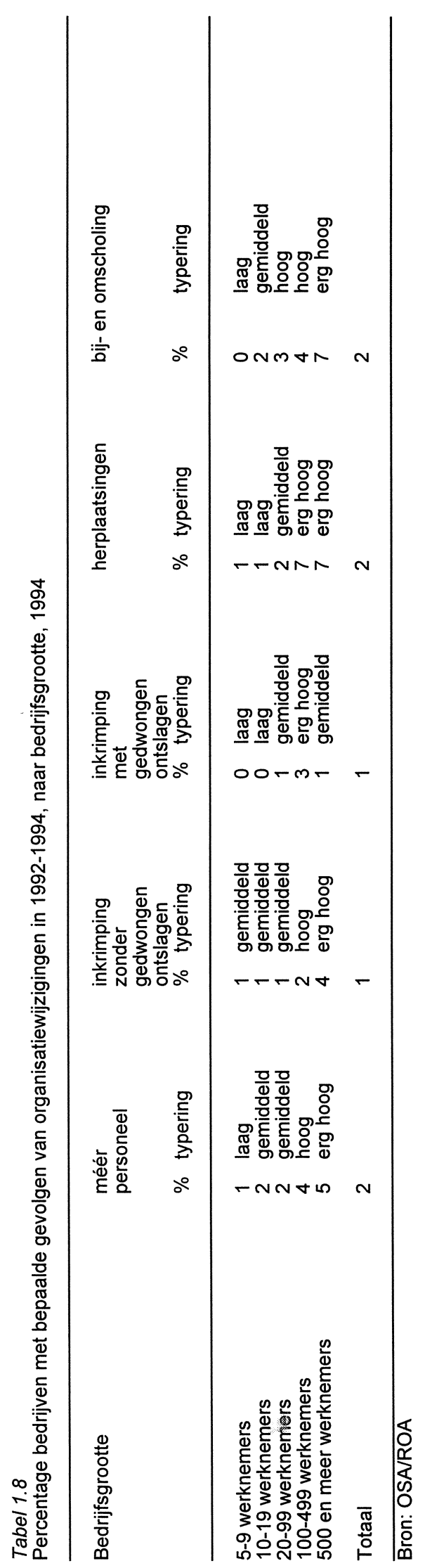


Tabel 1.9

Percentage werkenden dat deelneemt aan bedrijfsopleidingen, naar bedrijfsgrootte, 1995-1996

Bedrijfsgrootte

1-9 werknemers

10-99 werknemers

100 en meer werknemers

Bron: CBS/ROA

Tabel 1.10

Percentage werknemers met geringe mobiliteitsbereidheid en feitelijke mobiliteit, naar bedrijfsgrootte, 1996.

\begin{tabular}{lccc}
\hline Bedrijfsgrootte & $\begin{array}{c}\text { niet van functie } \\
\text { veranderd } \\
\%\end{array}$ & $\begin{array}{c}\text { niet actief } \\
\text { gezocht } \\
\%\end{array}$ & $\begin{array}{c}\text { ervarings- } \\
\text { concentratie } \\
\%\end{array}$ \\
\hline $1-9$ werknemers & 65 & 93 & 21 \\
$10-99$ werknemers & 75 & 92 & 24 \\
100 en meer werknemers & 74 & 90 & 25 \\
\hline Bron: OSA/ROA & &
\end{tabular}

Bron: OSA/ROA

Tabel 1.11

Percentage werkenden dat niet breed inzetbaar is, naar bedrijfsgrootte, 1996

\begin{tabular}{lc} 
Bedrijfsgrootte & $\%$ \\
\hline
\end{tabular}

1-9 werknemers

10-99 werknemers $\quad 25$

100 en meer werknemers $\quad 26$

Bron: OSA/ROA 



\section{INFORMATIE OVER BEDRIJFSSECTOREN}



Tabel 2.1

Percentage werknemers dat geconfronteerd wordt met lawaai tijdens het werk, naar bedrijfssector, 1996

\begin{tabular}{|c|c|c|}
\hline Bedrijfssector & $\%$ & typering \\
\hline Landbouw en visserij & 29 & gemiddeld \\
\hline $\begin{array}{l}\text { Tuinbouw } \\
\text { Veehouderij } \\
\text { Akkerbouw, bosbouw en visserij }\end{array}$ & $\begin{array}{r}19 \\
38 \\
-\end{array}$ & $\begin{array}{l}\text { laag } \\
\text { gemiddeld } \\
\text { gemiddeld }\end{array}$ \\
\hline Voeding & 46 & hoog \\
\hline $\begin{array}{l}\text { Vlees- en visverwerking } \\
\text { Overige voedingsproducten } \\
\text { Drank en tabaksproducten }\end{array}$ & $\begin{array}{l}57 \\
43 \\
49\end{array}$ & $\begin{array}{l}\text { hoog } \\
\text { gemiddeld } \\
\text { hoog }\end{array}$ \\
\hline Chemie & 42 & gemiddeld \\
\hline $\begin{array}{l}\text { Basischemie } \\
\text { Eindproducten chemie } \\
\text { Kunststofverwerking }\end{array}$ & $\begin{array}{l}44 \\
27 \\
59\end{array}$ & $\begin{array}{l}\text { gemiddeld } \\
\text { gemiddeld } \\
\text { erg hoog }\end{array}$ \\
\hline Metaal en elektrotechniek & 42 & gemiddeld \\
\hline $\begin{array}{l}\text { Basismetaal } \\
\text { Metaalproducten } \\
\text { Machine-industrie } \\
\text { Elektrotechniek } \\
\text { Transportmiddelen }\end{array}$ & $\begin{array}{l}59 \\
45 \\
45 \\
23 \\
52\end{array}$ & $\begin{array}{l}\text { erg hoog } \\
\text { hoog } \\
\text { hoog } \\
\text { gemiddeld } \\
\text { hoog }\end{array}$ \\
\hline Overige industrie & 42 & gemiddeld \\
\hline $\begin{array}{l}\text { Textiel } \\
\text { Hout- en bouwmaterialen } \\
\text { Papier } \\
\text { Grafische industrie }\end{array}$ & $\begin{array}{l}43 \\
59 \\
58 \\
28\end{array}$ & $\begin{array}{l}\text { gemiddeld } \\
\text { erg hoog } \\
\text { erg hoog } \\
\text { gemiddeld }\end{array}$ \\
\hline Energie & 24 & gemiddeld \\
\hline Bouw en onroerend goed & 41 & gemiddeld \\
\hline $\begin{array}{l}\text { Bouw } \\
\text { Exploitatie van onroerend goed }\end{array}$ & 45 & $\begin{array}{l}\text { gemiddeld } \\
\text { erg laag }\end{array}$ \\
\hline Handel & 14 & laag \\
\hline Transport en communicatie & 25 & gemiddeld \\
\hline $\begin{array}{l}\text { Scheep- en luchtvaart } \\
\text { Weg-en railvervoer } \\
\text { Communicatie }\end{array}$ & $\begin{array}{l}52 \\
24 \\
14\end{array}$ & $\begin{array}{l}\text { hoog } \\
\text { gemiddeld } \\
\text { laag }\end{array}$ \\
\hline Bank- en verzekeringswezen & 6 & erg laag \\
\hline $\begin{array}{l}\text { Bankwezen } \\
\text { Verzekeringswezen }\end{array}$ & 6 & $\begin{array}{l}\text { erg laag } \\
\text { erg laag }\end{array}$ \\
\hline Horeca, reparatie en zakelijke dienstverlening & 18 & laag \\
\hline $\begin{array}{l}\text { Horeca } \\
\text { Reparatie } \\
\text { Zakelijke dienstverlening } \\
\text { Overige commerciële dienstverlening }\end{array}$ & $\begin{array}{l}25 \\
40 \\
11 \\
27\end{array}$ & $\begin{array}{l}\text { gemiddeld } \\
\text { gemiddeld } \\
\text { erg laag } \\
\text { gemiddeld }\end{array}$ \\
\hline Kwartaire diensten & 13 & laag \\
\hline $\begin{array}{l}\text { Gezondheidszorg } \\
\text { Overige kwartaire diensten }\end{array}$ & $\begin{array}{l}13 \\
16\end{array}$ & $\begin{array}{l}\text { laag } \\
\text { laag }\end{array}$ \\
\hline
\end{tabular}


Tabel 2.1 (vervolg)

Percentage werknemers dat geconfronteerd wordt met lawaai tijdens het werk, naar bedrijfssector, 1996

\begin{tabular}{lll}
\hline Bedrijfssector & $\%$ & typering \\
\hline Overheid en onderwijs & 19 & laag \\
Onderwijs & 23 & gemiddeld \\
Overheid & 15 & laag \\
\hline Bron: CBS/ROA & & \\
\hline
\end{tabular}

Bron: CBS/ROA 
Tabel 2.2

Percentage werknemers dat gebruik maakt van gereedschap of apparaten die trilling veroorzaken, naar bedrijfssector, 1996

\begin{tabular}{|c|c|c|}
\hline Bedrijfssector & $\%$ & typering \\
\hline Landbouw en visserij & 32 & hoog \\
\hline $\begin{array}{l}\text { Tuinbouw } \\
\text { Veehouderij } \\
\text { Akkerbouw, bosbouw en visserij }\end{array}$ & $\begin{array}{r}18 \\
46 \\
-\end{array}$ & $\begin{array}{l}\text { gemiddeld } \\
\text { erg hoog } \\
\text { hoog }\end{array}$ \\
\hline Voeding & 15 & gemiddeld \\
\hline $\begin{array}{l}\text { Vlees- en visverwerking } \\
\text { Overige voedingsproducten } \\
\text { Drank en tabaksproducten }\end{array}$ & 16 & $\begin{array}{l}\text { gemiddeld } \\
\text { gemiddeld } \\
\text { gemiddeld }\end{array}$ \\
\hline Chemie & 21 & gemiddeld \\
\hline $\begin{array}{l}\text { Basischemie } \\
\text { Eindproducten chemie } \\
\text { Kunststofverwerking }\end{array}$ & $\begin{array}{l}23 \\
13 \\
31\end{array}$ & $\begin{array}{l}\text { gemiddeld } \\
\text { gemiddeld } \\
\text { hoog }\end{array}$ \\
\hline Metaal en elektrotechniek & 31 & hoog \\
\hline $\begin{array}{l}\text { Basismetaal } \\
\text { Metaalproducten } \\
\text { Machine-industrie } \\
\text { Elektrotechniek } \\
\text { Transportmiddelen }\end{array}$ & $\begin{array}{l}36 \\
34 \\
36 \\
16 \\
43\end{array}$ & $\begin{array}{l}\text { hoog } \\
\text { hoog } \\
\text { hoog } \\
\text { gemiddeld } \\
\text { erg hoog }\end{array}$ \\
\hline Overige industrie & 21 & gemiddeld \\
\hline $\begin{array}{l}\text { Textiel } \\
\text { Hout- en bouwmaterialen } \\
\text { Papier } \\
\text { Grafische industrie }\end{array}$ & $\begin{array}{r}18 \\
42 \\
23 \\
9\end{array}$ & $\begin{array}{l}\text { gemiddeld } \\
\text { hoog } \\
\text { gemiddeld } \\
\text { gemiddeld }\end{array}$ \\
\hline Energie & 17 & gemiddeld \\
\hline Bouw en onroerend goed & 48 & erg hoog \\
\hline $\begin{array}{l}\text { Bouw } \\
\text { Exploitatie van onroerend goed }\end{array}$ & 53 & $\begin{array}{l}\text { erg hoog } \\
\text { laag }\end{array}$ \\
\hline Handel & 9 & gemiddeld \\
\hline Transport en communicatie & 10 & gemiddeld \\
\hline $\begin{array}{l}\text { Scheep- en luchtvaart } \\
\text { Weg- en railvervoer } \\
\text { Communicatie }\end{array}$ & $\begin{array}{r}17 \\
12 \\
-\end{array}$ & $\begin{array}{l}\text { gemiddeld } \\
\text { gemiddeld } \\
\text { erg laag }\end{array}$ \\
\hline Bank- en verzekeringswezen & - & erg laag \\
\hline $\begin{array}{l}\text { Bankwezen } \\
\text { Verzekeringswezen }\end{array}$ & - & $\begin{array}{l}\text { erg laag } \\
\text { erg laag }\end{array}$ \\
\hline Horeca, reparatie en zakelijke dienstverlening & 11 & gemiddeld \\
\hline $\begin{array}{l}\text { Horeca } \\
\text { Reparatie } \\
\text { Zakelijke dienstverlening } \\
\text { Overige commerciële dienstverlening }\end{array}$ & $\begin{array}{r}6 \\
48 \\
6 \\
17\end{array}$ & $\begin{array}{l}\text { laag } \\
\text { erg hoog } \\
\text { laag } \\
\text { gemiddeld }\end{array}$ \\
\hline Kwartaire diensten & 5 & laag \\
\hline $\begin{array}{l}\text { Gezondheidszorg } \\
\text { Overige kwartaire diensten }\end{array}$ & $\begin{array}{l}5 \\
7\end{array}$ & $\begin{array}{l}\text { laag } \\
\text { laag }\end{array}$ \\
\hline
\end{tabular}


Tabel 2.2 (vervolg)

Percentage werknemers dat gebruik maakt van gereedschap of apparaten die trilling veroorzaken, naar bedrijfssector, 1996

Bedrijfssector

Overheid en onderwijs

Onderwijs

Overheid

Bron: CBS/ROA typering

laag

erg laag

laag 
Tabel 2.3

Percentage werknemers dat kracht moet zetten tijdens het werk, naar bedrijfssector, 1996

\begin{tabular}{|c|c|c|}
\hline Bedrijfssector & $\%$ & typering \\
\hline Landbouw en visserij & 62 & erg hoog \\
\hline $\begin{array}{l}\text { Tuinbouw } \\
\text { Veehouderij } \\
\text { Akkerbouw, bosbouw en visserij }\end{array}$ & $\begin{array}{r}61 \\
63 \\
-\end{array}$ & $\begin{array}{l}\text { hoog } \\
\text { erg hoog } \\
\text { erg hoog }\end{array}$ \\
\hline Voeding & 48 & hoog \\
\hline $\begin{array}{l}\text { Vlees- en visverwerking } \\
\text { Overige voedingsproducten } \\
\text { Drank en tabaksproducten }\end{array}$ & $\begin{array}{l}62 \\
45 \\
36\end{array}$ & $\begin{array}{l}\text { erg hoog } \\
\text { gemiddeld } \\
\text { gemiddeld }\end{array}$ \\
\hline Chemie & 35 & gemiddeld \\
\hline $\begin{array}{l}\text { Basischemie } \\
\text { Eindproducten chemie } \\
\text { Kunststofverwerking }\end{array}$ & $\begin{array}{l}34 \\
27 \\
47\end{array}$ & $\begin{array}{l}\text { gemiddeld } \\
\text { gemiddeld } \\
\text { gemiddeld }\end{array}$ \\
\hline Metaal en elektrotechniek & 41 & gemiddeld \\
\hline $\begin{array}{l}\text { Basismetaal } \\
\text { Metaalproducten } \\
\text { Machine-industrie } \\
\text { Elektrotechniek } \\
\text { Transportmiddelen }\end{array}$ & $\begin{array}{l}44 \\
50 \\
44 \\
18 \\
47\end{array}$ & $\begin{array}{l}\text { gemiddeld } \\
\text { hoog } \\
\text { gemiddeld } \\
\text { laag } \\
\text { gemiddeld }\end{array}$ \\
\hline Overige industrie & 37 & gemiddeld \\
\hline $\begin{array}{l}\text { Textiel } \\
\text { Hout- en bouwmaterialen } \\
\text { Papier } \\
\text { Grafische industrie }\end{array}$ & $\begin{array}{l}42 \\
53 \\
42 \\
25\end{array}$ & $\begin{array}{l}\text { gemiddeld } \\
\text { hoog } \\
\text { gemiddeld } \\
\text { laag }\end{array}$ \\
\hline Energie & 24 & laag \\
\hline Bouw en onroerend goed & 62 & erg hoog \\
\hline $\begin{array}{l}\text { Bouw } \\
\text { Exploitatie van onroerend goed }\end{array}$ & $\begin{array}{l}68 \\
13\end{array}$ & $\begin{array}{l}\text { erg hoog } \\
\text { erg laag }\end{array}$ \\
\hline Handel & 41 & gemiddeld \\
\hline Transport en communicatie & 36 & gemiddeld \\
\hline $\begin{array}{l}\text { Scheep- en luchtvaart } \\
\text { Weg- en railvervoer } \\
\text { Communicatie }\end{array}$ & $\begin{array}{l}41 \\
37 \\
32\end{array}$ & $\begin{array}{l}\text { gemiddeld } \\
\text { gemiddeld } \\
\text { gemiddeld }\end{array}$ \\
\hline Bank- en verzekeringswezen & 3 & erg laag \\
\hline $\begin{array}{l}\text { Bankwezen } \\
\text { Verzekeringswezen }\end{array}$ & - & $\begin{array}{l}\text { erg laag } \\
\text { erg laag }\end{array}$ \\
\hline Horeca, reparatie en zakelijke dienstverlening & 28 & gemiddeld \\
\hline $\begin{array}{l}\text { Horeca } \\
\text { Reparatie } \\
\text { Zakelijke dienstverlening } \\
\text { Overige commerciële dienstverlening }\end{array}$ & $\begin{array}{l}50 \\
57 \\
17 \\
37\end{array}$ & $\begin{array}{l}\text { hoog } \\
\text { hoog } \\
\text { laag } \\
\text { gemiddeld }\end{array}$ \\
\hline Kwartaire diensten & 45 & gemiddeld \\
\hline $\begin{array}{l}\text { Gezondheidszorg } \\
\text { Overige kwartaire diensten }\end{array}$ & $\begin{array}{l}49 \\
23\end{array}$ & $\begin{array}{l}\text { hoog } \\
\text { laag }\end{array}$ \\
\hline
\end{tabular}


Tabel 2.3 (vervolg)

Percentage werknemers dat kracht moet zetten tijdens het werk, naar bedrijfssector, 1996

\begin{tabular}{lcl}
\hline Bedrijfssector & $\%$ & typering \\
\hline Overheid en onderwijs & 14 & erg laag \\
Onderwijs & 11 & erg laag \\
Overheid & 16 & laag \\
\hline Bron: CBS/ROA & & 16 \\
\hline
\end{tabular}

Bron: CBS/ROA 
Tabel 2.4

Percentage werknemers dat werkzaam is in ploegendienst, naar bedrijfssector, 1996

\begin{tabular}{|c|c|c|}
\hline Bedrijfssector & $\%$ & typering \\
\hline Landbouw en visserij & - & laag \\
\hline $\begin{array}{l}\text { Tuinbouw } \\
\text { Veehouderij } \\
\text { Akkerbouw, bosbouw en visserij }\end{array}$ & $\begin{array}{l}- \\
-\end{array}$ & $\begin{array}{l}\text { erg laag } \\
\text { laag } \\
\text { laag }\end{array}$ \\
\hline Voeding & 29 & hoog \\
\hline $\begin{array}{l}\text { Vlees- en visverwerking } \\
\text { Overige voedingsproducten } \\
\text { Drank en tabaksproducten }\end{array}$ & $\begin{array}{l}16 \\
31 \\
39\end{array}$ & $\begin{array}{l}\text { gemiddeld } \\
\text { hoog } \\
\text { erg hoog }\end{array}$ \\
\hline Chemie & 32 & hoog \\
\hline $\begin{array}{l}\text { Basischemie } \\
\text { Eindproducten chemie } \\
\text { Kunststofverwerking }\end{array}$ & $\begin{array}{l}41 \\
19 \\
38\end{array}$ & $\begin{array}{l}\text { erg hoog } \\
\text { gemiddeld } \\
\text { hoog }\end{array}$ \\
\hline Metaal en elektrotechniek & 15 & gemiddeld \\
\hline $\begin{array}{l}\text { Basismetaal } \\
\text { Metaalproducten } \\
\text { Machine-industrie } \\
\text { Elektrotechniek } \\
\text { Transportmiddelen }\end{array}$ & $\begin{array}{r}49 \\
9 \\
6 \\
17 \\
22\end{array}$ & $\begin{array}{l}\text { erg hoog } \\
\text { gemiddeld } \\
\text { gemiddeld } \\
\text { gemiddeld } \\
\text { hoog }\end{array}$ \\
\hline Overige industrie & 22 & hoog \\
\hline $\begin{array}{l}\text { Textiel } \\
\text { Hout- en bouwmaterialen } \\
\text { Papier } \\
\text { Grafische industrie }\end{array}$ & $\begin{array}{l}17 \\
19 \\
45 \\
18\end{array}$ & $\begin{array}{l}\text { gemiddeld } \\
\text { gemiddeld } \\
\text { erg hoog } \\
\text { gemiddeld }\end{array}$ \\
\hline Energie & 14 & gemiddeld \\
\hline Bouw en onroerend goed & - & erg laag \\
\hline $\begin{array}{l}\text { Bouw } \\
\text { Exploitatie van onroerend goed }\end{array}$ & - & $\begin{array}{l}\text { erg laag } \\
\text { laag }\end{array}$ \\
\hline Handel & 4 & laag \\
\hline Transport en communicatie & 21 & hoog \\
\hline $\begin{array}{l}\text { Handel } \\
\text { Scheep- en luchtvaart } \\
\text { Weg- en railvervoer } \\
\text { Communicatie }\end{array}$ & $\begin{array}{r}4 \\
33 \\
22 \\
13\end{array}$ & $\begin{array}{l}\text { laag } \\
\text { hoog } \\
\text { hoog } \\
\text { gemiddeld }\end{array}$ \\
\hline Bank- en verzekeringswezen & - & laag \\
\hline $\begin{array}{l}\text { Bankwezen } \\
\text { Verzekeringswezen }\end{array}$ & - & $\begin{array}{l}\text { laag } \\
\text { erg laag }\end{array}$ \\
\hline Horeca, reparatie en zakelijke dienstverlening & 7 & gemiddeld \\
\hline $\begin{array}{l}\text { Horeca } \\
\text { Reparatie } \\
\text { Zakelijke dienstverlening } \\
\text { Overige commerciële dienstverlening }\end{array}$ & $\begin{array}{r}20 \\
- \\
-\end{array}$ & $\begin{array}{l}\text { gemiddeld } \\
\text { laag } \\
\text { gemiddeld } \\
\text { gemiddeld }\end{array}$ \\
\hline Kwartaire diensten & 18 & gemiddeld \\
\hline $\begin{array}{l}\text { Gezondheidszorg } \\
\text { Overige kwartaire diensten }\end{array}$ & $\begin{array}{r}20 \\
5\end{array}$ & $\begin{array}{l}\text { hoog } \\
\text { gemiddeld }\end{array}$ \\
\hline
\end{tabular}


Tabel 2.4 (vervolg)

Percentage werknemers dat werkzaam is in ploegendienst, naar bedrijfssector, 1996

\begin{tabular}{lcc}
\hline Bedrijfssector & $\%$ & typering \\
\hline Overheid en onderwijs & 9 & gemiddeld \\
$\begin{array}{l}\text { Onderwijs } \\
\text { Overheid }\end{array}$ & 11 & $\begin{array}{l}\text { erg laag } \\
\text { gemiddeld }\end{array}$ \\
\hline
\end{tabular}

Bron: CBS/ROA 
Tabel 2.5

Percentage werknemers dat onder hoge tijdsdruk werkt, naar bedrijfssector, 1996

\begin{tabular}{|c|c|c|}
\hline Bedrijfssector & $\%$ & typering \\
\hline Landbouw en visserij & 46 & erg laag \\
\hline $\begin{array}{l}\text { Tuinbouw } \\
\text { Veehouderij } \\
\text { Akkerbouw, bosbouw en visserij }\end{array}$ & $\begin{array}{r}45 \\
46 \\
-\end{array}$ & $\begin{array}{l}\text { erg laag } \\
\text { erg laag } \\
\text { laag }\end{array}$ \\
\hline Voeding & 62 & gemiddeld \\
\hline $\begin{array}{l}\text { Vlees- en visverwerking } \\
\text { Overige voedingsproducten } \\
\text { Drank en tabaksproducten }\end{array}$ & $\begin{array}{l}65 \\
61 \\
61\end{array}$ & $\begin{array}{l}\text { hoog } \\
\text { gemiddeld } \\
\text { gemiddeld }\end{array}$ \\
\hline Chemie & 63 & gemiddeld \\
\hline $\begin{array}{l}\text { Basischemie } \\
\text { Eindproducten chemie } \\
\text { Kunststofverwerking }\end{array}$ & $\begin{array}{l}67 \\
63 \\
59\end{array}$ & $\begin{array}{l}\text { hoog } \\
\text { gemiddeld } \\
\text { gemiddeld }\end{array}$ \\
\hline Metaal en elektrotechniek & 57 & laag \\
\hline $\begin{array}{l}\text { Basismetaal } \\
\text { Metaalproducten } \\
\text { Machine-industrie } \\
\text { Elektrotechniek } \\
\text { Transportmiddelen }\end{array}$ & $\begin{array}{l}59 \\
49 \\
63 \\
62 \\
64\end{array}$ & $\begin{array}{l}\text { gemiddeld } \\
\text { erg laag } \\
\text { gemiddeld } \\
\text { gemiddeld } \\
\text { gemiddeld }\end{array}$ \\
\hline Overige industrie & 62 & hoog \\
\hline $\begin{array}{l}\text { Textiel } \\
\text { Hout- en bouwmaterialen } \\
\text { Papier } \\
\text { Grafische industrie }\end{array}$ & $\begin{array}{l}57 \\
57 \\
64 \\
73\end{array}$ & $\begin{array}{l}\text { laag } \\
\text { laag } \\
\text { gemiddeld } \\
\text { erg hoog }\end{array}$ \\
\hline Energie & 64 & gemiddeld \\
\hline Bouw en onroerend goed & 57 & gemiddeld \\
\hline $\begin{array}{l}\text { Bouw } \\
\text { Exploitatie van onroerend goed }\end{array}$ & $\begin{array}{l}57 \\
57\end{array}$ & $\begin{array}{l}\text { gemiddeld } \\
\text { laag }\end{array}$ \\
\hline Handel & 54 & laag \\
\hline Transport en communicatie & 69 & hoog \\
\hline $\begin{array}{l}\text { Scheep- en luchtvaart } \\
\text { Weg- en railvervoer } \\
\text { Communicatie }\end{array}$ & $\begin{array}{l}79 \\
67 \\
69\end{array}$ & $\begin{array}{l}\text { erg hoog } \\
\text { hoog } \\
\text { hoog }\end{array}$ \\
\hline Bank- en verzekeringswezen & 66 & hoog \\
\hline $\begin{array}{l}\text { Bankwezen } \\
\text { Verzekeringswezen }\end{array}$ & $\begin{array}{l}69 \\
61\end{array}$ & $\begin{array}{l}\text { erg hoog } \\
\text { gemiddeld }\end{array}$ \\
\hline Horeca, reparatie en zakelijke dienstverlening & 66 & hoog \\
\hline $\begin{array}{l}\text { Horeca } \\
\text { Reparatie } \\
\text { Zakelijke dienstverlening } \\
\text { Overige commerciële dienstverlening }\end{array}$ & $\begin{array}{l}67 \\
54 \\
71 \\
49\end{array}$ & $\begin{array}{l}\text { hoog } \\
\text { laag } \\
\text { erg hoog } \\
\text { erg laag }\end{array}$ \\
\hline Kwartaire diensten & 63 & gemiddeld \\
\hline $\begin{array}{l}\text { Gezondheidszorg } \\
\text { Overige kwartaire diensten }\end{array}$ & $\begin{array}{l}63 \\
65\end{array}$ & $\begin{array}{l}\text { gemiddeld } \\
\text { gemiddeld }\end{array}$ \\
\hline
\end{tabular}


Tabel 2.5 (vervolg)

Percentage werknemers dat onder hoge tijdsdruk werkt, naar bedrijfssector, 1996

\begin{tabular}{lcc}
\hline Bedrijfssector & $\%$ & typering \\
\hline Overheid en onderwijs & 62 & gemiddeld \\
Onderwijs & 59 & gemiddeld \\
Overheid & 65 & hoog \\
\hline Bron: & & \\
\hline
\end{tabular}

Bron: CBS/ROA 


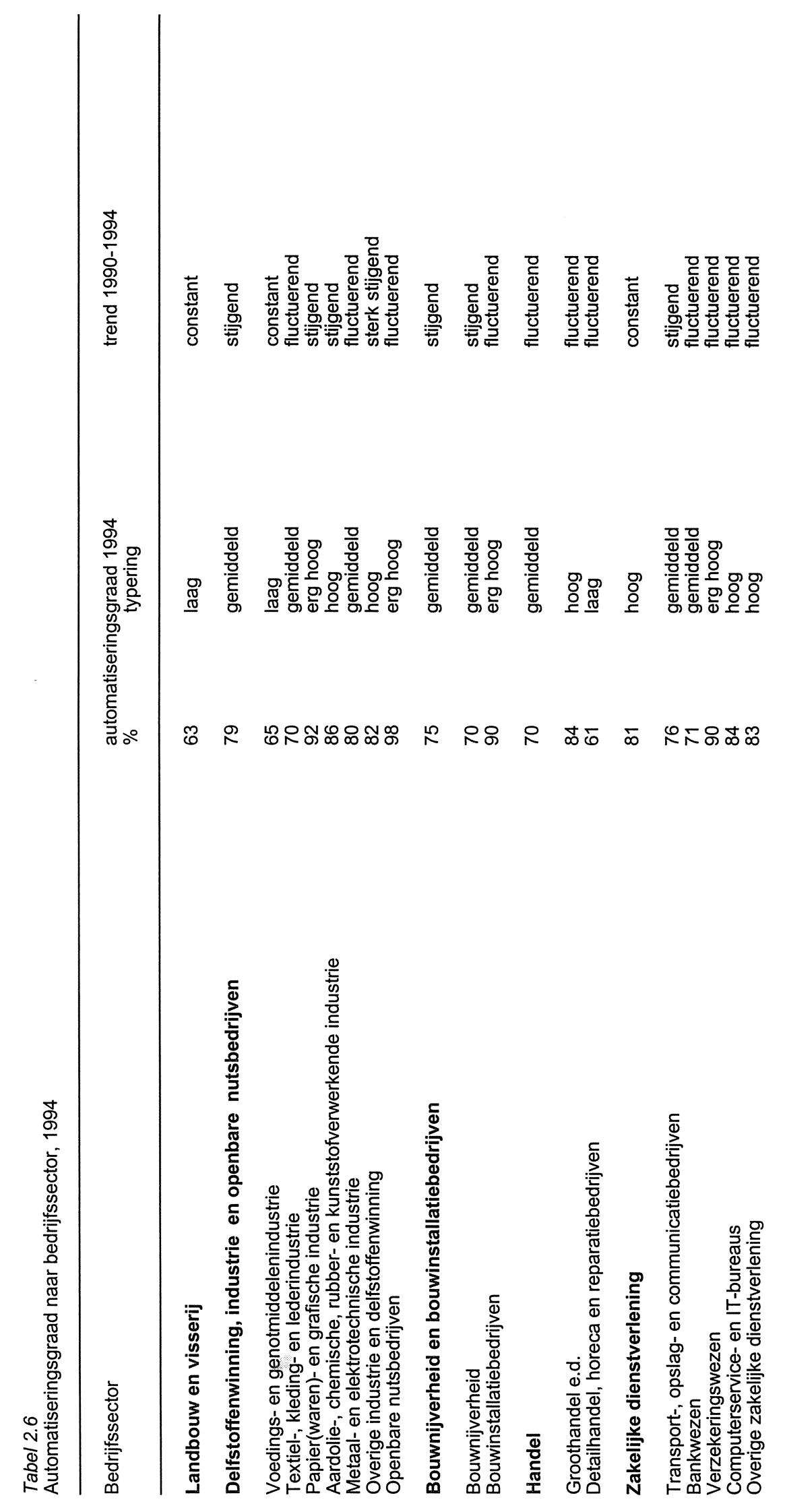




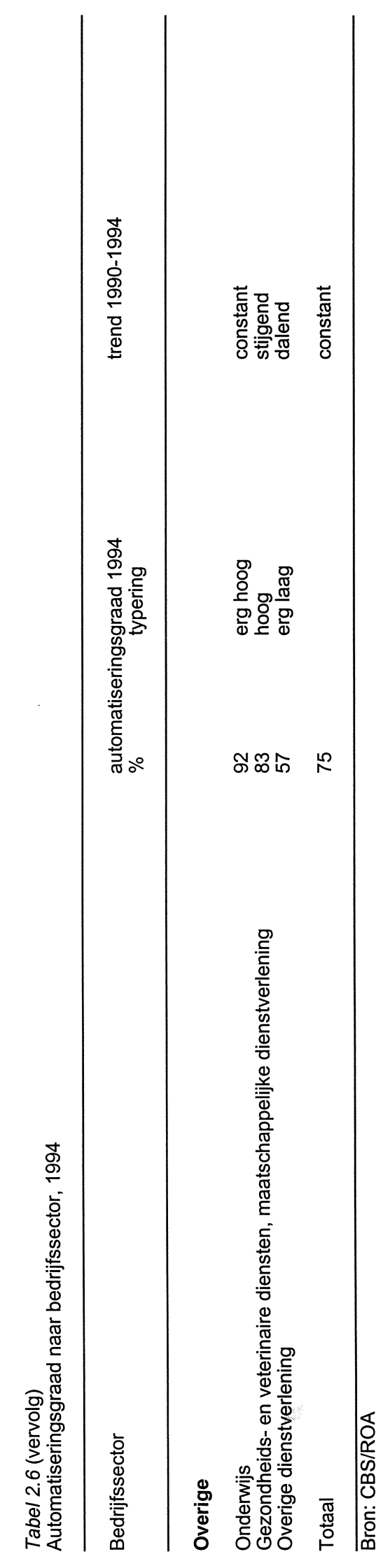




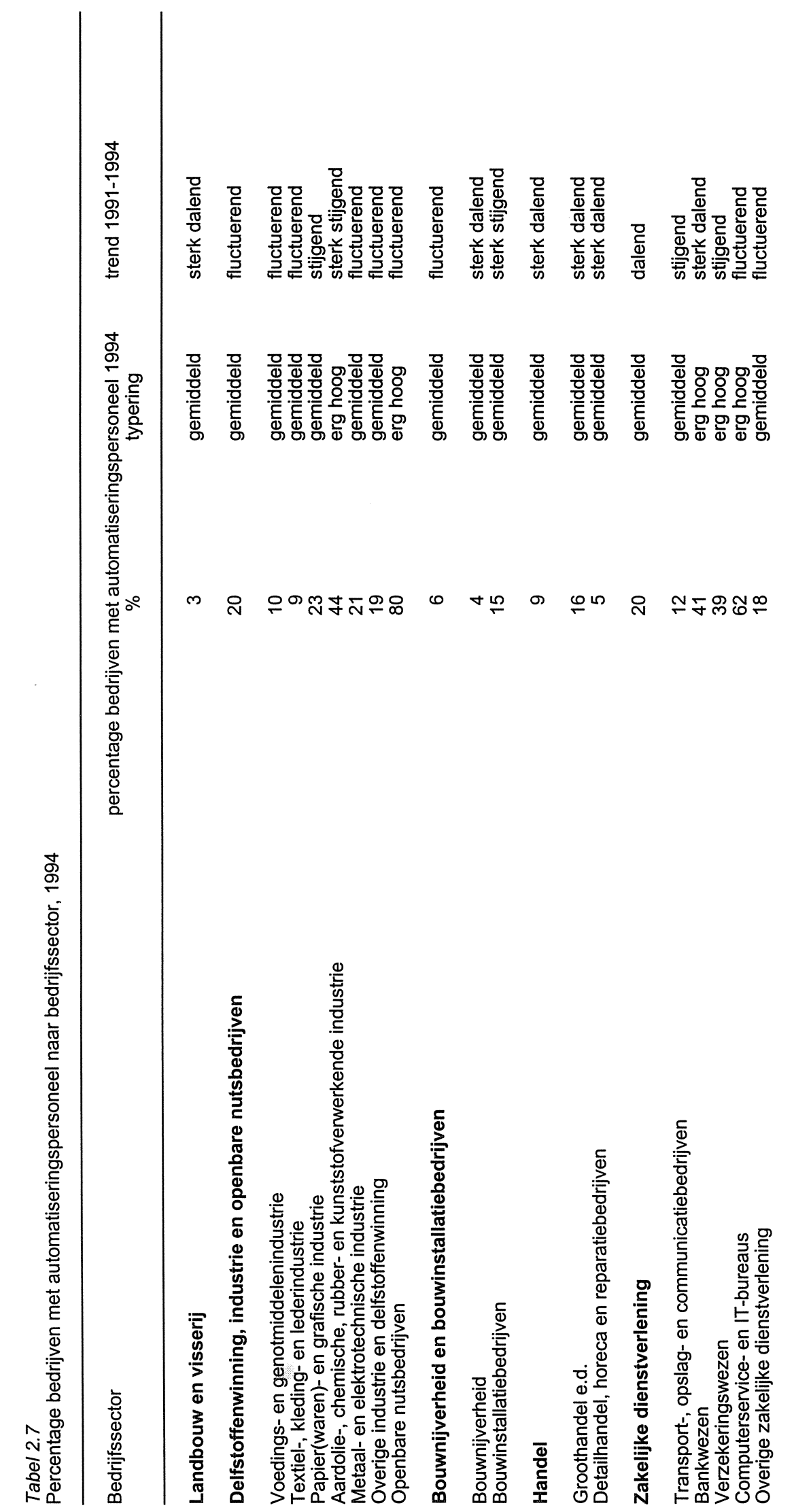




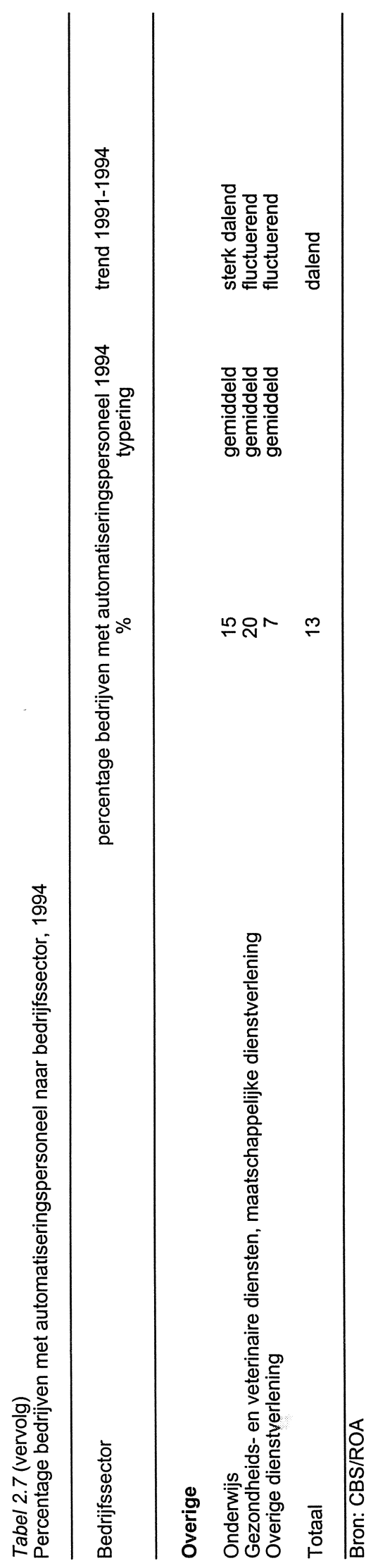




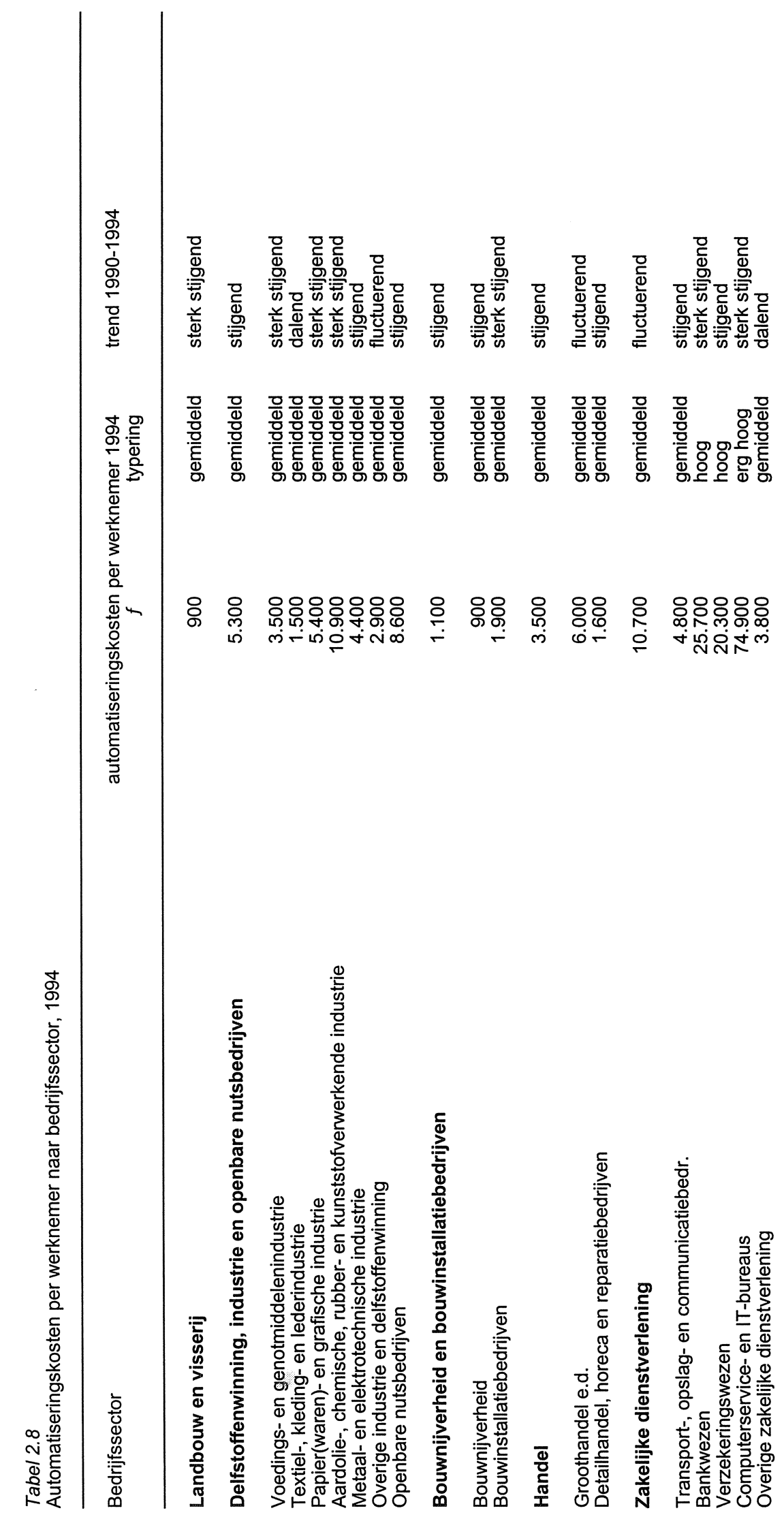




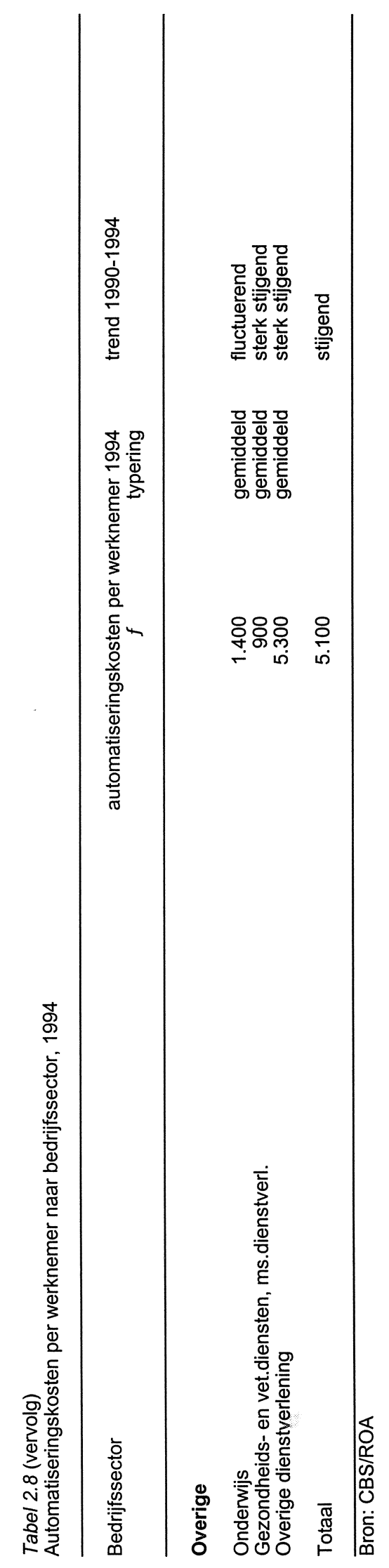


Tabel 2.9

Gemiddelde omvang van de R\&D-activiteiten als percentage van de omzet en het percentage bedrijven met $R \& D$, naar bedrijfssector, 1994

\begin{tabular}{|c|c|c|c|c|}
\hline Bedrijfssector & \multicolumn{2}{|c|}{$\begin{array}{l}\text { gemiddelde omvang } \\
\text { R\&D } \\
\% \text { typering }\end{array}$} & \multicolumn{2}{|c|}{$\begin{array}{l}\text { percentage bedrijven } \\
\text { met R\&D } \\
\% \text { typering }\end{array}$} \\
\hline $\begin{array}{l}\text { Landbouw en visserij } \\
\text { Voedings- en genotmiddelenindustrie } \\
\text { Chemie } \\
\text { Metaal en elektrotechniek } \\
\text { Overige industrie } \\
\text { Energie } \\
\text { Bouw } \\
\text { Handel } \\
\text { Transport, opslag en communicatie } \\
\text { Bank- en verzekeringswezen } \\
\text { Overige commerciële dienstverlening } \\
\text { Kwartaire diensten (excl. zorg) } \\
\text { Overheid }\end{array}$ & $\begin{array}{r}6 \\
7 \\
7 \\
7 \\
3 \\
5 \\
2 \\
2 \\
21 \\
3 \\
2 \\
12\end{array}$ & $\begin{array}{l}\text { gemiddeld } \\
\text { hoog } \\
\text { hoog } \\
\text { hoog } \\
\text { gemiddeld } \\
\text { gemiddeld } \\
\text { gemiddeld } \\
\text { gemiddeld } \\
\text { erg hoog } \\
\text { gemiddeld } \\
\text { gemiddeld } \\
\text { erg hoog } \\
\text { - }\end{array}$ & $\begin{array}{l}35 \\
54 \\
68 \\
44 \\
34 \\
28 \\
20 \\
24 \\
15 \\
27 \\
27 \\
63\end{array}$ & $\begin{array}{l}\text { gemiddeld } \\
\text { erg hoog } \\
\text { erg hoog } \\
\text { hoog } \\
\text { gemiddeld } \\
\text { gemiddeld } \\
\text { laag } \\
\text { gemiddeld } \\
\text { laag } \\
\text { gemiddeld } \\
\text { gemiddeld } \\
\text { erg hoog } \\
-\end{array}$ \\
\hline Totaal & 4 & & 29 & \\
\hline
\end{tabular}

Tabel 2.10

Percentage R\&D voor vernieuwing van producten en diensten en voor vernieuwing van productieprocessen, naar bedrijfssector, 1994

\begin{tabular}{|c|c|c|c|c|}
\hline \multirow{2}{*}{$\begin{array}{l}\text { Bedrijfssector } \\
\text { Landbouw en visserij } \\
\text { Voedings- en genotmiddelenindustrie } \\
\text { Chemie } \\
\text { Metaal en elektrotechniek } \\
\text { Overige industrie } \\
\text { Energie } \\
\text { Bouw } \\
\text { Handel } \\
\text { Transport, opslag en communicatie } \\
\text { Bank-en verzekeringswezen } \\
\text { Overige commerciële dienstverlening } \\
\text { Kwartaire diensten (excl. zorg) } \\
\text { Overheid }\end{array}$} & \multicolumn{2}{|c|}{$\begin{array}{l}\text { vernieuwing } \\
\text { producten en diensten } \\
\% \quad \text { typering }\end{array}$} & \multicolumn{2}{|c|}{$\begin{array}{l}\text { vernieuwing } \\
\text { productieprocessen } \\
\% \quad \text { typering }\end{array}$} \\
\hline & $\begin{array}{l}15 \\
55 \\
42 \\
36 \\
21 \\
17 \\
16 \\
21 \\
16 \\
74 \\
15 \\
45 \\
-\end{array}$ & $\begin{array}{l}\text { erg laag } \\
\text { hoog } \\
\text { gemiddeld } \\
\text { gemiddeld } \\
\text { laag } \\
\text { laag } \\
\text { erg laag } \\
\text { laag } \\
\text { erg laag } \\
\text { erg hoog } \\
\text { erg laag } \\
\text { gemiddeld } \\
-\end{array}$ & $\begin{array}{r}17 \\
20 \\
25 \\
22 \\
19 \\
14 \\
12 \\
48 \\
10 \\
20 \\
7 \\
15 \\
-\end{array}$ & $\begin{array}{l}\text { laag } \\
\text { laag } \\
\text { gemiddeld } \\
\text { gemiddeld } \\
\text { laag } \\
\text { laag } \\
\text { erg laag } \\
\text { erg hoog } \\
\text { erg laag } \\
\text { laag } \\
\text { erg laag } \\
\text { laag } \\
\text { - }\end{array}$ \\
\hline Totaal & 40 & & 71 & \\
\hline
\end{tabular}


Tabel 2.11

Percentage producten/diensten dat in de periode 1992-1994 is vernieuwd, naar bedrijfssector, 1994

\begin{tabular}{lrrrr}
\hline Bedrijfssector & $\begin{array}{l}\text { vernieuwing } \\
\text { op enkele aspecten } \\
\text { typering }\end{array}$ & $\begin{array}{l}\text { ingrijpende } \\
\text { vernieuwing } \\
\text { typering }\end{array}$ \\
\hline Landbouw en visserij & 8 & erg laag & 7 & laag \\
Voedings- en genotmiddelenindustrie & 25 & gemiddeld & 28 & erg hoog \\
Chemie & 18 & gemidddeld & 17 & hoog \\
Metaal en elektrotechniek & 17 & laag & 12 & gemiddeld \\
Overige industrie & 17 & laag & 11 & gemiddeld \\
Energie & 4 & erg laag & 5 & laag \\
Bouw & 8 & erg laag & 5 & laag \\
Handel & 17 & laag & 9 & laag \\
Transport, opslag en communicatie & 10 & erg laag & 24 & erg hoog \\
Bank- en verzekeringswezen & 37 & erg hoog & 19 & hoog \\
Overige commerciële dienstverlening & 11 & erg laag & 9 & laag \\
Kwartaire diensten (excl. zorg) & 18 & gemiddeld & 9 & laag \\
Overheid & - & - & - & - \\
Total & 22 & & 13 & \\
\hline
\end{tabular}

Bron: OSA/ROA

Tabel 2.12

Percentage bedrijven waarin sprake is geweest van organisatiewijzigingen in 1992-1994, naar bedrijfsector, 1994

\begin{tabular}{lrlll}
\hline Bedrijfssector & verandering & \multicolumn{2}{l}{ interne } \\
& positie bedrijf & typering & \multicolumn{2}{l}{$\begin{array}{l}\text { reorganisaties } \\
\text { typering }\end{array}$} \\
\hline Landbouw en visserij & 5 & gemiddeld & 14 & laag \\
Voedings- en genotmiddelenindustrie & 8 & gemiddeld & 10 & laag \\
Chemie & 14 & erg hoog & 17 & laag \\
Metaal en elektrotechniek & 8 & gemiddeld & 8 & erg laag \\
Overige industrie & 6 & gemiddeld & 12 & laag \\
Energie & 19 & erg hoog & 17 & laag \\
Bouw & 6 & gemiddeld & 11 & laag \\
Handel & 7 & gemiddeld & 7 & erg laag \\
Transport, opslag en communicatie & 3 & laag & 38 & hoog \\
Bank- en verzekeringswezen & 9 & hoog & 65 & erg hoog \\
Overige commerciële dienstverlening & 5 & gemiddeld & 10 & laag \\
Kwartaire diensten (excl. zorg) & 6 & gemiddeld & 21 & gemiddeld \\
Overheid & 9 & hoog & 26 & gemiddeld \\
Totaal & 6 & & 29 & \\
\hline
\end{tabular}

Bron: OSA/ROA 


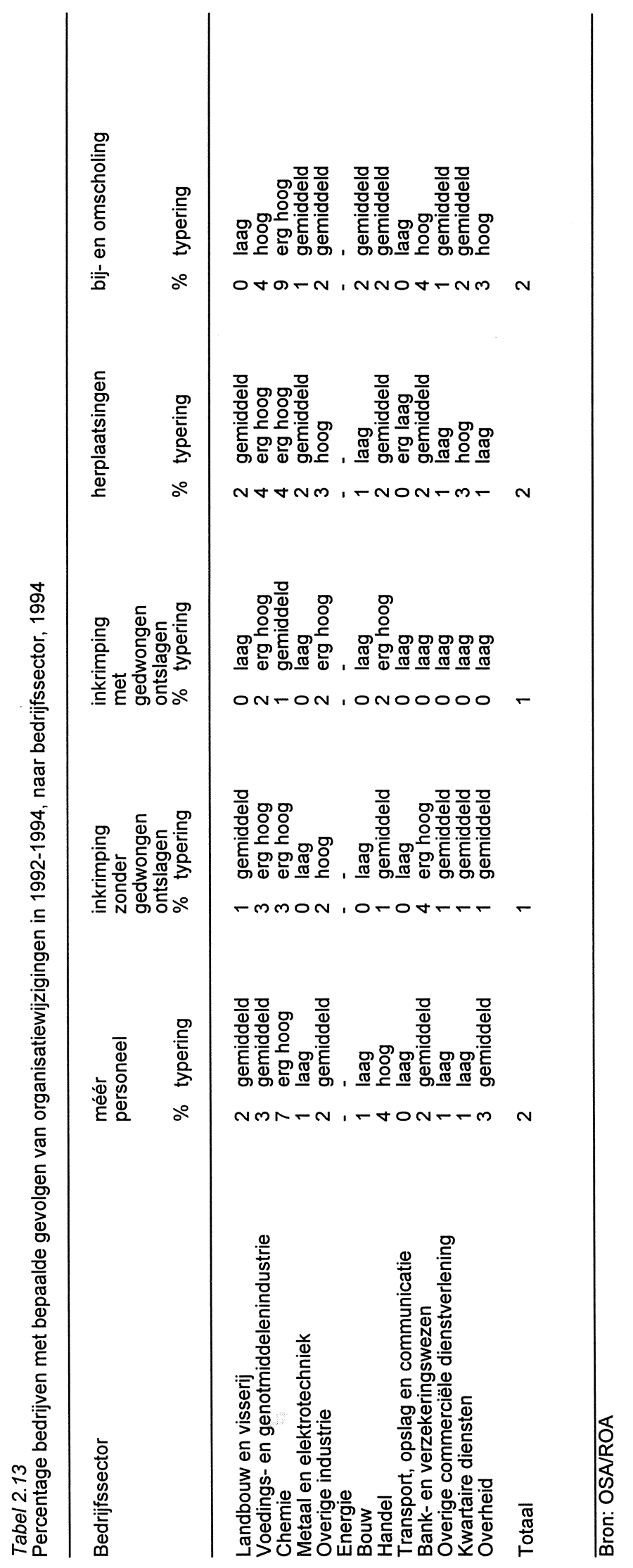


Tabel 2.14

Mate van informatisering naar bedrijfssector, 1996*

\begin{tabular}{|c|c|c|}
\hline Bedrijfssector & $\%$ & typering \\
\hline Landbouw en visserij & 15 & erg laag \\
\hline $\begin{array}{l}\text { Tuinbouw } \\
\text { Veehouderij } \\
\text { Akkerbouw, bosbouw en visserij }\end{array}$ & $\begin{array}{r}13 \\
16 \\
-\end{array}$ & $\begin{array}{l}\text { erg laag } \\
\text { erg laag } \\
\text { laag }\end{array}$ \\
\hline Voeding & 42 & gemiddeld \\
\hline $\begin{array}{l}\text { Vlees- en visverwerking } \\
\text { Overige voedingsproducten } \\
\text { Drank en tabaksproducten }\end{array}$ & $\begin{array}{l}24 \\
44 \\
62\end{array}$ & $\begin{array}{l}\text { laag } \\
\text { gemiddeld } \\
\text { gemiddeld }\end{array}$ \\
\hline Chemie & 70 & hoog \\
\hline $\begin{array}{l}\text { Basischemie } \\
\text { Eindproducten chemie } \\
\text { Kunststofverwerking }\end{array}$ & $\begin{array}{l}83 \\
74 \\
48\end{array}$ & $\begin{array}{l}\text { erg hoog } \\
\text { hoog } \\
\text { gemiddeld }\end{array}$ \\
\hline Metaal en elektrotechniek & 46 & gemiddeld \\
\hline $\begin{array}{l}\text { Basismetaal } \\
\text { Metaalproducten } \\
\text { Machine-industrie } \\
\text { Elektrotechniek } \\
\text { Transportmiddelen }\end{array}$ & $\begin{array}{l}64 \\
30 \\
51 \\
68 \\
46\end{array}$ & $\begin{array}{l}\text { gemiddeld } \\
\text { laag } \\
\text { gemiddeld } \\
\text { hoog } \\
\text { gemiddeld }\end{array}$ \\
\hline Overige industrie & 53 & gemiddeld \\
\hline $\begin{array}{l}\text { Textiel } \\
\text { Hout- en bouwmaterialen } \\
\text { Papier } \\
\text { Grafische industrie }\end{array}$ & $\begin{array}{l}35 \\
38 \\
57 \\
67\end{array}$ & $\begin{array}{l}\text { laag } \\
\text { laag } \\
\text { gemiddeld } \\
\text { gemiddeld }\end{array}$ \\
\hline Energie & 78 & hoog \\
\hline Bouw en onroerend goed & 27 & laag \\
\hline $\begin{array}{l}\text { Bouw } \\
\text { Exploitatie van onroerend goed }\end{array}$ & $\begin{array}{l}22 \\
78\end{array}$ & $\begin{array}{l}\text { erg laag } \\
\text { hoog }\end{array}$ \\
\hline Handel & 50 & gemiddeld \\
\hline Transport en communicatie & 50 & gemiddeld \\
\hline $\begin{array}{l}\text { Scheep- en luchtvaart } \\
\text { Weg- en railvervoer } \\
\text { Communicatie }\end{array}$ & $\begin{array}{l}67 \\
43 \\
61\end{array}$ & $\begin{array}{l}\text { gemiddeld } \\
\text { gemiddeld } \\
\text { gemiddeld }\end{array}$ \\
\hline Bank- en verzekeringswezen & 95 & erg hoog \\
\hline $\begin{array}{l}\text { Bankwezen } \\
\text { Verzekeringswezen }\end{array}$ & $\begin{array}{l}95 \\
94\end{array}$ & $\begin{array}{l}\text { erg hoog } \\
\text { erg hoog }\end{array}$ \\
\hline Horeca, reparatie en zakelijke dienstverlening & 60 & gemiddeld \\
\hline $\begin{array}{l}\text { Horeca } \\
\text { Reparatie } \\
\text { Zakelijke dienstverlening } \\
\text { Overige commerciële dienstverlening }\end{array}$ & $\begin{array}{l}21 \\
51 \\
76 \\
26\end{array}$ & $\begin{array}{l}\text { erg laag } \\
\text { gemiddeld } \\
\text { hoog } \\
\text { laag }\end{array}$ \\
\hline Kwartaire diensten & 47 & gemiddeld \\
\hline $\begin{array}{l}\text { Gezondheidszorg } \\
\text { Overige kwartaire diensten }\end{array}$ & $\begin{array}{l}43 \\
70\end{array}$ & $\begin{array}{l}\text { gemiddeld } \\
\text { hoog }\end{array}$ \\
\hline
\end{tabular}


Tabel 2.14 (vervolg)

Mate van informatisering naar bedrijfssector, 1996

\begin{tabular}{lcc}
\hline Bedrijfssector & $\%$ & typering \\
\hline Overheid en onderwijs & 73 & hoog \\
Onderwijs & 61 & gemiddeld \\
Overheid & 82 & erg hoog \\
\hline Bron: CBS/ROA & &
\end{tabular}

Bron: CBS/ROA

* Onder 'informatisering' wordt verstaan het percentage werknemers dat gewoonlijk of soms met een computer werkt 
Tabel 2.15

Ontwikkeling aantal werkenden 1992-1996 en uitbreidingsvraag 1997-2002, naar bedrijfssector (gemiddelde jaarlijkse percentages)

\begin{tabular}{lccr} 
Bedrijfssector & $\begin{array}{c}\text { aantal werkenden } \\
\text { (gem. 1995/1996) }\end{array}$ & $\begin{array}{c}1992-1996 \\
\%\end{array}$ & $\begin{array}{c}1997-2002 \\
\%\end{array}$ \\
\hline Landbouw en visserij & 228.000 & $-0,8$ & $-1,0$ \\
Voeding & 158.000 & $-1,1$ & 0,4 \\
Chemie & 130.500 & $-1,7$ & 1,7 \\
Metaal en elektrotechniek & 510.500 & $-0,7$ & 1,8 \\
Overige industrie & 209.000 & $-5,1$ & 0,9 \\
Energie & 611.500 & $-1,8$ & $-0,1$ \\
Bouw en onroerend goed & 455.500 & 2,8 & 0,8 \\
Handel & 865.000 & 1,9 & 2,2 \\
Transport en communicatie & 385.500 & 1,0 & 1,5 \\
Bank- en verzekeringswezen & 223.500 & 1,2 & 0,4 \\
Horeca, reparatie en zakelijke dienstverlening & 889.000 & 5,6 & 3,6 \\
Kwartaire diensten & 982.500 & 1,6 & 0,3 \\
Overheid en onderwijs & 909.500 & 1,6 & 1,7 \\
Totaal (incl. sector onbekend) & 6.115 .000 & 1,4 & \\
\hline Bron: CBS/CPB/ROA & & &
\end{tabular}

Bron: CBS/CPB/ROA 
Tabel 2.16

Percentage werkenden dat deelneemt aan bedrijfsopleidingen, naar bedrijfssector, gemiddelde 1995-1996

\begin{tabular}{|c|c|c|c|}
\hline & $\%$ & typering & trend \\
\hline Landbouw en visserij & - & erg laag & fluctuerend \\
\hline $\begin{array}{l}\text { Tuinbouw } \\
\text { Veehouderij } \\
\text { Akkerbouw, bosbouw en visserij }\end{array}$ & $\begin{array}{l}- \\
-\end{array}$ & $\begin{array}{l}\text { erg laag } \\
\text { erg laag } \\
-\end{array}$ & $\begin{array}{l}\text { fluctuerend } \\
\text { fluctuerend } \\
\text { sterk dalend }\end{array}$ \\
\hline Voeding & 5 & gemiddeld & fluctuerend \\
\hline $\begin{array}{l}\text { Vlees- en visverwerking } \\
\text { Overige voedingsproducten } \\
\text { Drank en tabaksproducten }\end{array}$ & $\overline{5}$ & $\begin{array}{l}- \\
\text { gemiddeld }\end{array}$ & $\begin{array}{l}\text { fluctuerend } \\
\text { fluctuerend } \\
\text { fluctuerend }\end{array}$ \\
\hline Chemie & 7 & hoog & sterk stijgend \\
\hline $\begin{array}{l}\text { Basischemie } \\
\text { Eindproducten chemie } \\
\text { Kunststofverwerking }\end{array}$ & $\begin{array}{r}10 \\
6 \\
-\end{array}$ & $\begin{array}{l}\text { erg hoog } \\
\text { hoog } \\
\text { gemiddeld }\end{array}$ & $\begin{array}{l}\text { sterk stijgend } \\
\text { sterk stijgend } \\
\text { fluctuerend }\end{array}$ \\
\hline Metaal en elektrotechniek & 4 & gemiddeld & fluctuerend \\
\hline $\begin{array}{l}\text { Basismetaal } \\
\text { Metaalproducten } \\
\text { Machine-industrie } \\
\text { Elektrotechniek } \\
\text { Transportmiddelen }\end{array}$ & $\begin{array}{l}9 \\
3 \\
4 \\
7 \\
-\end{array}$ & $\begin{array}{l}\text { hoog } \\
\text { laag } \\
\text { gemiddeld } \\
\text { hoog } \\
\text { laag }\end{array}$ & $\begin{array}{l}\text { sterk stijgend } \\
\text { sterk dalend } \\
\text { sterk stijgend } \\
\text { fluctuerend } \\
\text { sterk dalend }\end{array}$ \\
\hline Overige industrie & 4 & gemiddeld & sterk dalend \\
\hline $\begin{array}{l}\text { Textiel } \\
\text { Hout-en bouwmaterialen } \\
\text { Papier } \\
\text { Grafische industrie }\end{array}$ & $\begin{array}{l}- \\
5 \\
4\end{array}$ & $\begin{array}{l}\text { gemiddeld } \\
\text { gemiddeld }\end{array}$ & $\begin{array}{l}\text { fluctuerend } \\
\text { fluctuerend } \\
\text { sterk dalend } \\
\text { fluctuerend }\end{array}$ \\
\hline Energie & 11 & erg hoog & fluctuerend \\
\hline Bouw en onroerend goed & 6 & gemiddeld & sterk stijgend \\
\hline $\begin{array}{l}\text { Bouw } \\
\text { Exploitatie van onroerend goed }\end{array}$ & 5 & $\begin{array}{l}\text { gemiddeld } \\
\text { gemiddeld }\end{array}$ & $\begin{array}{l}\text { sterk stijgend } \\
\text { fluctuerend }\end{array}$ \\
\hline Handel & 3 & gemiddeld & fluctuerend \\
\hline Transport en communicatie & 3 & gemiddeld & fluctuerend \\
\hline $\begin{array}{l}\text { Scheep- en luchtvaart } \\
\text { Weg- en railvervoer } \\
\text { Communicatie }\end{array}$ & $\begin{array}{l}8 \\
3 \\
3\end{array}$ & $\begin{array}{l}\text { hoog } \\
\text { laag } \\
\text { gemiddeld }\end{array}$ & $\begin{array}{l}\text { sterk stijgend } \\
\text { fluctuerend } \\
\text { sterk dalend }\end{array}$ \\
\hline Bank- en verzekeringswezen & 12 & erg hoog & fluctuerend \\
\hline $\begin{array}{l}\text { Bankwezen } \\
\text { Verzekeringswezen }\end{array}$ & $\begin{array}{r}15 \\
6\end{array}$ & $\begin{array}{l}\text { erg hoog } \\
\text { hoog }\end{array}$ & $\begin{array}{l}\text { stijgend } \\
\text { fluctuerend }\end{array}$ \\
\hline $\begin{array}{l}\text { Horeca, reparatie en zakelijke } \\
\text { dienstverlening }\end{array}$ & 3 & gemiddeld & fluctuerend \\
\hline $\begin{array}{l}\text { Horeca } \\
\text { Reparatie } \\
\text { Zakelijke dienstverlening } \\
\text { Overige commerciële dienstverlening }\end{array}$ & $\begin{array}{l}2 \\
6 \\
4 \\
3\end{array}$ & $\begin{array}{l}\text { laag } \\
\text { gemiddeld } \\
\text { gemiddeld } \\
\text { laag }\end{array}$ & $\begin{array}{l}\text { fluctuerend } \\
\text { fluctuerend } \\
\text { fluctuerend } \\
\text { fluctuerend }\end{array}$ \\
\hline
\end{tabular}


Tabel 2.16 (vervolg)

Percentage werkenden dat deelneemt aan bedrijfsopleidingen, naar bedrijfssector, gemiddelde 1995-1996

\begin{tabular}{llll}
\hline & $\%$ & typering & trend \\
\hline Kwartaire diensten & 5 & gemiddeld & constant \\
Gezondheidszorg & 6 & gemiddeld & gemiddeld \\
Overige kwartaire diensten & 3 & laag & fluctuerend \\
Overheid en onderwijs & 6 & gemiddeld & fluctuerend \\
Onderwijs & 4 & gemiddeld & fluctuerend \\
Overheid & 7 & hoog & fluctuerend \\
Bron: CBS/ROA & & &
\end{tabular}

Bron: CBS/ROA 
Tabel 2.17

Employability-indicatoren naar bedrijfssector, 1996

\begin{tabular}{|c|c|c|c|c|}
\hline Bedrijfssector & $\begin{array}{c}\text { niet } \\
\text { mobiel } \\
\%\end{array}$ & $\begin{array}{l}\text { niet actief } \\
\text { zoekend } \\
\%\end{array}$ & $\begin{array}{c}\text { niet breed } \\
\text { inzetbaar } \\
\%\end{array}$ & $\begin{array}{c}\text { ervarings- } \\
\text { concentratie } \\
\%\end{array}$ \\
\hline Landbouw en visserij & 66 & 94 & 17 & 20 \\
\hline Tuinbouw & - & - & - & - \\
\hline Veehouderij & 67 & 94 & 18 & 21 \\
\hline Akkerbouw, bosbouw en visserij & - & - & - & - \\
\hline Voeding & - & - & - & - \\
\hline Vlees- en visverwerking & - & - & - & - \\
\hline Overige voedingsproducten & - & - & - & - \\
\hline Drank en tabaksproducten & - & - & - & - \\
\hline Chemie & 75 & 91 & 13 & 33 \\
\hline Basischemie & - & - & - & - \\
\hline Eindproducten chemie & - & - & - & - \\
\hline Kunststofverwerking & 74 & 91 & 13 & 35 \\
\hline Metaal en elektrotechniek & 75 & 89 & 21 & 24 \\
\hline Basismetaal & 73 & 94 & 30 & 32 \\
\hline Metaalproducten & 67 & 93 & 17 & 17 \\
\hline Machine-industrie & 78 & 89 & 26 & 30 \\
\hline Elektrotechniek & 72 & 87 & 13 & 28 \\
\hline Transportmiddelen & 80 & 85 & 18 & 17 \\
\hline Overige industrie & 82 & 92 & 24 & 15 \\
\hline Textiel & - & - & - & - \\
\hline Hout- en bouwmaterialen & 78 & 92 & 26 & 11 \\
\hline Papier & 100 & 93 & 33 & 33 \\
\hline Grafische industrie & - & - & - & - \\
\hline Energie & 78 & 95 & 23 & 28 \\
\hline Bouw en onroerend goed & - & - & - & - \\
\hline Bouw & & & & \\
\hline Exploitatie van onroerend goed & - & - & - & - \\
\hline Handel & 70 & 89 & 26 & 24 \\
\hline Transport en communicatie & 69 & 86 & 23 & 23 \\
\hline Scheep- en luchtvaart & 69 & 87 & 23 & 23 \\
\hline Weg- en railvervoer & - & - & - & - \\
\hline Communicatie & - & - & - & - \\
\hline Bank- en verzekeringswezen & 77 & 91 & 27 & 19 \\
\hline Bankwezen & 77 & 89 & 27 & 19 \\
\hline Verzekeringswezen & 76 & 92 & 28 & 19 \\
\hline $\begin{array}{l}\text { Horeca, reparatie en zakelijke } \\
\text { dienstverlening }\end{array}$ & 76 & 91 & 31 & 26 \\
\hline Horeca & - & - & - & - \\
\hline Reparatie & - & - & - & - \\
\hline Zakelijke dienstverlening & 77 & 91 & 33 & 39 \\
\hline Overige commerciële dienstverlening & 76 & 91 & 31 & 25 \\
\hline
\end{tabular}


Tabel 2.17 (vervolg)

Employability-indicatoren naar bedrijfssector, 1996

\begin{tabular}{lcccc}
\hline Bedrijfssector & $\begin{array}{c}\text { niet } \\
\text { mobiel } \\
\%\end{array}$ & $\begin{array}{c}\text { niet actief } \\
\text { zoekend } \\
\%\end{array}$ & $\begin{array}{c}\text { niet breed } \\
\text { inzetbaar } \\
\%\end{array}$ & $\begin{array}{c}\text { ervarings- } \\
\text { concentratie } \\
\%\end{array}$ \\
\hline Kwartaire diensten & 83 & 97 & 36 & 46 \\
$\begin{array}{l}\text { Gezondheidszorg } \\
\text { Overige kwartaire diensten }\end{array}$ & - & -- & 35 & 49 \\
$\begin{array}{l}\text { Overheid en onderwijs } \\
\text { Overheid }\end{array}$ & 85 & 97 & - & - \\
Onderwijs & - & - & - & - \\
\hline Bron: OSA ROA & - & - & - & - \\
\hline
\end{tabular}

Bron: OSA/ROA 


\section{RISICOPROFIELEN NAAR BEDRIJFSSECTOR}




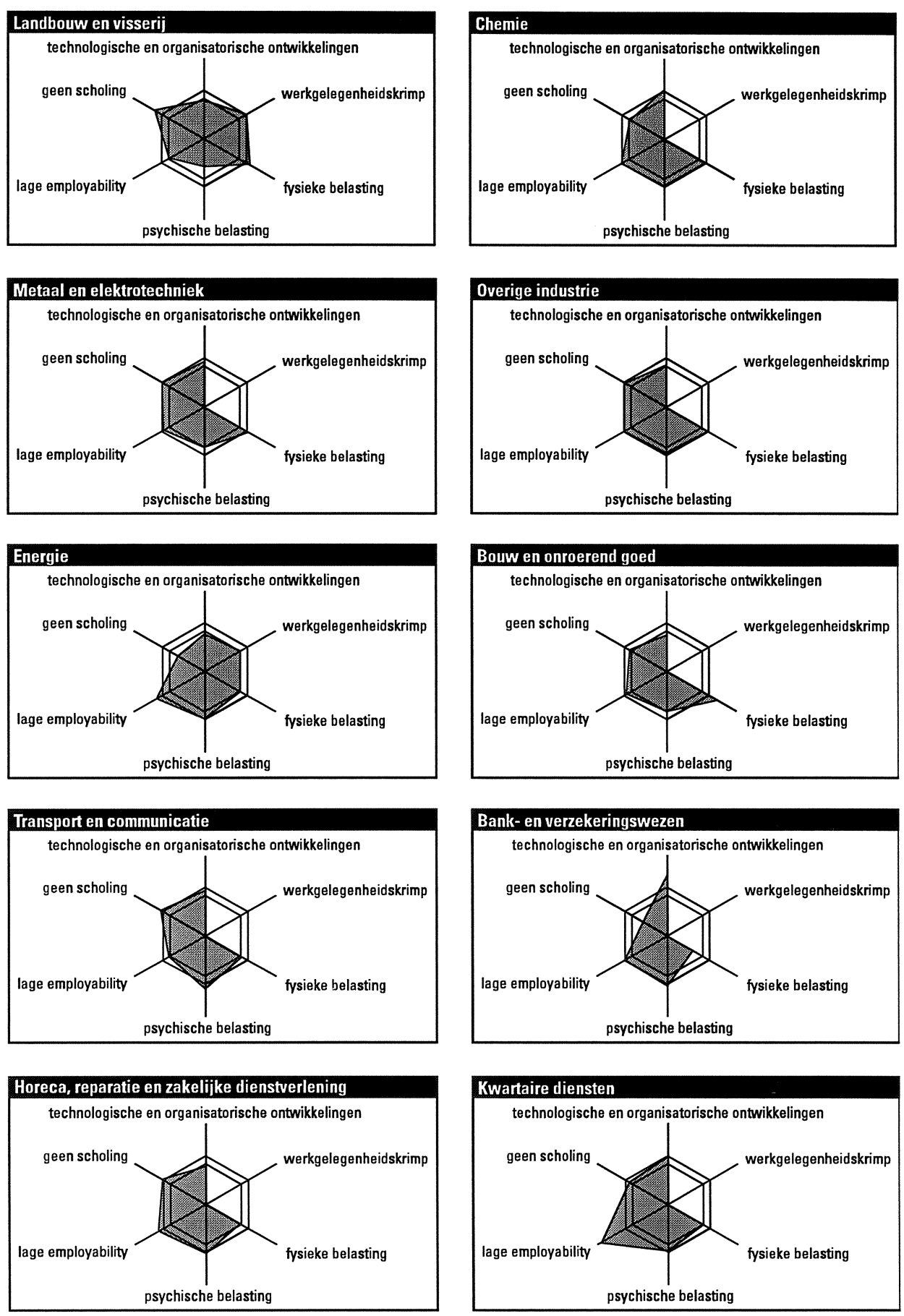

INFORMATIE OVER BEROEPEN 

Tabel 3.1

Percentage werknemers dat geconfronteerd wordt met lawaai tijdens het werk, naar beroepsgroep, 1996

PEDAGOGISCHE BEROEPEN

Leraar basisonderwijs

Docenten exacte, medische en verzorgende vakken ( $2 \mathrm{e}$ graads)

Docenten exacte, medische en verzorgende vakken (1e graads)

Docenten landbouw en techniek (2e graads)

Docenten landbouw en techniek (1e graads)

Docenten economisch-administratieve vakken ( $2 \mathrm{e}$ graads)

Docenten economisch-administratieve vakken (1e graads)

Docenten talen en expressie

Docenten letteren (1e graads)

Docenten sociale vakken (2e graads)

Docenten sociale vakken (1e graads)

Docenten 2 e graads zonder specialisatie

Docent 1 e graads zonder specialisatie

Onderwijskundig medewerkers

Onderwijskundigen en pedagogen

Rij-instructeurs

Zweminstructeurs

Sportinstructeurs

$\% \quad$ typering

\section{CULTURELE BEROEPEN}

Tolken, vertalers en schrijvers

Bibliotheekassistenten

Bibliothecarissen

Grafisch ontwerpers

Kunstenaars

Geestelijk verzorgers

Geestelijken

Journalisten

Taalkundigen

$\begin{aligned} 33 & \text { hoog } \\ - & \text { gemiddeld } \\ - & \text { gemiddeld } \\ 35 & \text { hoog } \\ - & \text { gemiddeld } \\ - & \text { gemiddeld } \\ - & \text { laag } \\ 29 & \text { hoog } \\ - & \text { gemiddeld } \\ 45 & \text { hoog } \\ - & \text { gemiddeld } \\ - & \text { hoog } \\ - & \text { hoog } \\ - & \text { laag } \\ - & \text { laag } \\ - & \text { laag } \\ - & \text { erg hoog } \\ - & \text { hoog }\end{aligned}$

\section{AGRARISCHE BEROEPEN}

Agrarische hulparbeiders

Agrarische arbeiders

Agrarische vakkrachten

Milieuhygiënisten en agrarisch vertegenwoordigers

Landbouwkundigen

Landbouwmachinebestuurders en vissers

Agrarische bedrijfshoofden

laag

laag

erg laag

erg laag

gemiddeld

erg laag

erg laag

laag

erg laag

\section{TECHNISCHE EN INDUSTRIEBEROEPEN}

Productiemedewerkers

Laboratorium-assistenten

Laboranten

Technisch analisten

Natuurwetenschappers

Conciërges

Hoofden technische dienst

Werktuigbouwkundigen

Bouwvakkers

Aannemers en installateurs

Architecten en bouwkundig projectleiders

Weg-en waterbouwkundigen

Weg-en waterbouwkundige arbeiders

Weg-en waterbouwkundige vakkrachten

Weg-en waterbouwkundig ontwerpers en projectleiders

Metaalarbeiders

Bankwerkers en lassers

Bedrijfshoofden metaalbewerking

Assembleurs

Monteurs

Werktuigbouwkundig ontwerpers en hoofden technische dienst

gemiddeld

hoog

gemiddeld

laag

gemiddeld

erg hoog

hoog

erg hoog

hoog

gemiddeld

gemiddeld

gemiddeld

gemiddeld

hoog

gemiddeld

erg hoog

hoog

gemiddeld

laag

erg hoog

erg hoog

gemiddeld

erg hoog

erg hoog

gemiddeld

hoog

erg hoog

gemiddeld 
Tabel 3.1 (vervolg)

Percentage werknemers dat geconfronteerd wordt met lawaai tijdens het werk, naar beroepsgroep, 1996

\begin{tabular}{lcl}
\hline Beroepsgroep & $\%$ & typering \\
\hline Elektronicamonteurs & - & gemiddeld \\
Monteurs en controleurs elektrotechnische producten & 34 & hoog \\
Elektromonteurs & 43 & hoog \\
Elektrotechnisch ontwerpers en bedrijfshoofden & - & gemiddeld \\
Elektrotechnici & - & laag \\
Grafisch productiepersoneel & 36 & hoog \\
Grafische vakkrachten & 49 & hoog \\
Mechanisch operators & 61 & erg hoog \\
Procesoperators & 68 & erg hoog \\
Procestechnologen & - & gemiddeld \\
Materiaalkundigen & $-\overline{\text { gemiddeld }}$ \\
Confectie-arbeiders & 46 & hoog \\
Schoen- en kleermakers & - & gemiddeld
\end{tabular}

Schoen- en kleermakers

gemiddeld

TRANSPORTBEROEPEN

Laders en lossers

Chauffeurs

Schippers en conducteurs

Vliegers, scheepskapiteins en leidinggevenden transport

Stewards

hoog

gemiddeld

erg hoog

hoog

$56 \quad$ erg hoog

\section{MEDISCHE EN PARAMEDISCHE BEROEPEN}

Verpleeghulpen en leerling-verpleegkundigen

Verplegenden en doktersassistenten

Therapeuten en verpleegkundigen

Artsen

Apothekersassistenten en medisch laboranten

Medisch analisten

Apothekers

Afdelingshoofden zorginstelling

gemiddeld gemiddeld

laag

laag

gemiddeld

gemiddeld

laag

laag

\section{ECONOMISCH-ADMINISTRATIEVE BEROEPEN}

Kantoorhulpen, inpakkers en colporteurs

Ondersteunende administratieve hulpkrachten

Bedrijfshoofden

Economen

Productieplanners

Organisatie-adviseurs

Organisatiedeskundigen

Receptionisten en administratieve employés

Boekhouders en secretaresses

Assistent accountants

Accountants

Verzekeringsagenten

Commercieel employés

Commercieel medewerkers

Technisch-commercieel employés

Technisch-bedrijfskundig medewerkers

Juridisch en fiscaal medewerkers

Juridisch, bestuurlijk medewerkers

Juristen

Administratieve transportemployés

Leidinggevenden

Managers

Medisch secretaresses

hoog

hoog

gemiddeld

erg laag

gemiddeld

gemiddeld

erg laag

gemiddeld

laag

erg laag

erg laag

gemiddeld

laag

laag

gemiddeld

gemiddeld

laag

laag

erg laag

gemiddeld

gemiddeld

laag

gemiddeld

\section{INFORMATICABEROEPEN}

Programmeurs

Systeemanalisten

Informatici

Technisch systeemanalisten

laag

erg laag

erg laag 
Tabel 3.1 (vervolg)

Percentage werknemers dat geconfronteerd wordt met lawaai tijdens het werk, naar beroepsgroep, 1996

\section{SOCIAAL-CULTURELE BEROEPEN}

Activiteitenbegeleiders en medewerkers arbeidsbemiddeling Sociaal-cultureel werkers

Sociale raadslieden en hoofden personeelszaken

Sociaal-wetenschappelijk medewerkers

Sociaal-wetenschappelijk onderzoekers

$\begin{aligned} 16 & \text { gemiddeld } \\ 10 & \text { gemiddeld } \\ - & \text { erg laag } \\ - & \text { erg laag } \\ - & \text { erg laag }\end{aligned}$

\section{VERZORGENDE EN DIENSTVERLENENDE BEROEPEN}

Vakkenvullers

Interieurverzorgers

Verkopers

Winkeliers

Hulpkrachten horeca en verzorging

Ziekenverzorgenden

Verzorgend personeel

Café- en snackbarhouders

Bedriifshoofden horeca

Bakkers en slagers

laag

gemiddeld

gemiddeld

laag

gemiddeld

gemiddeld

gemiddeld

gemiddeld

gemiddeld

hoog

\section{OPENBARE ORDE- EN VEILIGHEIDSBEROEPEN}

Adspirant politieagenten, soldaten en beveiligingshulpkrachten

Politieagenten, onderofficieren en beveiligingsemployés

Politie-inspecteurs en officieren

Brandweerlieden

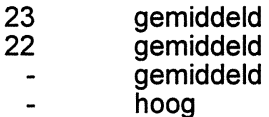

Bron: CBS/ROA 
Tabel 3.2

Percentage werknemers dat geconfronteerd wordt met lawaai tijdens het werk, naar beroepssegment, 1996

\begin{tabular}{|c|c|c|}
\hline Beroepssegment & $\%$ & typering \\
\hline Elementaire beroepen & 33 & hoog \\
\hline Lagere niet-specialistische beroepen & - & hoog \\
\hline Lagere docenten sportvakken & - & erg hoog \\
\hline Lagere agrarische beroepen & 31 & hoog \\
\hline Lagere wiskundige, natuurwetenschappelijke beroepen & - & hoog \\
\hline Lagere technische beroepen & 54 & erg hoog \\
\hline Lagere transportberoepen & 24 & gemiddeld \\
\hline Lagere (para)medische beroepen & - & gemiddeld \\
\hline Lagere administratieve, commerciële beroepen & 10 & gemiddeld \\
\hline Lagere beveiligingsberoepen & 23 & gemiddeld \\
\hline Lagere verzorgende beroepen & 20 & gemiddeld \\
\hline Middelbare docenten transport-, sportvakken & - & gemiddeld \\
\hline Middelbare agrarische beroepen & - & gemiddeld \\
\hline Middelbare wiskundige, natuurwetenschappelijke beroepen & - & gemiddeld \\
\hline Middelbare technische beroepen & 53 & erg hoog \\
\hline Middelbare transportberoepen & 37 & hoog \\
\hline Middelbare (para)medische beroepen & 11 & gemiddeld \\
\hline Middelbare administratieve, commerciële beroepen & 8 & laag \\
\hline Middelbare juridische, bestuurlijke beveiligingsberoepen & 15 & gemiddeld \\
\hline Middelbare taalkundige, culturele beroepen & - & laag \\
\hline Middelbare beroepen mbt gedrag en maatschappij & 16 & gemiddeld \\
\hline Middelbare verzorgende beroepen & 23 & gemiddeld \\
\hline Hogere pedagogische beroepen & 31 & hoog \\
\hline Hogere landbouwkundige beroepen & - & laag \\
\hline Hogere wiskundige, natuurwetenschappelijke beroepen & - & gemiddeld \\
\hline Hogere technische beroepen & 21 & gemiddeld \\
\hline Hogere transportberoepen & - & hoog \\
\hline Hogere (para)medische beroepen & 10 & laag \\
\hline Hogere administratieve, commerciële, economische beroepen & 6 & laag \\
\hline Hogere juridische, bestuurlijke, beveiligingsberoepen & - & gemiddeld \\
\hline Hogere taalkundige, culturele beroepen & - & laag \\
\hline Hogere beroepen mbt gedrag en maatschappij & 9 & laag \\
\hline Hogere verzorgende beroepen & - & laag \\
\hline Managers (HBO werk- en denkniveau) & - & gemiddeld \\
\hline Wetenschappelijke pedagogische beroepen & 17 & gemiddeld \\
\hline Wetenschappelijke landbouwkundige beroepen & - & gemiddeld \\
\hline Wetenschappelijke wiskundige, natuurwetenschappelijke beroepen & - & gemiddeld \\
\hline Wetenschappelijke technische beroepen & 13 & gemiddeld \\
\hline Wetenschappelijke (para)medische beroepen & - & laag \\
\hline Wetenschappelijke economische, administratieve beroepen & - & erg laag \\
\hline Wetenschappelijke juridische, bestuurlijke beroepen & - & erg laag \\
\hline Wetenschappelijke beroepen mbt gedrag en maatschappij & - & erg laag \\
\hline Managers (wetenschappelijk werk-en denkniveau) & - & laag \\
\hline
\end{tabular}

Bron: CBS/ROA 
Tabel 3.3

Percentage werknemers dat gebruik maakt van gereedschap of apparaten die trilling veroorzaken, naar beroepsgroep, 1996

Beroepsgroep $\quad \% \quad$ typering

\section{PEDAGOGISCHE BEROEPEN}

typering

Leraar basisonderwijs

Docenten exacte, medische en verzorgende vakken ( $2 \mathrm{e}$ graads)

Docenten exacte, medische en verzorgende vakken (1e graads)

Docenten landbouw en techniek (2e graads)

Docenten landbouw en techniek (1e graads)

Docenten economisch-administratieve vakken (2e graads)

Docenten economisch-administratieve vakken (1e graads)

Docenten talen en expressie

Docenten letteren (1e graads)

Docenten sociale vakken (2e graads)

Docenten sociale vakken (1e graads)

Docenten 2 e graads zonder specialisatie

Docent 1 e graads zonder specialisatie

Onderwijskundig medewerkers

Onderwijskundigen en pedagogen

Rij-instructeurs

Zweminstructeurs

Sportinstructeurs

\section{CULTURELE BEROEPEN}

Tolken, vertalers en schrijvers

Bibliotheekassistenten

Bibliothecarissen

Grafisch ontwerpers

Kunstenaars

Geestelijk verzorgers

Geestelijken

Journalisten

Taalkundigen

erg laag

gemiddeld

laag

hoog

laag

erg laag

erg laag

gemiddeld

laag

erg laag

erg laag

gemiddeld

gemiddeld

erg laag

laag

gemiddeld

gemiddeld

gemiddeld

\section{AGRARISCHE BEROEPEN}

Agrarische hulparbeiders

Agrarische arbeiders

Agrarische vakkrachten

Milieuhygiënisten en agrarisch vertegenwoordigers

Landbouwkundigen

Landbouwmachinebestuurders en vissers

Agrarische bedrijfshoofden

erg laag

erg laag

erg laag

laag

gemiddeld

erg laag

erg laag

erg laag

gemiddeld

\section{TECHNISCHE EN INDUSTRIEBEROEPEN}

Productiemedewerkers

Laboratorium-assistenten

Laboranten

Technisch analisten

Natuurwetenschappers

Conciërges

Hoofden technische dienst

Werktuigbouwkundigen

Bouwvakkers

Aannemers en installateurs

Architecten en bouwkundig projectleiders

Weg-en waterbouwkundigen

Weg-en waterbouwkundige arbeiders

Weg- en waterbouwkundige vakkrachten

Weg-en waterbouwkundig ontwerpers en projectleiders

Metaalarbeiders

Bankwerkers en lassers

Bedrijfshoofden metaalbewerking

Assembleurs

Monteurs

gemiddeld

hoog

hoog

gemiddeld

laag

erg hoog

hoog

$\begin{aligned} 31 & \text { hoog } \\ - & \text { hoog } \\ - & \text { hoog } \\ - & \text { gemiddeld } \\ - & \text { gemiddeld } \\ 21 & \text { hoog } \\ - & \text { hoog } \\ - & \text { gemiddeld } \\ 60 & \text { erg hoog } \\ 56 & \text { erg hoog } \\ - & \text { gemiddeld } \\ - & \text { erg laag } \\ 80 & \text { erg hoog } \\ 40 & \text { hoog } \\ - & \text { gemiddeld } \\ 58 & \text { erg hoog } \\ 54 & \text { erg hoog } \\ - & \text { hoog } \\ 50 & \text { erg hoog } \\ 56 & \text { erg hoog }\end{aligned}$


Tabel 3.3 (vervolg)

Percentage werknemers dat gebruik maakt van gereedschap of apparaten die trilling veroorzaken, naar beroepsgroep, 1996

\begin{tabular}{|c|c|c|}
\hline Beroepsgroep & $\%$ & typering \\
\hline $\begin{array}{l}\text { Werktuigbouwkundig ontwerpers en hoofden technische dienst } \\
\text { Elektronicamonteurs } \\
\text { Monteurs en controleurs elektrotechnische producten } \\
\text { Elektromonteurs } \\
\text { Elektrotechnisch ontwerpers en bedrijfshoofden } \\
\text { Elektrotechnici } \\
\text { Grafisch productiepersoneel } \\
\text { Grafische vakkrachten } \\
\text { Mechanisch operators } \\
\text { Procesoperators } \\
\text { Procestechnologen } \\
\text { Materiaalkundigen } \\
\text { Confectie-arbeiders } \\
\text { Schoen- en kleermakers }\end{array}$ & $\begin{array}{r}- \\
44 \\
43 \\
- \\
- \\
- \\
17 \\
27 \\
28 \\
- \\
- \\
- \\
-\end{array}$ & $\begin{array}{l}\text { gemiddeld } \\
\text { hoog } \\
\text { erg hoog } \\
\text { hoog } \\
\text { gemiddeld } \\
\text { gemiddeld } \\
\text { hoog } \\
\text { hoog } \\
\text { hoog } \\
\text { hoog } \\
\text { gemiddeld } \\
\text { gemiddeld } \\
\text { hoog } \\
\text { hoog }\end{array}$ \\
\hline \multicolumn{3}{|l|}{ TRANSPORTBEROEPEN } \\
\hline $\begin{array}{l}\text { Laders en lossers } \\
\text { Chauffeurs } \\
\text { Schippers en conducteurs } \\
\text { Vliegers, scheepskapiteins en leidinggevenden transport } \\
\text { Stewards }\end{array}$ & $\begin{array}{r}16 \\
12 \\
- \\
-\end{array}$ & $\begin{array}{l}\text { hoog } \\
\text { gemiddeld } \\
\text { hoog } \\
\text { gemiddeld } \\
\text { laag }\end{array}$ \\
\hline
\end{tabular}

\section{MEDISCHE EN PARAMEDISCHE BEROEPEN}

Verpleeghulpen en leerling-verpleegkundigen

Verplegenden en doktersassistenten

Therapeuten en verpleegkundigen

Artsen

Apothekersassistenten en medisch laboranten

Medisch analisten

Apothekers

Afdelingshoofden zorginstelling

laag

gemiddeld

gemiddeld

gemiddeld

gemiddeld

gemiddeld

gemiddeld

erg laag

\section{ECONOMISCH-ADMINISTRATIEVE BEROEPEN}

Kantoorhulpen, inpakkers en colporteurs

Ondersteunende administratieve hulpkrachten

Bedrijfshoofden

Economen

Productieplanners

Organisatie-adviseurs

Organisatiedeskundigen

Receptionisten en administratieve employés

Boekhouders en secretaresses

Assistent accountants

Accountants

Verzekeringsagenten

Commercieel employés

Commercieel medewerkers

Technisch-commercieel employés

Technisch-bedrijfskundig medewerkers

Juridisch en fiscaal medewerkers

Juridisch, bestuurlijk medewerkers

Juristen

Administratieve transportemployés

Leidinggevenden

Managers

Medisch secretaresses

gemiddeld

gemiddeld

laag

erg laag

gemiddeld

laag

erg laag

laag

laag

erg laag

erg laag

laag

laag

laag

gemiddeld

laag

erg laag

erg laag

erg laag

laag

laag

laag

INFORMATICABEROEPEN

Programmeurs

Systeemanalisten

Informatici

laag

erg laag

erg laag 
Tabel 3.3 (vervolg)

Percentage werknemers dat gebruik maakt van gereedschap of apparaten die trilling veroorzaken, naar beroepsgroep, 1996

\begin{tabular}{llc}
\hline Beroepsgroep & $\%$ & typering \\
\hline Technisch systeemanalisten & - & gemiddeld
\end{tabular}

SOCIAAL-CULTURELE BEROEPEN

Activiteitenbegeleiders en medewerkers arbeidsbemiddeling

Sociaal-cultureel werkers

Sociale raadslieden en hoofden personeelszaken

Sociaal-wetenschappelijk medewerkers

Sociaal-wetenschappelijk onderzoekers

gemiddeld

erg laag

erg laag

erg laag

erg laag

VERZORGENDE EN DIENSTVERLENENDE BEROEPEN

Vakkenvullers

Interieurverzorgers

Verkopers

Winkeliers

Hulpkrachten horeca en verzorging

Ziekenverzorgenden

Verzorgend personee

Café- en snackbarhouders

Bedrijfshoofden horeca

Bakkers en slagers

erg laag

2 gemiddeld

gemiddeld

gemiddeld

gemiddeld

laag

gemiddeld

erg laag

gemiddeld

hoog

OPENBARE ORDE- EN VEILIGHEIDSBEROEPEN

Adspirant politieagenten, soldaten en beveiligingshulpkrachten

Politieagenten, onderofficieren en beveiligingsemployés

Politie-inspecteurs en officieren

Brandweerlieden

13 gemiddeld

gemiddeld

gemiddeld

erg hoog

Bron: CBS/ROA 
Tabel 3.4

Percentage werknemers dat gebruik maakt van gereedschap of apparaten die trilling veroorzaken, naar beroepssegment, 1996

\begin{tabular}{|c|c|c|}
\hline Beroepssegment & $\%$ & typering \\
\hline Elementaire beroepen & 17 & hoog \\
\hline Lagere niet-specialistische beroepen & - & gemiddeld \\
\hline Lagere docenten sportvakken & - & gemiddeld \\
\hline Lagere agrarische beroepen & 41 & hoog \\
\hline Lagere wiskundige, natuurwetenschappelijke beroepen & - & hoog \\
\hline Lagere technische beroepen & 48 & erg hoog \\
\hline Lagere transportberoepen & 12 & gemiddeld \\
\hline Lagere (para)medische beroepen & - & laag \\
\hline Lagere administratieve, commerciële beroepen & 3 & laag \\
\hline Lagere beveiligingsberoepen & 13 & gemiddeld \\
\hline Lagere verzorgende beroepen & 5 & gemiddeld \\
\hline Middelbare docenten transport-, sportvakken & - & gemiddeld \\
\hline Middelbare agrarische beroepen & - & hoog \\
\hline Middelbare wiskundige, natuurwetenschappelijke beroepen & - & hoog \\
\hline Middelbare technische beroepen & 47 & erg hoog \\
\hline Middelbare transportberoepen & - & gemiddeld \\
\hline Middelbare (para)medische beroepen & 6 & gemiddeld \\
\hline Middelbare administratieve, commerciële beroepen & 2 & laag \\
\hline Middelbare juridische, bestuurlijke beveiligingsberoepen & - & gemiddeld \\
\hline Middelbare taalkundige, culturele beroepen & - & erg laag \\
\hline Middelbare beroepen mbt gedrag en maatschappij & - & gemiddeld \\
\hline Middelbare verzorgende beroepen & 4 & gemiddeld \\
\hline Hogere pedagogische beroepen & 4 & gemiddeld \\
\hline Hogere landbouwkundige beroepen & - & gemiddeld \\
\hline Hogere wiskundige, natuurwetenschappelijke beroepen & - & gemiddeld \\
\hline Hogere technische beroepen & 10 & gemiddeld \\
\hline Hogere transportberoepen & - & gemiddeld \\
\hline Hogere (para)medische beroepen & 6 & gemiddeld \\
\hline Hogere administratieve, commerciële, economische beroepen & - & erg laag \\
\hline Hogere juridische, bestuurlijke, beveiligingsberoepen & - & laag \\
\hline Hogere taalkundige, culturele beroepen & - & gemiddeld \\
\hline Hogere beroepen mbt gedrag en maatschappij & - & erg laag \\
\hline Hogere verzorgende beroepen & - & erg laag \\
\hline Managers (HBO werk- en denkniveau) & - & laag \\
\hline Wetenschappelijke pedagogische beroepen & - & laag \\
\hline Wetenschappelijke landbouwkundige beroepen & - & laag \\
\hline Wetenschappelijke wiskundige, natuurwetenschappelijke beroepen & - & gemiddeld \\
\hline Wetenschappelijke technische beroepen & - & gemiddeld \\
\hline Wetenschappelijke (para)medische beroepen & - & gemiddeld \\
\hline Wetenschappelijke economische,administratieve beroepen & - & erg laag \\
\hline Wetenschappelijke juridische, bestuurlijke beroepen & - & erg laag \\
\hline Wetenschappelijke beroepen mbt gedrag en maatschappij & - & erg laag \\
\hline Managers (wetenschappelijk werk-en denkniveau) & - & laag \\
\hline
\end{tabular}

Bron: CBS/ROA 
Tabel 3.5

Percentage werknemers dat kracht moet zetten tijdens het werk, naar beroepsgroep, 1996

\begin{tabular}{lll}
\hline Beroepsgroep & $\%$ & typering
\end{tabular}

\section{PEDAGOGISCHE BEROEPEN}

Leraar basisonderwijs

Docenten exacte, medische en verzorgende vakken ( $2 \mathrm{e}$ graads)

Docenten exacte, medische en verzorgende vakken (1e graads)

Docenten landbouw en techniek (2e graads)

Docenten landbouw en techniek (1e graads)

Docenten economisch-administratieve vakken (2e graads)

Docenten economisch-administratieve vakken (1e graads)

Docenten talen en expressie

Docenten letteren (1e graads)

Docenten sociale vakken (2e graads)

Docenten sociale vakken (1e graads)

Docenten 2 e graads zonder specialisatie

Docent 1 e graads zonder specialisatie

Onderwijskundig medewerkers

Onderwijskundigen en pedagogen

Rij-instructeurs

Zweminstructeurs

Sportinstructeurs

\section{CULTURELE BEROEPEN}

Tolken, vertalers en schrijvers

Bibliotheekassistenten

Bibliothecarissen

Grafisch ontwerpers

Kunstenaars

Geestelijk verzorgers

Geestelijken

Journalisten

Taalkundigen

\section{AGRARISCHE BEROEPEN}

Agrarische hulparbeiders

Agrarische arbeiders

Agrarische vakkrachten

Milieuhygiënisten en agrarisch vertegenwoordigers

Landbouwkundigen

Landbouwmachinebestuurders en vissers

Agrarische bedrijfshoofden

\section{TECHNISCHE EN INDUSTRIEBEROEPEN}

Productiemedewerkers

Laboratorium-assistenten

Laboranten

Technisch analisten

Natuurwetenschappers

Conciërges

Hoofden technische dienst

Werktuigbouwkundigen

Bouwvakkers

Aannemers en installateurs

Architecten en bouwkundig projectleiders

Weg-en waterbouwkundigen

Weg- en waterbouwkundige arbeiders

Weg- en waterbouwkundige vakkrachten

Weg-en waterbouwkundig ontwerpers en projectleiders

Metaalarbeiders

Bankwerkers en lassers

Bedrijfshoofden metaalbewerking

Assembleurs

Monteurs

Werktuigbouwkundig ontwerpers en hoofden technische dienst gemiddeld

laag

laag

gemiddeld

laag

erg laag

erg laag

gemiddeld

erg laag

gemiddeld

laag

gemiddeld

gemiddeld

erg laag

laag

laag

gemiddeld

hoog

erg laag

gemiddeld

gemiddeld

laag

gemiddeld

erg laag

erg laag

laag

gemiddeld

hoog

erg hoog

hoog

gemiddeld

gemiddeld

hoog

hoog

hoog

gemiddeld gemiddeld gemiddeld

laag

hoog

gemiddeld

gemiddeld

erg hoog

erg hoog

gemiddeld

laag

erg hoog

gemiddeld

gemiddeld

erg hoog

hoog

gemiddeld

hoog

hoog

gemiddeld 
Tabel 3.5 (vervolg)

Percentage werknemers dat kracht moet zetten tijdens het werk, naar beroepsgroep, 1996

\begin{tabular}{lrl}
\hline Beroepsgroep & $\%$ & typering \\
\hline Elektronicamonteurs & - & gemiddeld \\
Monteurs en controleurs elektrotechnische producten & 48 & hoog \\
Elektromonteurs & 55 & hoog \\
Elektrotechnisch ontwerpers en bedrijfshoofden & - & gemiddeld \\
Elektrotechnici & $-\bar{l}$ erg laag \\
Grafisch productiepersoneel & 30 & gemiddeld \\
Grafische vakkrachten & 39 & gemiddeld \\
Mechanisch operators & 64 & hoog \\
Procesoperators & 49 & hoog \\
Procestechnologen & - & gemiddeld \\
Materiaalkundigen & $-\overline{g e m i d d e l d ~}$ \\
Confectie-arbeiders & 57 & hoog \\
Schoen- en kleermakers & - & gemiddeld
\end{tabular}

\section{TRANSPORTBEROEPEN}

Laders en lossers

Chauffeurs

Schippers en conducteurs

Vliegers, scheepskapiteins en leidinggevenden transport

Stewards

$\begin{array}{ll}76 & \text { erg hoog } \\ 59 & \text { hoog } \\ 37 & \text { gemiddeld } \\ 69 & \text { gemiddeld } \\ 69 & \text { erg hoog }\end{array}$

\section{MEDISCHE EN PARAMEDISCHE BEROEPEN}

Verpleeghulpen en leerling-verpleegkundigen

Verplegenden en doktersassistenten

Therapeuten en verpleegkundigen

Artsen

Apothekersassistenten en medisch laboranten

Medisch analisten

Apothekers

Afdelingshoofden zorginstelling

erg hoog
hoog
hoog
gemiddeld
gemiddeld
gemiddeld
erg laag
gemiddeld

\section{ECONOMISCH-ADMINISTRATIEVE BEROEPEN}

Kantoorhulpen, inpakkers en colporteurs

Ondersteunende administratieve hulpkrachten

Bedrijfshoofden

Economen

Productieplanners

Organisatie-adviseurs

Organisatiedeskundigen

Receptionisten en administratieve employés

Boekhouders en secretaresses

Assistent accountants

Accountants

Verzekeringsagenten

Commercieel employés

Commercieel medewerkers

Technisch-commercieel employés

Technisch-bedrijfskundig medewerkers

Juridisch en fiscaal medewerkers

Juridisch, bestuurlijk medewerkers

Juristen

Administratieve transportemployés

Leidinggevenden

Managers

Medisch secretaresses

$\begin{aligned} 51 & \text { hoog } \\ - & \text { gemiddeld } \\ - & \text { gemidddeld } \\ - & \text { erg laag } \\ 13 & \text { gemidddeld } \\ - & \text { laag } \\ - & \text { erg laag } \\ 11 & \text { gemiddeld } \\ 6 & \text { laag } \\ - & \text { erg laag } \\ - & \text { erg laag } \\ - & \text { laag } \\ 9 & \text { gemiddeld } \\ 5 & \text { laag } \\ - & \text { gemiddeld } \\ - & \text { laag } \\ - & \text { laag } \\ - & \text { laag } \\ - & \text { erg laag } \\ - & \text { gemiddeld } \\ - & \text { laag } \\ - & \text { laag } \\ - & \text { laag }\end{aligned}$

\section{INFORMATICABEROEPEN}

Programmeurs

Systeemanalisten

Informatici

Technisch systeemanalisten 
Tabel 3.5 (vervolg)

Percentage werknemers dat kracht moet zetten tijdens het werk, naar beroepsgroep, 1996

SOCIAAL-CULTURELE BEROEPEN

Activiteitenbegeleiders en medewerkers arbeidsbemiddeling Sociaal-cultureel werkers

Sociale raadslieden en hoofden personeelszaken

Sociaal-wetenschappelijk medewerkers

Sociaal-wetenschappelijk onderzoekers

$\begin{aligned} 27 & \text { gemiddeld } \\ 8 & \text { gemiddeld } \\ - & \text { laag } \\ - & \text { laag } \\ - & \text { erg laag }\end{aligned}$

\title{
VERZORGENDE EN DIENSTVERLENENDE BEROEPEN
}

\author{
Vakkenvullers \\ Interieurverzorgers \\ Verkopers \\ Winkeliers \\ Hulpkrachten horeca en verzorging \\ Ziekenverzorgenden \\ Verzorgend personeel \\ Café- en snackbarhouders \\ Bedriifshoofden horeca \\ Bakkers en slagers
}

$\begin{aligned} 65 & \text { hoog } \\ 59 & \text { hoog } \\ 45 & \text { gemiddeld } \\ 49 & \text { hoog } \\ 59 & \text { hoog } \\ 87 & \text { erg hoog } \\ 62 & \text { hoog } \\ - & \text { hoog } \\ 40 & \text { gemiddeld } \\ - & \text { erg hoog }\end{aligned}$

\section{OPENBARE ORDE- EN VEILIGHEIDSBEROEPEN}

Adspirant politieagenten, soldaten en beveiligingshulpkrachten

Politieagenten, onderofficieren en beveiligingsemployés

Politie-inspecteurs en officieren

Brandweerlieden

Bron: CBS/ROA 
Tabel 3.6

Percentage werknemers dat kracht moet zetten tijdens het werk, naar beroepssegment, 1996

\begin{tabular}{|c|c|c|}
\hline Beroepssegment & $\%$ & typering \\
\hline Elementaire beroepen & 63 & hoog \\
\hline Lagere niet-specialistische beroepen & - & gemiddeld \\
\hline Lagere docenten sportvakken & - & gemiddeld \\
\hline Lagere agrarische beroepen & 72 & erg hoog \\
\hline Lagere wiskundige, natuurwetenschappelijke beroepen & - & gemiddeld \\
\hline Lagere technische beroepen & 70 & erg hoog \\
\hline Lagere transportberoepen & 59 & hoog \\
\hline Lagere (para)medische beroepen & 90 & erg hoog \\
\hline Lagere administratieve, commerciële beroepen & 27 & gemiddeld \\
\hline Lagere beveiligingsberoepen & 25 & gemiddeld \\
\hline Lagere verzorgende beroepen & 59 & hoog \\
\hline Middelbare docenten transport-, sportvakken & - & gemiddeld \\
\hline Middelbare agrarische beroepen & 64 & hoog \\
\hline Middelbare wiskundige, natuurwetenschappelijke beroepen & - & gemiddeld \\
\hline Middelbare technische beroepen & 59 & hoog \\
\hline Middelbare transportberoepen & 32 & gemiddeld \\
\hline Middelbare (para)medische beroepen & 56 & hoog \\
\hline Middelbare administratieve, commerciële beroepen & 11 & gemiddeld \\
\hline Middelbare juridische, bestuurlijke beveiligingsberoepen & 18 & gemiddeld \\
\hline Middelbare taalkundige, culturele beroepen & - & gemiddeld \\
\hline Middelbare beroepen mbt gedrag en maatschappij & 27 & gemiddeld \\
\hline Middelbare verzorgende beroepen & 60 & hoog \\
\hline Hogere pedagogische beroepen & 12 & gemiddeld \\
\hline Hogere landbouwkundige beroepen & - & gemiddeld \\
\hline Hogere wiskundige, natuurwetenschappelijke beroepen & - & gemiddeld \\
\hline Hogere technische beroepen & 11 & gemiddeld \\
\hline Hogere transportberoepen & - & gemiddeld \\
\hline Hogere (para)medische beroepen & 55 & hoog \\
\hline Hogere administratieve, commerciële, economische beroepen & 4 & laag \\
\hline Hogere juridische, bestuurlijke, beveiligingsberoepen & - & laag \\
\hline Hogere taalkundige, culturele beroepen & 18 & gemiddeld \\
\hline Hogere beroepen mbt gedrag en maatschappij & 7 & laag \\
\hline Hogere verzorgende beroepen & - & gemiddeld \\
\hline Managers (HBO werk- en denkniveau) & - & laag \\
\hline Wetenschappelijke pedagogische beroepen & - & laag \\
\hline Wetenschappelijke landbouwkundige beroepen & - & gemiddeld \\
\hline Wetenschappelijke wiskundige, natuurwetenschappelijke beroepen & - & laag \\
\hline Wetenschappelijke technische beroepen & - & laag \\
\hline Wetenschappelijke (para)medische beroepen & - & gemiddeld \\
\hline Wetenschappelijke economische,administratieve beroepen & - & erg laag \\
\hline Wetenschappelijke juridische, bestuurlijke beroepen & - & erg laag \\
\hline Wetenschappelijke beroepen mbt gedrag en maatschappij & - & laag \\
\hline Managers (wetenschappelijk werk-en denkniveau) & - & laag \\
\hline
\end{tabular}

Bron: CBS/ROA 
Tabel 3.7

Percentage werknemers dat werkzaam is in ploegendienst, naar beroepsgroep, 1996

\begin{tabular}{lll}
\hline Beroepsgroep & $\%$ & typering
\end{tabular}

\section{PEDAGOGISCHE BEROEPEN}

Leraar basisonderwijs

Docenten exacte, medische en verzorgende vakken ( $2 \mathrm{e}$ graads)

Docenten exacte, medische en verzorgende vakken (1e graads)

Docenten landbouw en techniek (2e graads)

Docenten landbouw en techniek ( $1 \mathrm{e}$ graads)

Docenten economisch-administratieve vakken ( $2 \mathrm{e}$ graads)

Docenten economisch-administratieve vakken (1e graads)

Docenten talen en expressie

Docenten letteren (1e graads)

Docenten sociale vakken ( 2 e graads)

Docenten sociale vakken (1e graads)

Docenten 2 e graads zonder specialisatie

Docent $1 \mathrm{e}$ graads zonder specialisatie

Onderwijskundig medewerkers

Onderwijskundigen en pedagogen

Rij-instructeurs

Zweminstructeurs

Sportinstructeurs

\section{CULTURELE BEROEPEN}

Tolken, vertalers en schrijvers

Bibliotheekassistenten

Bibliothecarissen

Grafisch ontwerpers

Kunstenaars

Geestelijk verzorgers

Geestelijken

Journalisten

Taalkundigen
erg laag
erg laag
erg laag
gemiddeld
erg laag
erg laag
erg laag
erg laag
erg laag
erg laag
erg laag
erg laag
erg laag
erg laag
erg laag
laag
erg hoog
gemiddeld

gemiddeld

laag

erg laag

erg laag

laag

erg laag

erg laag

gemiddeld

laag

\section{AGRARISCHE BEROEPEN}

Agrarische hulparbeiders

Agrarische arbeiders

Agrarische vakkrachten

Milieuhygiënisten en agrarisch vertegenwoordigers

Landbouwkundigen

Landbouwmachinebestuurders en vissers

Agrarische bedrijfshoofden

\section{TECHNISCHE EN INDUSTRIEBEROEPEN}

Productiemedewerkers

Laboratorium-assistenten

Laboranten

Technisch analisten

Natuurwetenschappers

Conciërges

Hoofden technische dienst

Werktuigbouwkundigen

Bouwvakkers

Aannemers en installateurs

Architecten en bouwkundig projectleiders

Weg-en waterbouwkundigen

Weg-en waterbouwkundige arbeiders

Weg-en waterbouwkundige vakkrachten

Weg- en waterbouwkundig ontwerpers en projectleiders

Metaalarbeiders

Bankwerkers en lassers

Bedrijfshoofden metaalbewerking

Assembleurs

Monteurs

Werktuigbouwkundig ontwerpers en hoofden technische dienst erg laag

laag

gemiddeld

erg laag

erg laag

gemiddeld

erg laag

hoog
hoog
gemiddeld
gemiddeld
laag
gemiddeld
erg laag
laag
laag
laag
laag
erg laag
gemiddeld
laag
laag
hoog
hoog
gemiddeld
hoog
gemiddeld
gemiddeld


Tabel 3.7 (vervolg)

Percentage werknemers dat werkzaam is in ploegendienst, naar beroepsgroep, 1996

\begin{tabular}{lcl}
\hline Beroepsgroep & $\%$ & typering \\
\hline Elektronicamonteurs & - & gemiddeld \\
Monteurs en controleurs elektrotechnische producten & - & hoog \\
Elektromonteurs & 8 & gemiddeld \\
Elektrotechnisch ontwerpers en bedrijfshoofden & - & erg laag \\
Elektrotechnici & - & erg laag \\
Grafisch productiepersoneel & 38 & erg hoog \\
Grafische vakkrachten & 26 & hoog \\
Mechanisch operators & 46 & erg hoog \\
Procesoperators & 68 & erg hoog \\
Procestechnologen & - & laag \\
Materiaalkundigen & - & laag \\
Confectie-arbeiders & - & gemiddeld \\
Schoen- en kleermakers & - & gemiddeld
\end{tabular}

Schoen- en kleermakers

gemiddeld

TRANSPORTBEROEPEN

Laders en lossers

Chauffeurs

Schippers en conducteurs

Vliegers, scheepskapiteins en leidinggevenden transport

Stewards

gemiddeld

hoog

erg hoog

hoog

MEDISCHE EN PARAMEDISCHE BEROEPEN

Verpleeghulpen en leerling-verpleegkundigen

Verplegenden en doktersassistenten

Therapeuten en verpleegkundigen

Artsen

Apothekersassistenten en medisch laboranten

Medisch analisten

Apothekers

Afdelingshoofden zorginstelling

\section{ECONOMISCH-ADMINISTRATIEVE BEROEPEN}

Kantoorhulpen, inpakkers en colporteurs

Ondersteunende administratieve hulpkrachten

Bedrijfshoofden

Economen

Productieplanners

Organisatie-adviseurs

Organisatiedeskundigen

Receptionisten en administratieve employés

Boekhouders en secretaresses

Assistent accountants

Accountants

Verzekeringsagenten

Commercieel employés

Commercieel medewerkers

Technisch-commercieel employés

Technisch-bedrijfskundig medewerkers

Juridisch en fiscaal medewerkers

Juridisch, bestuurlijk medewerkers

Juristen

Administratieve transportemployés

Leidinggevenden

Managers

Medisch secretaresses

erg hoog

hoog

hoog

gemiddeld

gemiddeld

hoog

gemiddeld

gemiddeld

\section{INFORMATICABEROEPEN}

Programmeurs

Systeemanalisten

Informatici

Technisch systeemanalisten

gemiddeld

erg laag

erg laag

laag 
Tabel 3.7 (vervolg)

Percentage werknemers dat werkzaam is in ploegendienst, naar beroepsgroep, 1996

Beroepsgroep $\quad \% \quad$ typering

SOCIAAL-CULTURELE BEROEPEN

Activiteitenbegeleiders en medewerkers arbeidsbemiddeling

Sociaal-cultureel werkers

Sociale raadslieden en hoofden personeelszaken

Sociaal-wetenschappelijk medewerkers

typering

Sociaal-wetenschappelijk onderzoekers

12 gemiddeld

- $\quad$ gemiddeld

- laag

- $\quad$ erg laag

VERZORGENDE EN DIENSTVERLENENDE BEROEPEN

Vakkenvullers

Interieurverzorgers

Verkopers

Winkeliers

Hulpkrachten horeca en verzorging

Ziekenverzorgenden

Verzorgend personeel

Café- en snackbarhouders

Bedrijfshoofden horeca

Bakkers en slagers

hoog

gemiddeld

gemiddeld

laag

gemiddeld

erg hoog

hoog

hoog

hoog

hoog

OPENBARE ORDE- EN VEILIGHEIDSBEROEPEN

Adspirant politieagenten, soldaten en beveiligingshulpkrachten

Politieagenten, onderofficieren en beveiligingsemployés

48 erg hoog

Politie-inspecteurs en officieren

erg hoog

Brandweerlieden

Bron: CBS/ROA 
Tabel 3.8

Percentage werknemers dat werkzaam is in ploegendienst, naar beroepssegment, 1996

\begin{tabular}{|c|c|c|}
\hline Beroepssegment & $\%$ & typering \\
\hline Elementaire beroepen & 16 & gemiddeld \\
\hline Lagere niet-specialistische beroepen & - & erg laag \\
\hline Lagere docenten sportvakken & - & erg hoog \\
\hline Lagere agrarische beroepen & - & laag \\
\hline Lagere wiskundige, natuurwetenschappelijke beroepen & - & hoog \\
\hline Lagere technische beroepen & 17 & hoog \\
\hline Lagere transportberoepen & 19 & hoog \\
\hline Lagere (para)medische beroepen & 59 & erg hoog \\
\hline Lagere administratieve, commerciële beroepen & 6 & gemiddeld \\
\hline Lagere beveiligingsberoepen & 48 & erg hoog \\
\hline Lagere verzorgende beroepen & 15 & gemiddeld \\
\hline Middelbare docenten transport-, sportvakken & - & laag \\
\hline Middelbare agrarische beroepen & - & laag \\
\hline Middelbare wiskundige, natuurwetenschappelijke beroepen & - & gemiddeld \\
\hline Middelbare technische beroepen & 16 & gemiddeld \\
\hline Middelbare transportberoepen & 28 & hoog \\
\hline Middelbare (para)medische beroepen & 32 & hoog \\
\hline Middelbare administratieve, commerciële beroepen & 3 & laag \\
\hline Middelbare juridische, bestuurlijke beveiligingsberoepen & 27 & hoog \\
\hline Middelbare taalkundige, culturele beroepen & - & laag \\
\hline Middelbare beroepen mbt gedrag en maatschappij & 12 & gemiddeld \\
\hline Middelbare verzorgende beroepen & 22 & hoog \\
\hline Hogere pedagogische beroepen & - & erg laag \\
\hline Hogere landbouwkundige beroepen & - & erg laag \\
\hline Hogere wiskundige, natuurwetenschappelijke beroepen & - & gemiddeld \\
\hline Hogere technische beroepen & - & laag \\
\hline Hogere transportberoepen & - & hoog \\
\hline Hogere (para)medische beroepen & 21 & hoog \\
\hline Hogere administratieve, commerciële, economische beroepen & - & erg laag \\
\hline Hogere juridische, bestuurlijke, beveiligingsberoepen & - & laag \\
\hline Hogere taalkundige, culturele beroepen & - & laag \\
\hline Hogere beroepen mbt gedrag en maatschappij & 6 & gemiddeld \\
\hline Hogere verzorgende beroepen & - & gemiddeld \\
\hline Managers (HBO werk- en denkniveau) & - & gemiddeld \\
\hline Wetenschappelijke pedagogische beroepen & - & erg laag \\
\hline Wetenschappelijke landbouwkundige beroepen & - & erg laag \\
\hline Wetenschappelijke wiskundige, natuurwetenschappelijke beroepen & - & laag \\
\hline Wetenschappelijke technische beroepen & - & laag \\
\hline Wetenschappelijke (para)medische beroepen & - & gemiddeld \\
\hline Wetenschappelijke economische,administratieve beroepen & - & erg laag \\
\hline Wetenschappelijke juridische, bestuurlijke beroepen & - & erg laag \\
\hline Wetenschappelijke beroepen mbt gedrag en maatschappij & - & erg laag \\
\hline Managers (wetenschappelijk werk-en denkniveau) & - & gemiddeld \\
\hline
\end{tabular}

Bron: CBS/ROA 
Tabel 3.9

Percentage werknemers dat onder hoge tijdsdruk werkt, naar beroepsgroep, 1996

\begin{tabular}{lll}
\hline Beroepsgroep & $\%$ typering
\end{tabular}

\section{PEDAGOGISCHE BEROEPEN}

Leraar basisonderwijs

Docenten exacte, medische en verzorgende vakken ( $2 \mathrm{e}$ graads)

Docenten exacte, medische en verzorgende vakken (1e graads)

Docenten landbouw en techniek (2e graads)

Docenten landbouw en techniek (1e graads)

Docenten economisch-administratieve vakken ( $2 \mathrm{e}$ graads)

Docenten economisch-administratieve vakken (1e graads)

Docenten talen en expressie

Docenten letteren (1e graads)

Docenten sociale vakken ( 2 e graads)

Docenten sociale vakken (1e graads)

Docenten 2 e graads zonder specialisatie

Docent 1 e graads zonder specialisatie

Onderwijskundig medewerkers

Onderwijskundigen en pedagogen

Rij-instructeurs

Zweminstructeurs

Sportinstructeurs

$\begin{aligned} 48 & \text { erg laag } \\ 56 & \text { laag } \\ 75 & \text { gemiddeld } \\ 57 & \text { laag } \\ - & \text { gemiddeld } \\ 66 & \text { gemiddeld } \\ - & \text { gemiddeld } \\ 56 & \text { laag } \\ 71 & \text { gemiddeld } \\ 43 & \text { erg laag } \\ - & \text { gemiddeld } \\ 57 & \text { laag } \\ - & \text { hoog } \\ 84 & \text { hoog } \\ 77 & \text { hoog } \\ - & \text { laag } \\ - & \text { erg laag } \\ - & \text { erg laag }\end{aligned}$

\section{CULTURELE BEROEPEN}

Tolken, vertalers en schrijvers

Bibliotheekassistenten

Bibliothecarissen

Grafisch ontwerpers

Kunstenaars

Geestelijk verzorgers

Geestelijken

Journalisten

Taalkundigen

erg laag

\section{AGRARISCHE BEROEPEN}

Agrarische hulparbeiders

Agrarische arbeiders

Agrarische vakkrachten

Milieuhygiënisten en agrarisch vertegenwoordigers

Landbouwkundigen

Landbouwmachinebestuurders en vissers

Agrarische bedrijfshoofden

\section{TECHNISCHE EN INDUSTRIEBEROEPEN}

Productiemedewerkers

Laboratorium-assistenten

Laboranten

Technisch analisten

Natuurwetenschappers

Conciërges

Hoofden technische dienst

Werktuigbouwkundigen

Bouwvakkers

Aannemers en installateurs

Architecten en bouwkundig projectleiders

Weg- en waterbouwkundigen

Weg-en waterbouwkundige arbeiders

Weg-en waterbouwkundige vakkrachten

Weg- en waterbouwkundig ontwerpers en projectleiders

Metaalarbeiders

Bankwerkers en lassers

Bedrijfshoofden metaalbewerking

Assembleurs

Monteurs

Werktuigbouwkundig ontwerpers en hoofden technische dienst

$\begin{aligned}- & \text { gemiddeld } \\ 52 & \text { laag } \\ 52 & \text { laag } \\ - & \text { hoog } \\ 79 & \text { hoog } \\ - & \text { erg hoog } \\ - & \text { gemiddeld } \\ 90 & \text { erg hoog } \\ 84 & \text { hoog }\end{aligned}$

$\begin{aligned} 37 & \text { erg laag } \\ - & \text { erg laag } \\ 65 & \text { laag } \\ - & \text { gemiddeld } \\ - & \text { hoog } \\ - & \text { gemiddeld } \\ - & \text { gemiddeld }\end{aligned}$

$\begin{aligned} 52 & \text { laag } \\ - & \text { gemiddeld } \\ 57 & \text { laag } \\ 55 & \text { laag } \\ 71 & \text { gemiddeld } \\ 41 & \text { erg laag } \\ 69 & \text { gemiddeld } \\ 85 & \text { hoog } \\ 49 & \text { laag } \\ 61 & \text { gemiddeld } \\ 84 & \text { hoog } \\ 88 & \text { erg hoog } \\ 44 & \text { erg laag } \\ 57 & \text { laag } \\ 79 & \text { hoog } \\ 52 & \text { laag } \\ 57 & \text { laag } \\ - & \text { gemiddeld } \\ 55 & \text { laag } \\ 61 & \text { gemiddeld } \\ 77 & \text { hoog }\end{aligned}$


Tabel 3.9 (vervolg)

Percentage werknemers dat onder hoge tijdsdruk werkt, naar beroepsgroep, 1996

\begin{tabular}{|c|c|c|}
\hline Beroepsgroep & $\%$ & typering \\
\hline $\begin{array}{l}\text { Elektronicamonteurs } \\
\text { Monteurs en controleurs elektrotechnische producten } \\
\text { Elektromonteurs } \\
\text { Elektrotechnisch ontwerpers en bedrijfshoofden } \\
\text { Elektrotechnici } \\
\text { Grafisch productiepersoneel } \\
\text { Grafische vakkrachten } \\
\text { Mechanisch operators } \\
\text { Procesoperators } \\
\text { Procestechnologen } \\
\text { Materiaalkundigen } \\
\text { Confectie-arbeiders } \\
\text { Schoen- en kleermakers }\end{array}$ & $\begin{array}{l}60 \\
55 \\
63 \\
71 \\
72 \\
72 \\
69 \\
55 \\
67 \\
61 \\
77 \\
56\end{array}$ & $\begin{array}{l}\text { gemiddeld } \\
\text { laag } \\
\text { gemiddeld } \\
\text { gemiddeld } \\
\text { gemiddeld } \\
\text { gemiddeld } \\
\text { gemiddeld } \\
\text { laag } \\
\text { gemiddeld } \\
\text { gemiddeld } \\
\text { hoog } \\
\text { laag } \\
\text { hoog }\end{array}$ \\
\hline
\end{tabular}

TRANSPORTBEROEPEN

Laders en lossers

Chauffeurs

Schippers en conducteurs

Vliegers, scheepskapiteins en leidinggevenden transport

Stewards

$\begin{array}{ll}51 & \text { laag } \\ 60 & \text { gemiddeld } \\ 67 & \text { gemiddeld } \\ 77 & \text { hoog } \\ 92 & \text { erg hoog }\end{array}$

\section{MEDISCHE EN PARAMEDISCHE BEROEPEN}

Verpleeghulpen en leerling-verpleegkundigen

Verplegenden en doktersassistenten

Therapeuten en verpleegkundigen

Artsen

Apothekersassistenten en medisch laboranten

Medisch analisten

Apothekers

Afdelingshoofden zorginstelling

$\begin{array}{ll}74 & \text { gemiddeld } \\ 72 & \text { gemiddeld } \\ 70 & \text { gemiddeld } \\ 83 & \text { hoog } \\ 59 & \text { gemiddeld } \\ 64 & \text { gemiddeld } \\ 6- & \text { erg hoog } \\ 66 & \text { gemiddeld }\end{array}$

\section{ECONOMISCH-ADMINISTRATIEVE BEROEPEN}

Kantoorhulpen, inpakkers en colporteurs

Ondersteunende administratieve hulpkrachten

Bedrijfshoofden

Economen

Productieplanners

Organisatie-adviseurs

Organisatiedeskundigen

Receptionisten en administratieve employés

Boekhouders en secretaresses

Assistent accountants

Accountants

Verzekeringsagenten

Commercieel employés

Commercieel medewerkers

Technisch-commercieel employés

Technisch-bedrijfskundig medewerkers

Juridisch en fiscaal medewerkers

Juridisch, bestuurlijk medewerkers

Juristen

Administratieve transportemployés

Leidinggevenden

Managers

Medisch secretaresses

$\begin{array}{cl}48 & \text { erg laag } \\ 9- & \text { laag } \\ 90 & \text { erg hoog } \\ 87 & \text { erg hoog } \\ 74 & \text { gemiddeld } \\ 78 & \text { hoog } \\ 86 & \text { erg hoog } \\ 53 & \text { laag } \\ 62 & \text { gemiddeld } \\ 75 & \text { gemiddeld } \\ 87 & \text { erg hoog } \\ 66 & \text { gemiddeld } \\ 64 & \text { gemiddeld } \\ 77 & \text { hoog } \\ 63 & \text { gemiddeld } \\ 75 & \text { gemiddeld } \\ 65 & \text { gemiddeld } \\ 85 & \text { erg hoog } \\ 82 & \text { hoog } \\ 77 & \text { hoog } \\ 86 & \text { erg hoog } \\ 85 & \text { erg hoog } \\ 61 & \text { gemiddeld }\end{array}$

\section{INFORMATICABEROEPEN}

Programmeurs

Systeemanalisten

Informatici

Technisch systeemanalisten

$\begin{array}{ll}68 & \text { gemiddeld } \\ 83 & \text { hoog } \\ 79 & \text { hoog } \\ 86 & \text { erg hoog }\end{array}$


Tabel 3.9 (vervolg)

Percentage werknemers dat onder hoge tijdsdruk werkt, naar beroepsgroep, 1996

$\begin{array}{lll}\text { Beroepsgroep } & \% \quad \text { typering }\end{array}$

SOCIAAL-CULTURELE BEROEPEN

Activiteitenbegeleiders en medewerkers arbeidsbemiddeling

Sociaal-cultureel werkers

Sociale raadslieden en hoofden personeelszaken

Sociaal-wetenschappelijk medewerkers

Sociaal-wetenschappelijk onderzoekers

71 gemiddeld

80 hoog

85 hoog

VERZORGENDE EN DIENSTVERLENENDE BEROEPEN

Vakkenvullers

Interieurverzorgers

Verkopers

Winkeliers

Hulpkrachten horeca en verzorging

Ziekenverzorgenden

Verzorgend personeel

Café- en snackbarhouders

Bedriifshoofden horeca

Bakkers en slagers

$\begin{array}{ll}45 & \text { erg laag } \\ 44 & \text { erg laag } \\ 40 & \text { erg laag } \\ 59 & \text { gemiddeld } \\ 55 & \text { laag } \\ 76 & \text { gemiddeld } \\ 58 & \text { laag } \\ - & \text { gemiddeld } \\ 60 & \text { gemiddeld } \\ - & \text { gemiddeld }\end{array}$

OPENBARE ORDE- EN VEILIGHEIDSBEROEPEN

Adspirant politieagenten, soldaten en beveiligingshulpkrachten

Politieagenten, onderofficieren en beveiligingsemployés

$44 \quad$ erg laag

Politie-inspecteurs en officieren

70 gemiddeld

Brandweerlieden

Bron: CBS/ROA 
Tabel 3.10

Percentage werknemers dat onder hoge tijdsdruk werkt, naar beroepssegment, 1996

\begin{tabular}{|c|c|c|}
\hline Beroepssegment & $\%$ & typering \\
\hline $\begin{array}{l}\text { Elementaire beroepen } \\
\text { Lagere niet-specialistische beroepen } \\
\text { Lagere docenten sportvakken } \\
\text { Lagere agrarische beroepen } \\
\text { Lagere wiskundige, natuurwetenschappelijke beroepen } \\
\text { Lagere technische beroepen } \\
\text { Lagere transportberoepen } \\
\text { Lagere (para)medische beroepen } \\
\text { Lagere administratieve, commerciële beroepen } \\
\text { Lagere beveiligingsberoepen } \\
\text { Lagere verzorgende beroepen } \\
\text { Middelbare docenten transport-, sportvakken } \\
\text { Middelbare agrarische beroepen } \\
\text { Middelbare wiskundige, natuurwetenschappelijke beroepen } \\
\text { Middelbare technische beroepen } \\
\text { Middelbare transportberoepen } \\
\text { Middelbare (para)medische beroepen } \\
\text { Middelbare administratieve, commerciële beroepen } \\
\text { Middelbare juridische, bestuurlijke beveiligingsberoepen } \\
\text { Middelbare taalkundige, culturele beroepen } \\
\text { Middelbare beroepen mbt gedrag en maatschappij } \\
\text { Middelbare verzorgende beroepen } \\
\text { Hogere pedagogische beroepen } \\
\text { Hogere landbouwkundige beroepen } \\
\text { Hogere wiskundige, natuurwetenschappelijke beroepen } \\
\text { Hogere technische beroepen } \\
\text { Hogere transportberoepen } \\
\text { Hogere (para)medische beroepen } \\
\text { Hogere administratieve, commerciële, economische beroepen } \\
\text { Hogere juridische, bestuurlijke, beveiligingsberoepen } \\
\text { Hogere taalkundige, culturele beroepen } \\
\text { Hogere beroepen mbt gedrag en maatschappij } \\
\text { Hogere verzorgende beroepen } \\
\text { Managers (HBO werk- en denkniveau) } \\
\text { Wetenschappelijke pedagogische beroepen } \\
\text { Wetenschappelijke landbouwkundige beroepen } \\
\text { Wetenschappelijke wiskundige, natuurwetenschappelijke beroepen } \\
\text { Wetenschappelijke technische beroepen } \\
\text { Wetenschappelijke (para)medische beroepen } \\
\text { Wetenschappelijke economische,administratieve beroepen } \\
\text { Wetenschappelijke juridische, bestuurlijke beroepen } \\
\text { Wetenschappelijke beroepen mbt gedrag en maatschappij } \\
\text { Managers (wetenschappelijk werk- en denkniveau) }\end{array}$ & $\begin{array}{r}48 \\
- \\
- \\
38 \\
- \\
52 \\
60 \\
74 \\
47 \\
44 \\
55 \\
- \\
60 \\
57 \\
62 \\
77 \\
70 \\
63 \\
68 \\
59 \\
49 \\
59 \\
52 \\
65 \\
55 \\
77 \\
77 \\
69 \\
78 \\
87 \\
67 \\
75 \\
66 \\
86 \\
73 \\
71 \\
80 \\
84 \\
85 \\
82 \\
78 \\
85\end{array}$ & $\begin{array}{l}\text { erg laag } \\
\text { laag } \\
\text { erg laag } \\
\text { erg laag } \\
\text { gemiddeld } \\
\text { laag } \\
\text { gemiddeld } \\
\text { gemiddeld } \\
\text { erg laag } \\
\text { erg laag } \\
\text { laag } \\
\text { erg laag } \\
\text { gemiddeld } \\
\text { laag } \\
\text { gemiddeld } \\
\text { hoog } \\
\text { gemiddeld } \\
\text { gemiddeld } \\
\text { gemiddeld } \\
\text { gemiddeld } \\
\text { laag } \\
\text { gemiddeld } \\
\text { laag } \\
\text { gemiddeld } \\
\text { laag } \\
\text { hoog } \\
\text { hoog } \\
\text { gemiddeld } \\
\text { hoog } \\
\text { erg hoog } \\
\text { gemiddeld } \\
\text { gemiddeld } \\
\text { gemiddeld } \\
\text { erg hoog } \\
\text { gemiddeld } \\
\text { hoog } \\
\text { gemiddeld } \\
\text { hoog } \\
\text { hoog } \\
\text { erg hoog } \\
\text { hoog } \\
\text { hoog } \\
\text { erg hoog }\end{array}$ \\
\hline
\end{tabular}

Bron: CBS/ROA 
Tabel 3.11

Mate van informatisering naar beroepsgroep, 1996*

\begin{tabular}{lll}
\hline Beroepsgroep & $\% \quad$ typering
\end{tabular}

PEDAGOGISCHE BEROEPEN

Leraar basisonderwijs

Docenten exacte, medische en verzorgende vakken ( $2 e$ graads)

Docenten exacte, medische en verzorgende vakken (1e graads)

Docenten landbouw en techniek (2e graads)

Docenten landbouw en techniek (1e graads)

Docenten economisch-administratieve vakken ( $2 \mathrm{e}$ graads)

Docenten economisch-administratieve vakken (1e graads)

Docenten talen en expressie

Docenten letteren (1e graads)

Docenten sociale vakken ( 2 e graads)

Docenten sociale vakken (1e graads)

Docenten 2 e graads zonder specialisatie

Docent 1 e graads zonder specialisatie

Onderwijskundig medewerkers

Onderwijskundigen en pedagogen

Rij-instructeurs

Zweminstructeurs

Sportinstructeurs

ypering

\section{CULTURELE BEROEPEN}

Tolken, vertalers en schrijvers

Bibliotheekassistenten

Bibliothecarissen

Grafisch ontwerpers

Kunstenaars

Geestelijk verzorgers

Geestelijken

Journalisten

Taalkundigen

gemiddeld

gemiddeld

gemiddeld

gemiddeld

gemiddeld

gemiddeld

hoog

laag

gemiddeld

laag

gemiddeld

gemiddeld

gemiddeld

gemiddeld

gemiddeld

laag

laag

laag

\section{AGRARISCHE BEROEPEN}

Agrarische hulparbeiders

Agrarische arbeiders

Agrarische vakkrachten

Milieuhygiënisten en agrarisch vertegenwoordigers

Landbouwkundigen

Landbouwmachinebestuurders en vissers

Agrarische bedrijfshoofden

gemiddeld

hoog

erg hoog

hoog

gemiddeld

gemiddeld

gemiddeld

erg hoog

hoog

\section{TECHNISCHE EN INDUSTRIEBEROEPEN}

Productiemedewerkers

Laboratorium-assistenten

Laboranten

Technisch analisten

Natuurwetenschappers

Conciërges

Hoofden technische dienst

Werktuigbouwkundigen

Bouwvakkers

Aannemers en installateurs

Architecten en bouwkundig projectleiders

Weg- en waterbouwkundigen

Weg- en waterbouwkundige arbeiders

Weg-en waterbouwkundige vakkrachten

Weg-en waterbouwkundig ontwerpers en projectleiders

Metaalarbeiders

Bankwerkers en lassers

Bedrijfshoofden metaalbewerking

Assembleurs

Monteurs

Werktuigbouwkundig ontwerpers en hoofden technische dienst

erg laag

erg laag

laag

gemiddeld

erg hoog

erg laag

laag 
Tabel 3.11 (vervolg)

Mate van informatisering naar beroepsgroep, 1996

\begin{tabular}{|c|c|c|}
\hline Beroepsgroep & $\%$ & typering \\
\hline $\begin{array}{l}\text { Elektronicamonteurs } \\
\text { Monteurs en controleurs elektrotechnische producten } \\
\text { Elektromonteurs } \\
\text { Elektrotechnisch ontwerpers en bedrijfshoofden } \\
\text { Elektrotechnici } \\
\text { Grafisch productiepersoneel } \\
\text { Grafische vakkrachten } \\
\text { Mechanisch operators } \\
\text { Procesoperators } \\
\text { Procestechnologen } \\
\text { Materiaalkundigen } \\
\text { Confectie-arbeiders } \\
\text { Schoen- en kleermakers }\end{array}$ & $\begin{array}{l}81 \\
42 \\
42 \\
99 \\
93 \\
56 \\
49 \\
26 \\
73 \\
86 \\
89 \\
- \\
-\end{array}$ & $\begin{array}{l}\text { gemiddeld } \\
\text { laag } \\
\text { laag } \\
\text { erg hoog } \\
\text { hoog } \\
\text { gemiddeld } \\
\text { gemiddeld } \\
\text { laag } \\
\text { gemiddeld } \\
\text { gemiddeld } \\
\text { hoog } \\
\text { erg laag } \\
\text { gemiddeld }\end{array}$ \\
\hline \multicolumn{3}{|l|}{ TRANSPORTBEROEPEN } \\
\hline $\begin{array}{l}\text { Laders en lossers } \\
\text { Chauffeurs } \\
\text { Schippers en conducteurs } \\
\text { Vliegers, scheepskapiteins en leidinggevenden transport } \\
\text { Stewards }\end{array}$ & $\begin{array}{r}29 \\
7 \\
69 \\
86 \\
-\end{array}$ & $\begin{array}{l}\text { laag } \\
\text { erg laag } \\
\text { gemiddeld } \\
\text { gemiddeld } \\
\text { laag }\end{array}$ \\
\hline \multicolumn{3}{|l|}{ MEDISCHE EN PARAMEDISCHE BEROEPEN } \\
\hline $\begin{array}{l}\text { Verpleeghulpen en leerling-verpleegkundigen } \\
\text { Verplegenden en doktersassistenten } \\
\text { Therapeuten en verpleegkundigen } \\
\text { Artsen } \\
\text { Apothekersassistenten en medisch laboranten } \\
\text { Medisch analisten } \\
\text { Apothekers } \\
\text { Afdelingshoofden zorginstelling }\end{array}$ & $\begin{array}{r}50 \\
46 \\
69 \\
77 \\
92 \\
71\end{array}$ & $\begin{array}{l}\text { erg laag } \\
\text { gemiddeld } \\
\text { gemiddeld } \\
\text { gemiddeld } \\
\text { gemiddeld } \\
\text { hoog } \\
\text { hoog } \\
\text { gemiddeld }\end{array}$ \\
\hline
\end{tabular}

\section{ECONOMISCH-ADMINISTRATIEVE BEROEPEN}

Kantoorhulpen, inpakkers en colporteurs

Ondersteunende administratieve hulpkrachten

Bedrijfshoofden

Economen

Productieplanners

Organisatie-adviseurs

Organisatiedeskundigen

Receptionisten en administratieve employés

Boekhouders en secretaresses

Assistent accountants

Accountants

Verzekeringsagenten

Commercieel employés

Commercieel medewerkers

Technisch-commercieel employés

Technisch-bedrijfskundig medewerkers

Juridisch en fiscaal medewerkers

Juridisch, bestuurlijk medewerkers

Juristen

Administratieve transportemployés

Leidinggevenden

Managers

Medisch secretaresses

laag

gemiddeld

gemiddeld

hoog

gemiddeld

hoog

hoog

gemiddeld

erg hoog

erg hoog

erg hoog

hoog

gemiddeld

hoog

gemiddeld

hoog

hoog

hoog

hoog

gemiddeld

gemiddeld

gemiddeld

erg hoog

\section{INFORMATICABEROEPEN}

Programmeurs

Systeemanalisten

Informatici

Technisch systeemanalisten 
Tabel 3.11 (vervolg)

Mate van informatisering naar beroepsgroep, 1996

\begin{tabular}{lll}
\hline Beroepsgroep & $\% \quad$ typering
\end{tabular}

SOCIAAL-CULTURELE BEROEPEN

Activiteitenbegeleiders en medewerkers arbeidsbemiddeling

Sociaal-cultureel werkers

Sociale raadslieden en hoofden personeelszaken

Sociaal-wetenschappelijk medewerkers

Sociaal-wetenschappelijk onderzoekers

$\begin{aligned} 55 & \text { gemiddeld } \\ 81 & \text { gemiddeld } \\ 80 & \text { gemiddeld } \\ 100 & \text { erg hoog } \\ 84 & \text { gemiddeld }\end{aligned}$

VERZORGENDE EN DIENSTVERLENENDE BEROEPEN

Vakkenvullers

Interieurverzorgers

Verkopers

Winkeliers

Hulpkrachten horeca en verzorging

Ziekenverzorgenden

Verzorgend personeel

Café- en snackbarhouders

Bedrijfshoofden horeca

Bakkers en slagers

$\begin{aligned}- & \text { laag } \\ - & \text { erg laag } \\ 27 & \text { laag } \\ 56 & \text { gemiddeld } \\ 7 & \text { erg laag } \\ 10 & \text { erg laag } \\ 15 & \text { erg laag } \\ - & \text { laag } \\ 42 & \text { laag } \\ - & \text { laag }\end{aligned}$

OPENBARE ORDE- EN VEILIGHEIDSBEROEPEN

Adspirant politieagenten, soldaten en beveiligingshulpkrachten

Politieagenten, onderofficieren en beveiligingsemployés

Politie-inspecteurs en officieren

63 gemiddeld

Brandweerlieden

Bron: CBS/ROA

* Onder 'informatisering' wordt verstaan het percentage werknemers dat gewoonlijk of soms met een computer werkt. 
Tabel 3.12

Mate van informatisering naar beroepssegment, 1996*

\begin{tabular}{|c|c|c|}
\hline Beroepssegment & $\%$ & typering \\
\hline $\begin{array}{l}\text { Elementaire beroepen } \\
\text { Lagere niet-specialistische beroepen } \\
\text { Lagere docenten sportvakken } \\
\text { Lagere agrarische beroepen } \\
\text { Lagere wiskundige, natuurwetenschappelijke beroepen } \\
\text { Lagere technische beroepen } \\
\text { Lagere transportberoepen } \\
\text { Lagere (para)medische beroepen } \\
\text { Lagere administratieve, commerciële beroepen } \\
\text { Lagere beveiligingsberoepen } \\
\text { Lagere verzorgende beroepen } \\
\text { Middelbare docenten transport-, sportvakken } \\
\text { Middelbare agrarische beroepen } \\
\text { Middelbare wiskundige, natuurwetenschappelijke beroepen } \\
\text { Middelbare technische beroepen } \\
\text { Middelbare transportberoepen } \\
\text { Middelbare (para)medische beroepen } \\
\text { Middelbare administratieve, commerciële beroepen } \\
\text { Middelbare juridische, bestuurlijke beveiligingsberoepen } \\
\text { Middelbare taalkundige, culturele beroepen } \\
\text { Middelbare beroepen mbt gedrag en maatschappij } \\
\text { Middelbare verzorgende beroepen } \\
\text { Hogere pedagogische beroepen } \\
\text { Hogere landbouwkundige beroepen } \\
\text { Hogere wiskundige, natuurwetenschappelijke beroepen } \\
\text { Hogere technische beroepen } \\
\text { Hogere transportberoepen } \\
\text { Hogere (para)medische beroepen } \\
\text { Hogere administratieve, commerciële, economische beroepen } \\
\text { Hogere juridische, bestuurlijke, beveiligingsberoepen } \\
\text { Hogere taalkundige, culturele beroepen } \\
\text { Hogere beroepen mbt gedrag en maatschappij } \\
\text { Hogere verzorgende beroepen } \\
\text { Managers (HBO werk-en denkniveau) } \\
\text { Wetenschappelijke pedagogische beroepen } \\
\text { Wetenschappelijke landbouwkundige beroepen } \\
\text { Wetenschappelijke wiskundige, natuurwetenschappelijke beroepen } \\
\text { Wetenschappelijke technische beroepen } \\
\text { Wetenschappelijke (para)medische beroepen } \\
\text { Wetenschappelijke economische,administratieve beroepen } \\
\text { Wetenschappelijke juridische, bestuurlijke beroepen } \\
\text { Wetenschappelijke beroepen mbt gedrag en maatschappij } \\
\text { Managers (wetenschappelijk werk-en denkniveau) } \\
\text { Hathen }\end{array}$ & $\begin{array}{r}16 \\
70 \\
- \\
7 \\
- \\
16 \\
7 \\
- \\
58 \\
63 \\
7 \\
- \\
41 \\
88 \\
40 \\
70 \\
48 \\
89 \\
93 \\
94 \\
55 \\
17 \\
49 \\
81 \\
93 \\
88 \\
86 \\
53 \\
95 \\
93 \\
77 \\
85 \\
71 \\
82 \\
71 \\
100 \\
97 \\
91 \\
72 \\
97 \\
92 \\
84 \\
76\end{array}$ & $\begin{array}{l}\text { laag } \\
\text { gemiddeld } \\
\text { laag } \\
\text { erg laag } \\
\text { gemiddeld } \\
\text { laag } \\
\text { erg laag } \\
\text { erg laag } \\
\text { gemiddeld } \\
\text { gemiddeld } \\
\text { erg laag } \\
\text { laag } \\
\text { laag } \\
\text { hoog } \\
\text { laag } \\
\text { gemiddeld } \\
\text { gemiddeld } \\
\text { hoog } \\
\text { hoog } \\
\text { hoog } \\
\text { gemiddeld } \\
\text { laag } \\
\text { gemiddeld } \\
\text { gemiddeld } \\
\text { hoog } \\
\text { hoog } \\
\text { gemiddeld } \\
\text { gemiddeld } \\
\text { hoog } \\
\text { hoog } \\
\text { gemiddeld } \\
\text { gemiddeld } \\
\text { gemiddeld } \\
\text { gemiddeld } \\
\text { gemiddeld } \\
\text { erg hoog } \\
\text { erg hoog } \\
\text { hoog } \\
\text { gemiddeld } \\
\text { erg hoog } \\
\text { hoog } \\
\text { gemiddeld } \\
\text { gemiddeld }\end{array}$ \\
\hline
\end{tabular}

Bron: CBS/ROA

* Onder 'informatisering' wordt verstaan het percentage werknemers dat gewoonlijk of soms met een computer werkt. 
Tabel 3.13

Verwachte netto baancreatie naar beroepssegment, 1997-2002

\begin{tabular}{|c|c|c|}
\hline Beroepssegment & aantal & $\%$ \\
\hline $\begin{array}{l}\text { Elementaire beroepen } \\
\text { Lagere niet-specialistische beroepen } \\
\text { Lagere docenten sportvakken } \\
\text { Lagere agrarische beroepen } \\
\text { Lagere wiskundige, natuurwetenschappelijke beroepen } \\
\text { Lagere technische beroepen } \\
\text { Lagere transportberoepen } \\
\text { Lagere (para)medische beroepen } \\
\text { Lagere administratieve, commerciële beroepen } \\
\text { Lagere beveiligingsberoepen } \\
\text { Lagere verzorgende beroepen } \\
\text { Middelbare docenten transport-, sportvakken } \\
\text { Middelbare agrarische beroepen } \\
\text { Middelbare wiskundige, natuurwetenschappelijke beroepen } \\
\text { Middelbare technische beroepen } \\
\text { Middelbare transportberoepen } \\
\text { Middelbare (para)medische beroepen } \\
\text { Middelbare administratieve, commerciële beroepen } \\
\text { Middelbare juridische, besturlijke beveiligingsberoepen } \\
\text { Middelbare taalkundige, culturele beroepen } \\
\text { Middelbare beroepen mbt gedrag en maatschappij } \\
\text { Middelbare verzorgende beroepen } \\
\text { Hogere pedagogische beroepen } \\
\text { Hogere landbouwkundige beroepen } \\
\text { Hogere wiskundige, natuurwetenschappelijke beroepen } \\
\text { Hogere technische beroepen } \\
\text { Hogere transportberoepen } \\
\text { Hogere (para)medische beroepen } \\
\text { Hogere administratieve, commerciële, economische beroepen } \\
\text { Hogere juridische, bestuurlijke, beveiligingsberoepen } \\
\text { Hogere taalkundige, culturele beroepen } \\
\text { Hogere beroepen mbt gedrag en maatschappij } \\
\text { Hogere verzorgende beroepen } \\
\text { Managers (HBO werk-en denkniveau) } \\
\text { Wetenschappelijke pedagogische beroepen } \\
\text { Wetenschappelijke landbouwkundige beroepen } \\
\text { Wetenschappelijke wiskundige, natuurwetenschappelijke beroepen } \\
\text { Wetenschappelijke technische beroepen } \\
\text { Wetenschappelijke (para)medische beroepen } \\
\text { Wetenschappelijke economische,administratieve beroepen } \\
\text { Wetenschappelijke juridische, bestuurlijke beroepen } \\
\text { Wetenschappelijke beroepen mbt gedrag en maatschappij } \\
\text { Managers (wetenschappelijk werk- en denkniveau) }\end{array}$ & $\begin{array}{r}45.700 \\
1.400 \\
300 \\
-2.300 \\
300 \\
15.900 \\
23.900 \\
-100 \\
11.600 \\
3.900 \\
6.300 \\
700 \\
-5.300 \\
1.000 \\
33.900 \\
2.300 \\
29.600 \\
150.400 \\
-1.800 \\
2.100 \\
9.800 \\
35.600 \\
1.300 \\
5.200 \\
1.400 \\
7.200 \\
2.000 \\
1.600 \\
77.400 \\
600 \\
5.400 \\
9.400 \\
100 \\
6.600 \\
10.600 \\
1.000 \\
1.700 \\
7.100 \\
5.800 \\
20.400 \\
5.000 \\
8.300 \\
7.400\end{array}$ & $\begin{array}{r}10 \\
13 \\
7 \\
-2 \\
10 \\
3 \\
10 \\
-1 \\
2 \\
9 \\
4 \\
4 \\
-4 \\
7 \\
5 \\
4 \\
13 \\
16 \\
-2 \\
8 \\
18 \\
15 \\
1 \\
33 \\
12 \\
6 \\
12 \\
1 \\
17 \\
3 \\
9 \\
9 \\
1 \\
15 \\
12 \\
20 \\
11 \\
15 \\
10 \\
26 \\
10 \\
18 \\
10\end{array}$ \\
\hline
\end{tabular}

Bron: ROA 
Tabel 3.14

Verwachte sectorale reallocatie naar beroepssegment, 1997-2002

\begin{tabular}{|c|c|c|}
\hline Beroepssegment & aantal & $\%$ \\
\hline Elementaire beroepen & 4.200 & 1 \\
\hline Lagere niet-specialistische beroepen & 0 & 0 \\
\hline Lagere docenten sportvakken & 0 & 0 \\
\hline Lagere agrarische beroepen & 5.800 & 5 \\
\hline Lagere wiskundige, natuurwetenschappelijke beroepen & 0 & 0 \\
\hline Lagere technische beroepen & 13.700 & 3 \\
\hline Lagere transportberoepen & 300 & 0 \\
\hline Lagere (para)medische beroepen & 100 & 1 \\
\hline Lagere administratieve, commerciële beroepen & 12.500 & 2 \\
\hline Lagere beveiligingsberoepen & 100 & 0 \\
\hline Lagere verzorgende beroepen & 5.100 & 3 \\
\hline Middelbare docenten transport-, sportvakken & 100 & 1 \\
\hline Middelbare agrarische beroepen & 1.100 & 1 \\
\hline Middelbare wiskundige, natuurwetenschappelijke beroepen & 100 & 1 \\
\hline Middelbare technische beroepen & 6.700 & 1 \\
\hline Middelbare transportberoepen & 100 & 0 \\
\hline Middelbare (para)medische beroepen & 200 & 0 \\
\hline Middelbare administratieve, commerciële beroepen & 0 & 0 \\
\hline Middelbare juridische, bestuurlijke beveiligingsberoepen & 900 & 1 \\
\hline Middelbare taalkundige, culturele beroepen & 300 & 1 \\
\hline Middelbare beroepen mbt gedrag en maatschappij & 0 & 0 \\
\hline Middelbare verzorgende beroepen & 100 & 0 \\
\hline Hogere pedagogische beroepen & 0 & 0 \\
\hline Hogere landbouwkundige beroepen & 200 & 1 \\
\hline Hogere wiskundige, natuurwetenschappelijke beroepen & 0 & 0 \\
\hline Hogere technische beroepen & 1.300 & 1 \\
\hline Hogere transportberoepen & 0 & 0 \\
\hline Hogere (para)medische beroepen & 200 & 0 \\
\hline Hogere administratieve, commerciële, economische beroepen & 1.800 & 0 \\
\hline Hogere juridische, bestuurlijke, beveiligingsberoepen & 400 & 2 \\
\hline Hogere taalkundige, culturele beroepen & 0 & 0 \\
\hline Hogere beroepen mbt gedrag en maatschappij & 0 & 0 \\
\hline Hogere verzorgende beroepen & 0 & 0 \\
\hline Managers (HBO werk- en denkniveau) & 0 & 0 \\
\hline Wetenschappelijke pedagogische beroepen & 0 & 0 \\
\hline Wetenschappelijke landbouwkundige beroepen & 0 & 0 \\
\hline Wetenschappelijke wiskundige, natuurwetenschappelijke beroepen & 100 & 1 \\
\hline Wetenschappelijke technische beroepen & 100 & 0 \\
\hline Wetenschappelijke (para)medische beroepen & 0 & 0 \\
\hline Wetenschappelijke economische,administratieve beroepen & 0 & 0 \\
\hline Wetenschappelijke juridische, bestuurlijke beroepen & 0 & 0 \\
\hline Wetenschappelijke beroepen mbt gedrag en maatschappij & 0 & 0 \\
\hline Managers (wetenschappelijk werk- en denkniveau) & 100 & 0 \\
\hline
\end{tabular}

Bron: ROA 


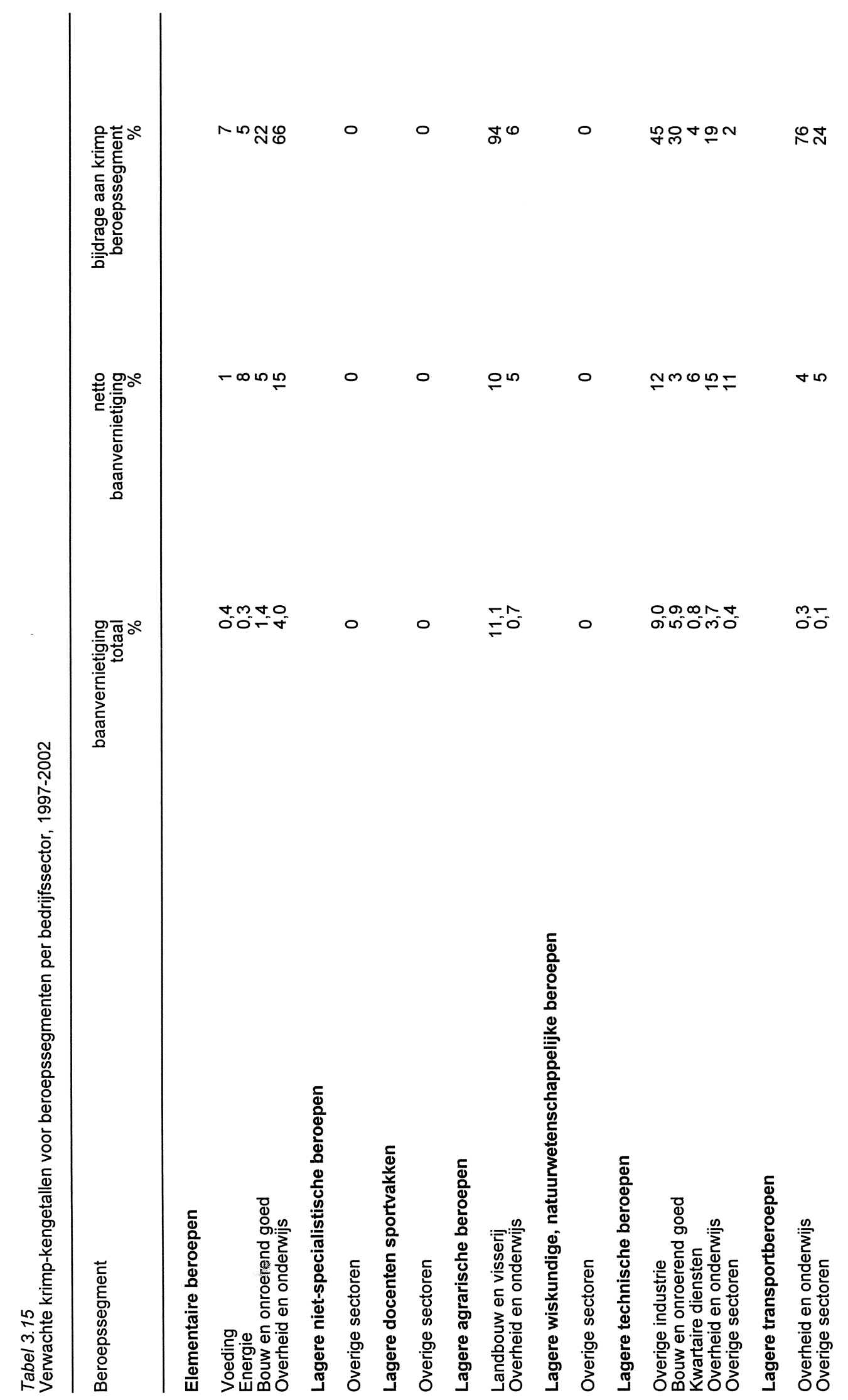




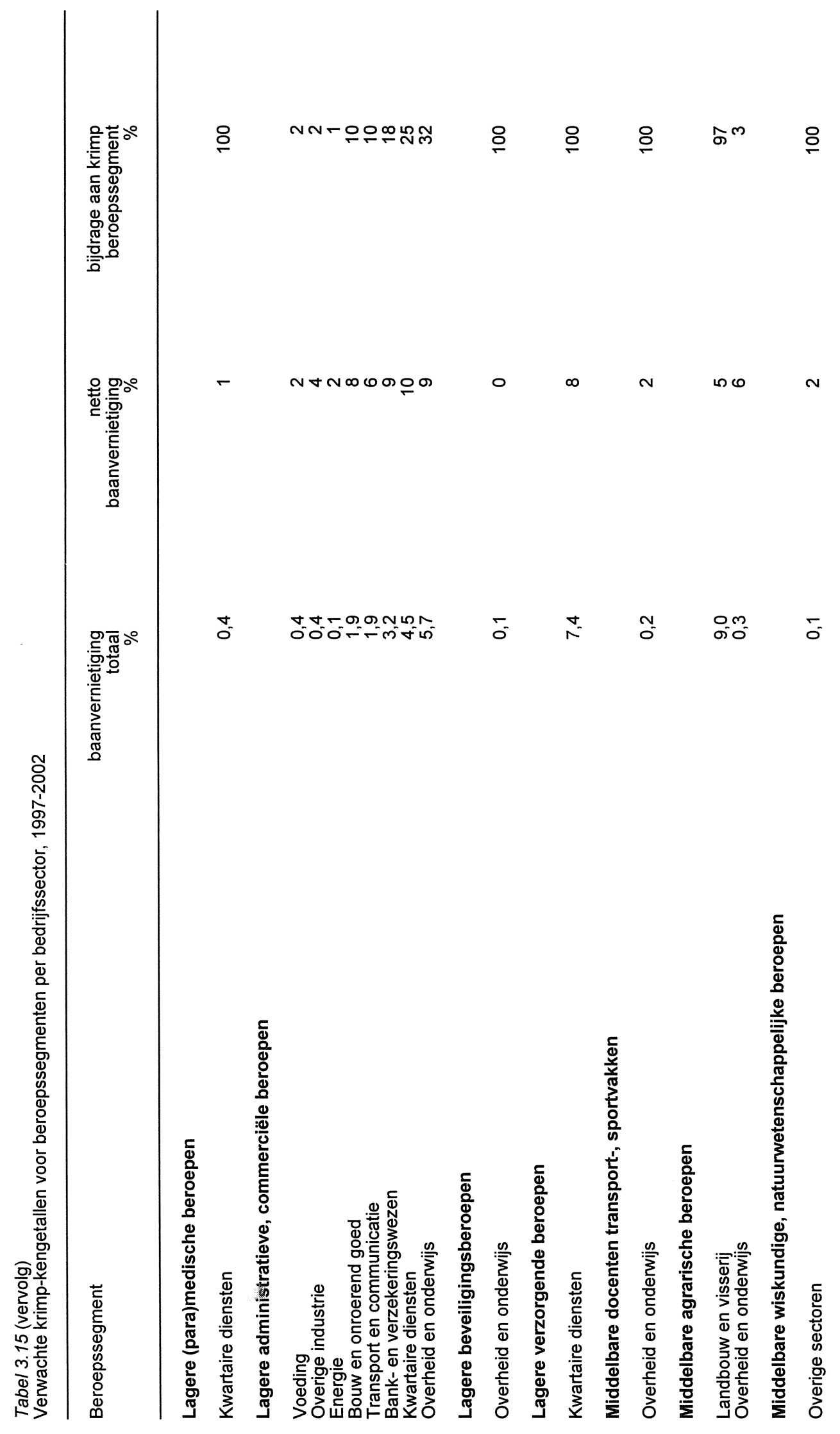




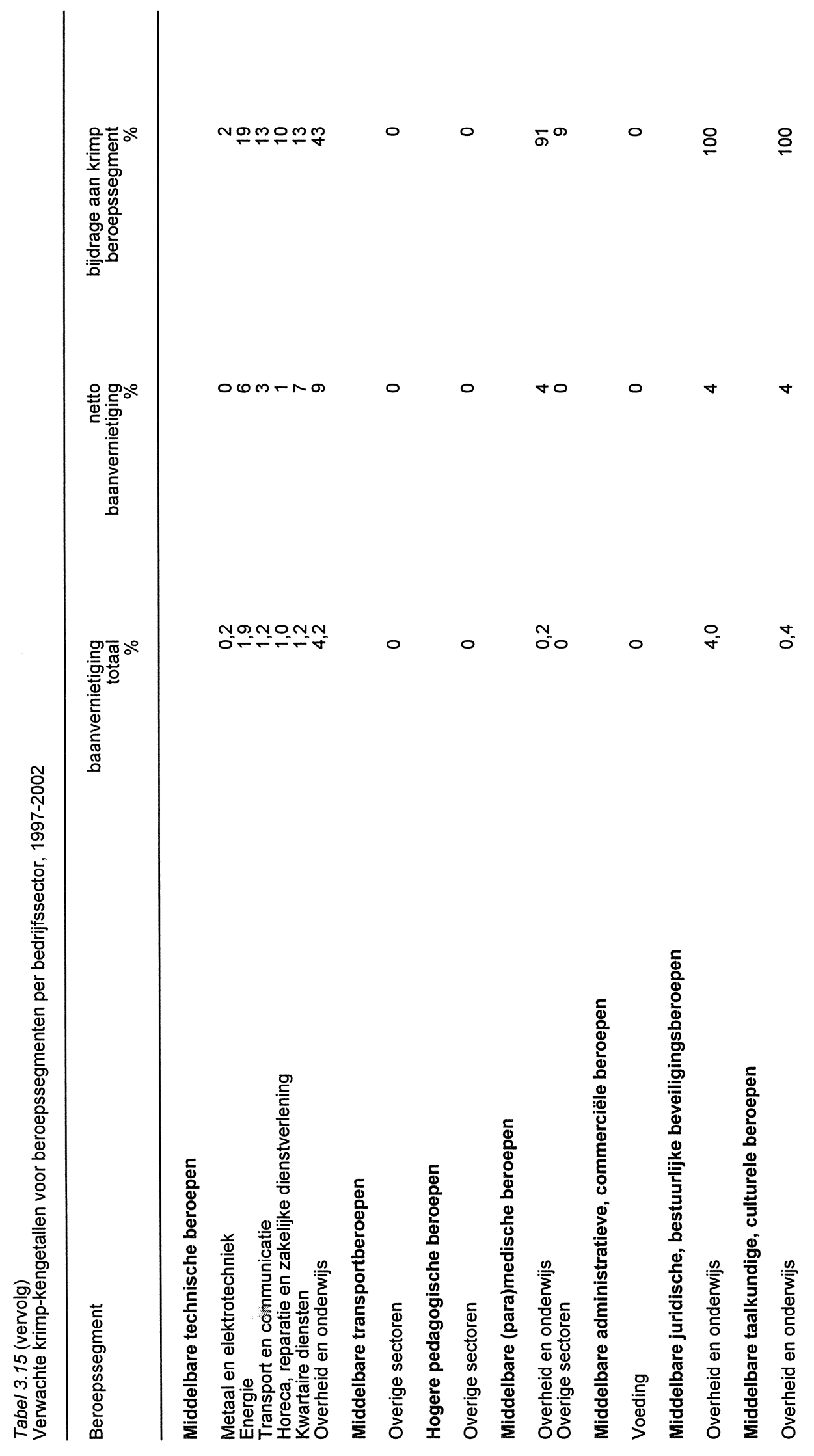




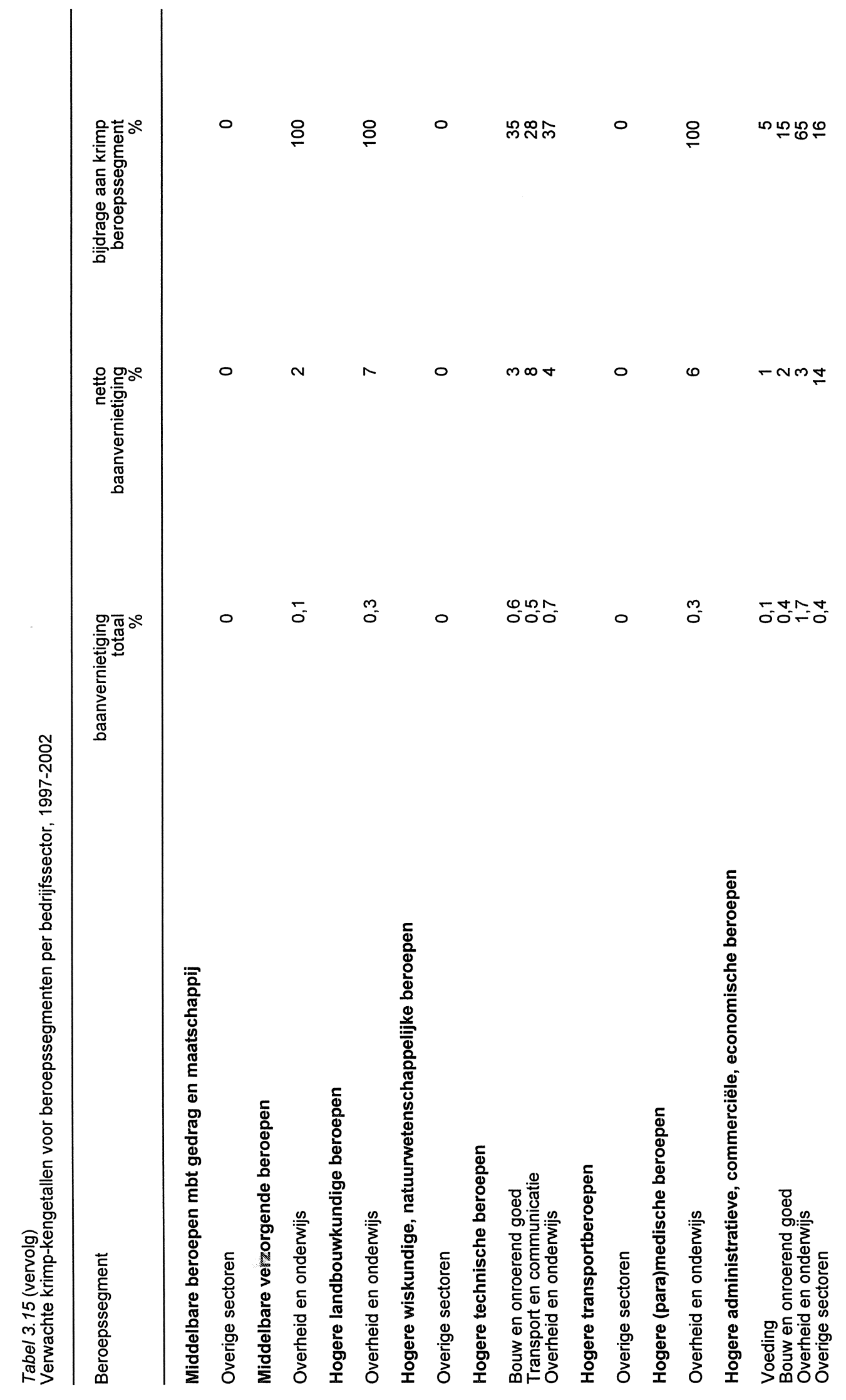




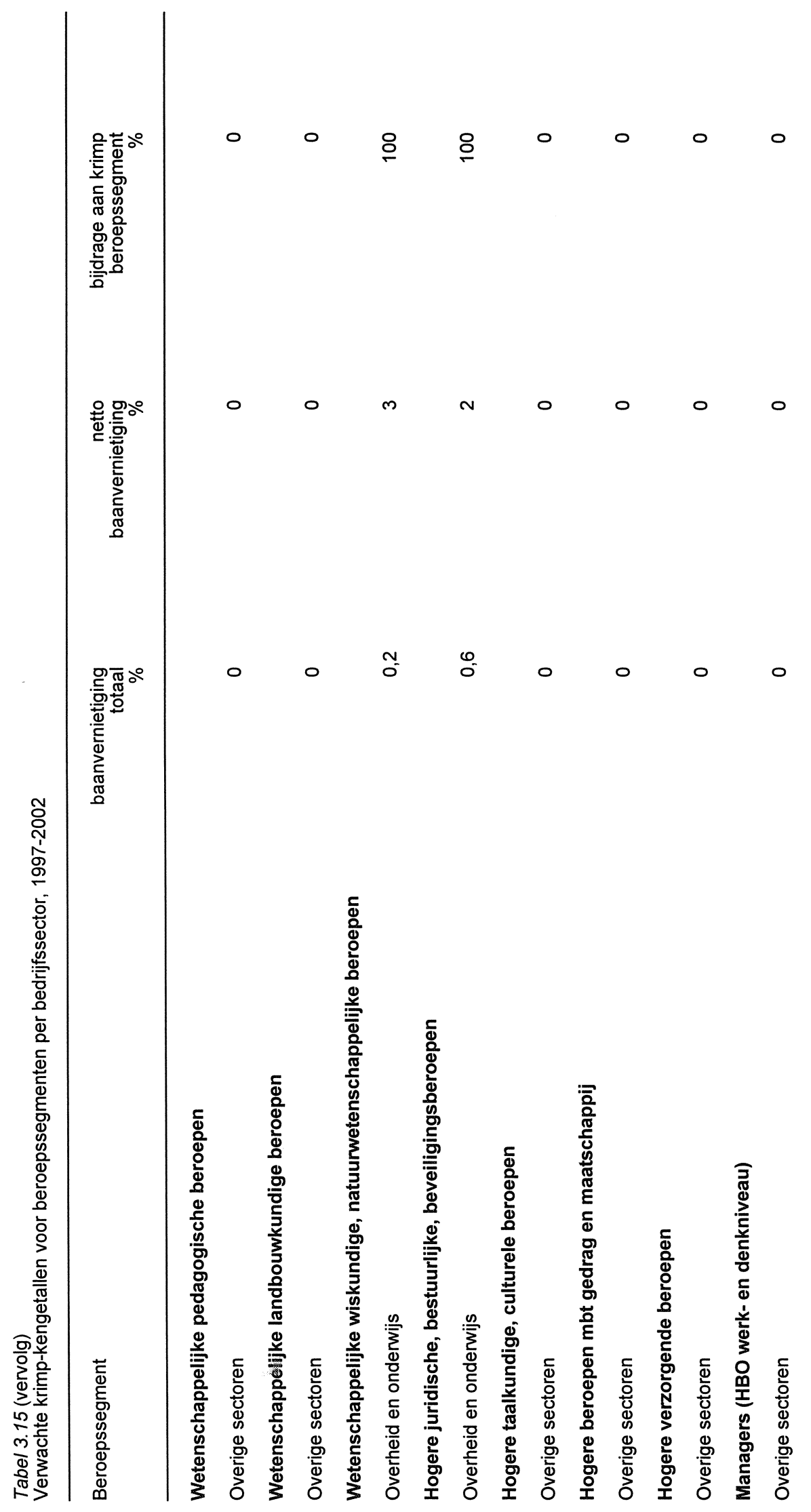




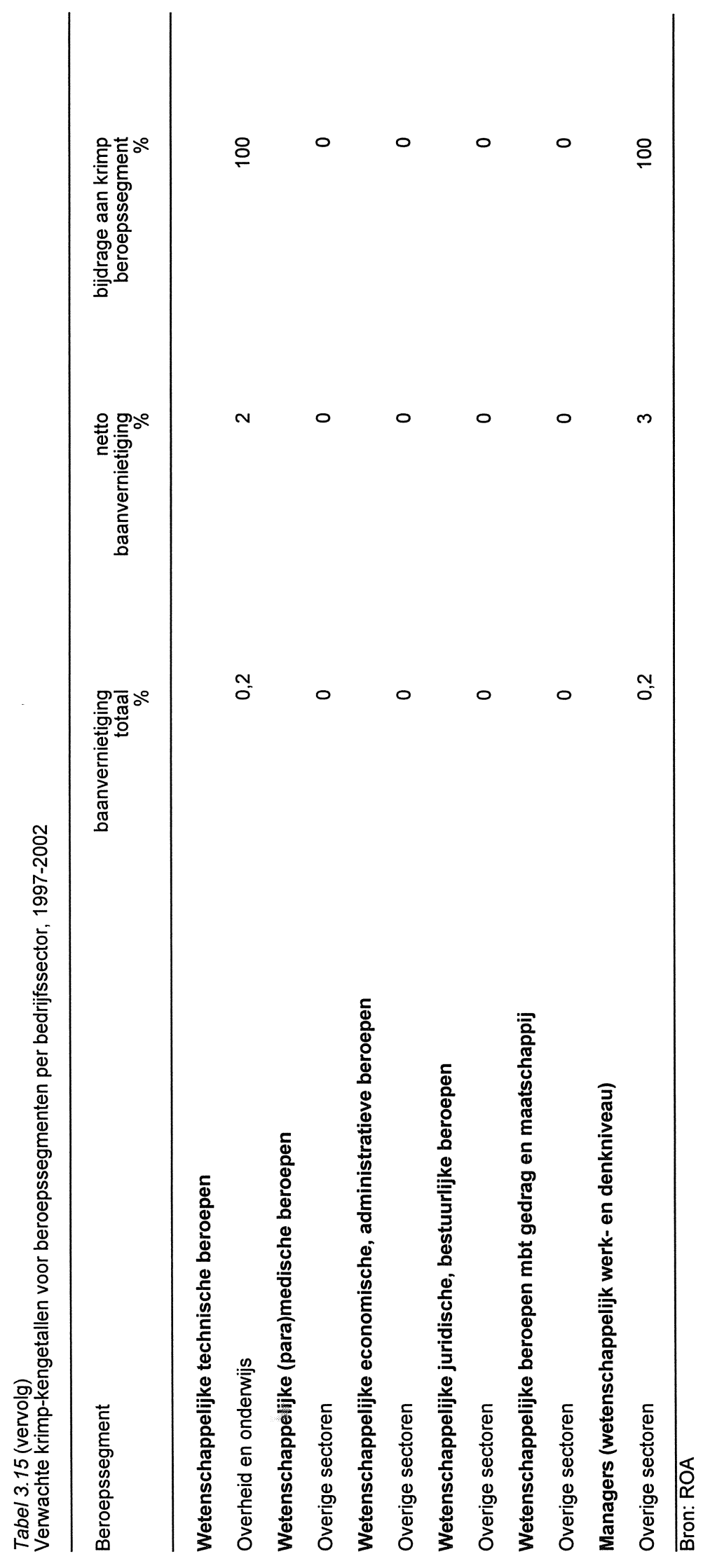




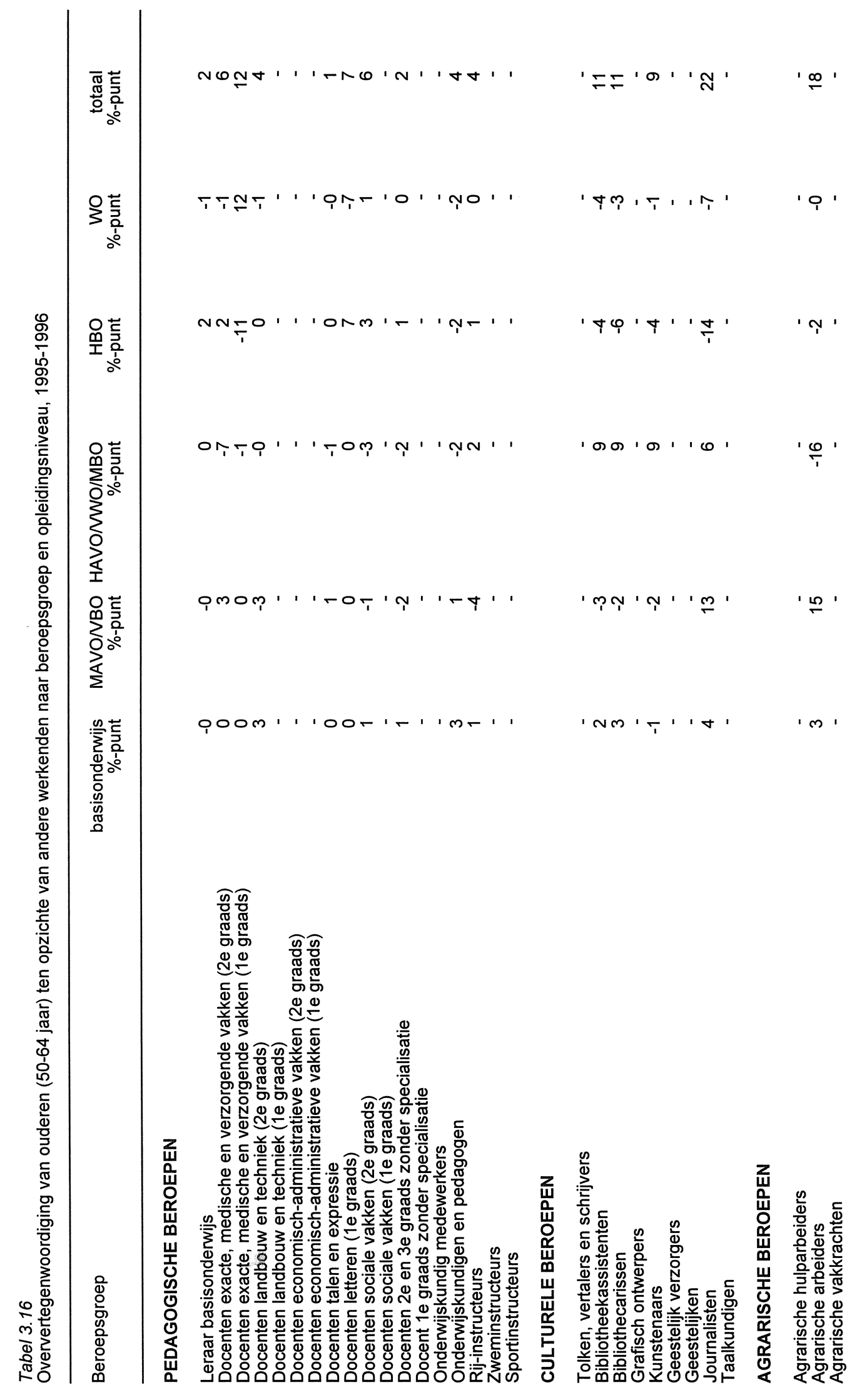




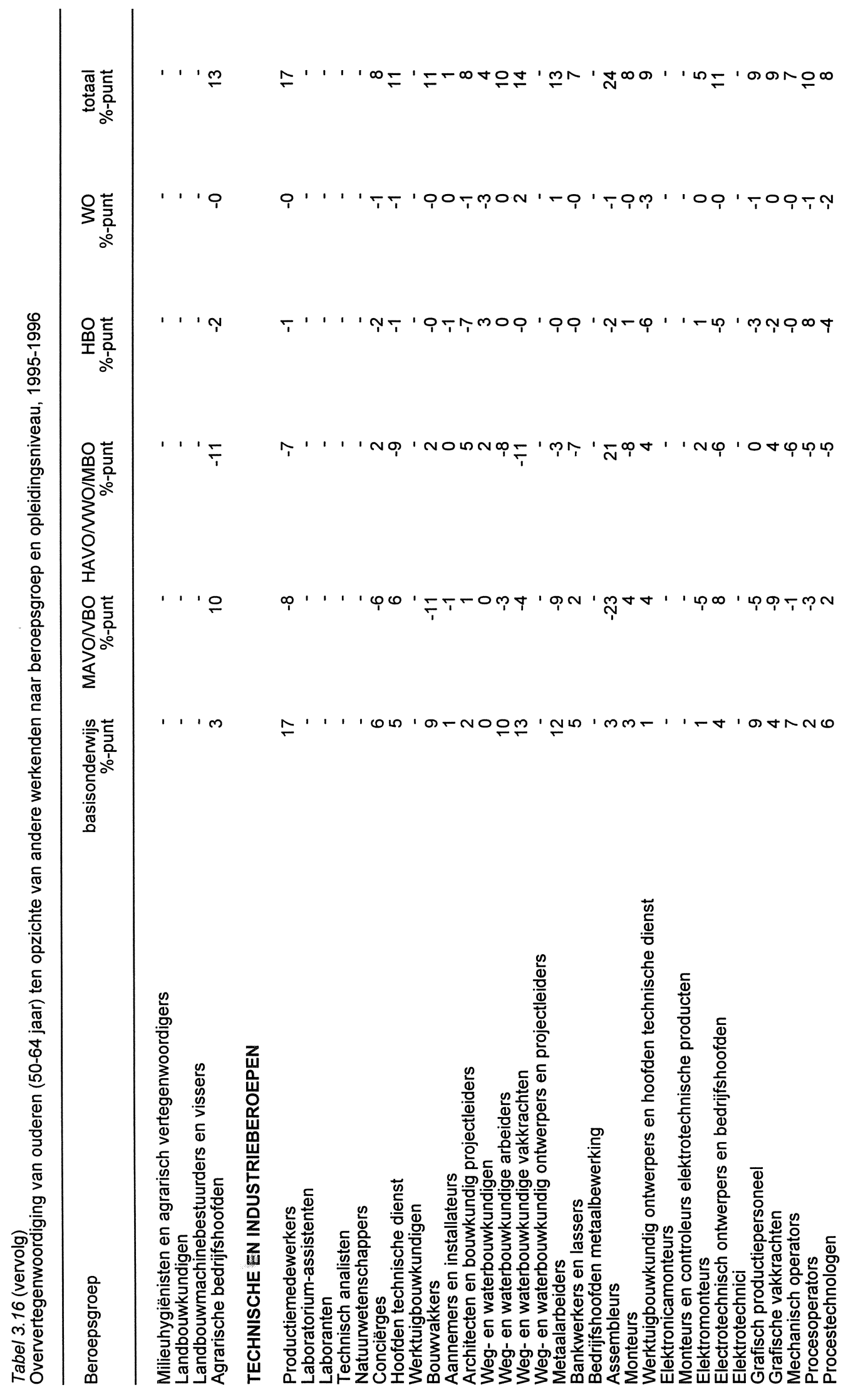




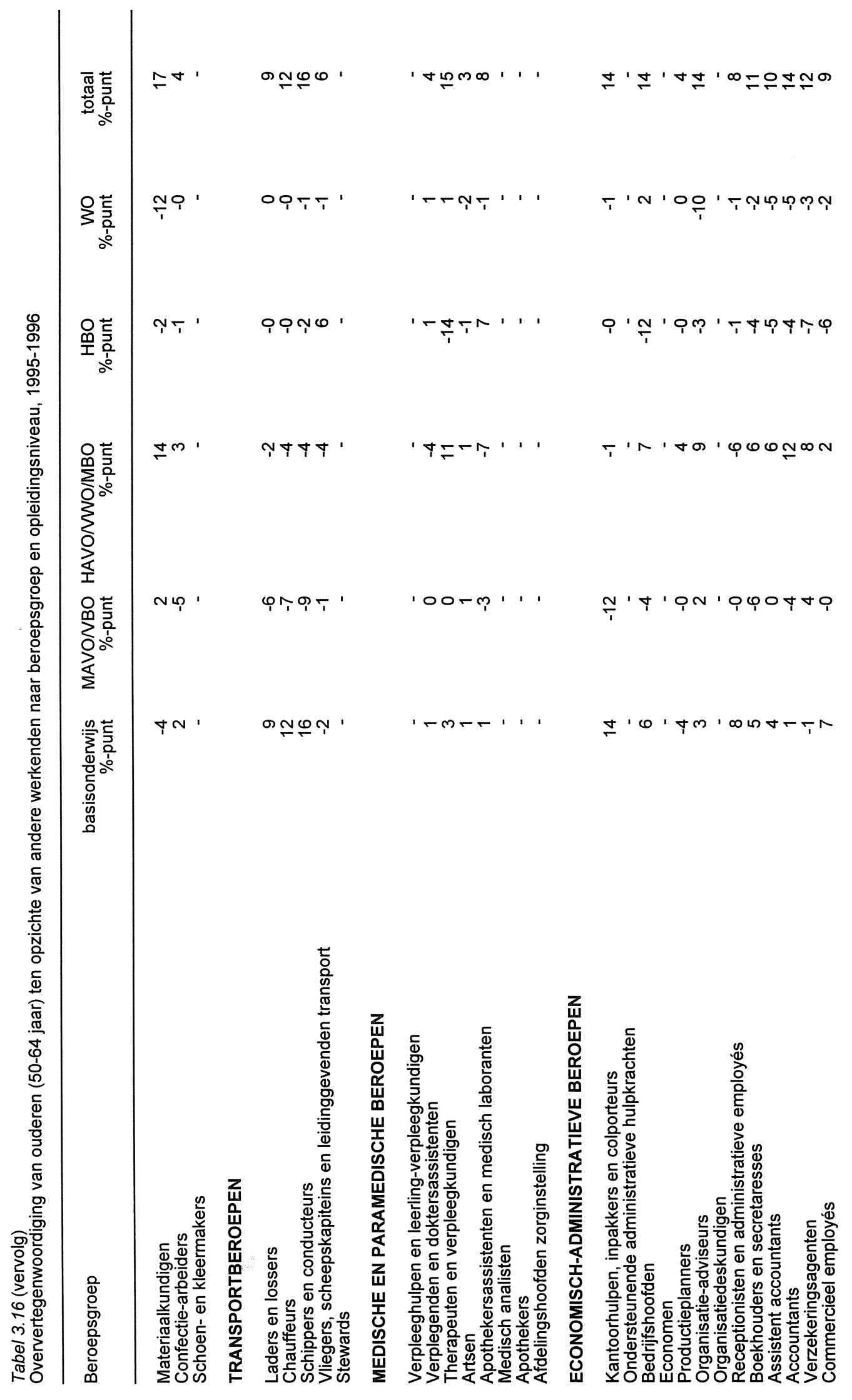




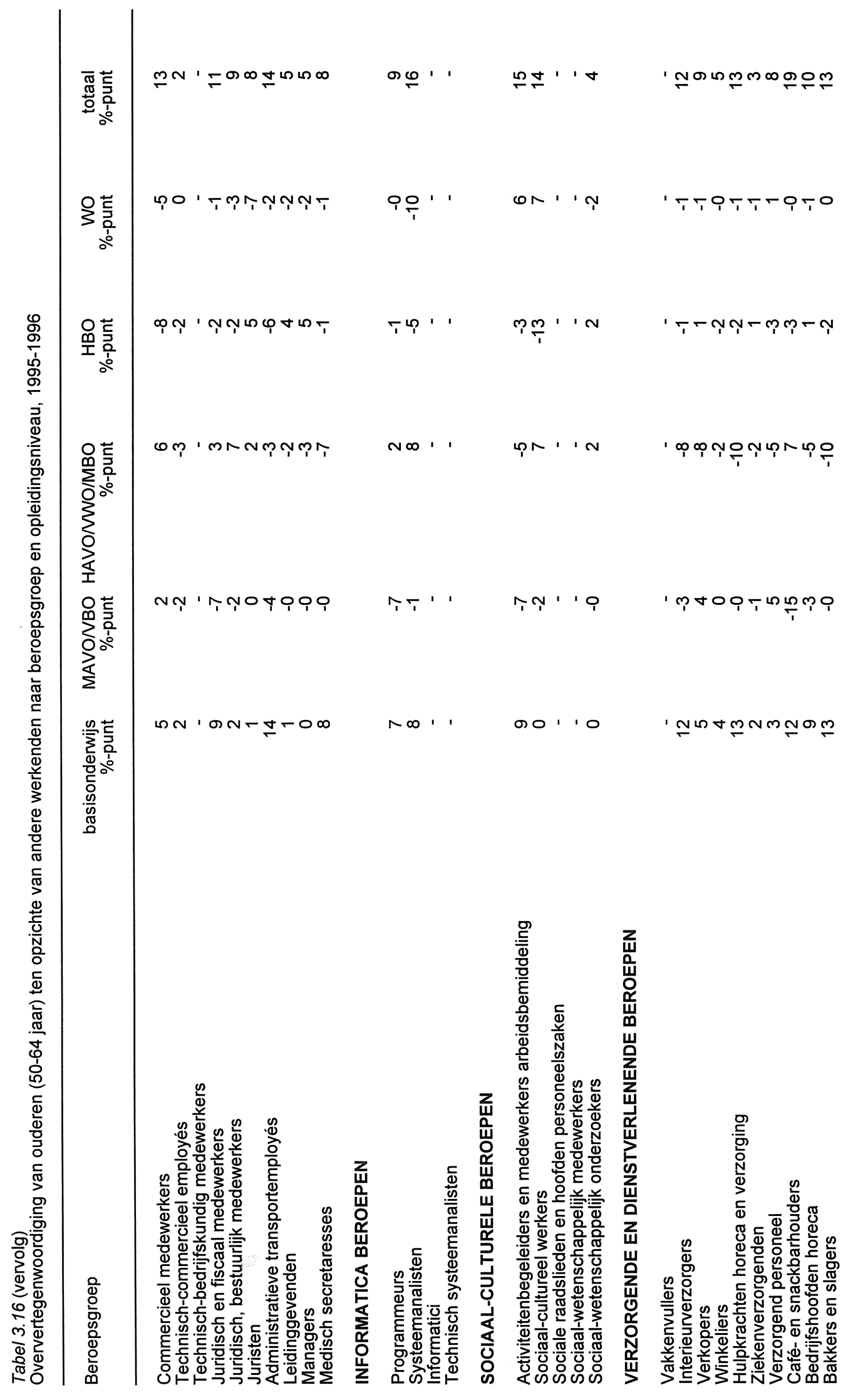




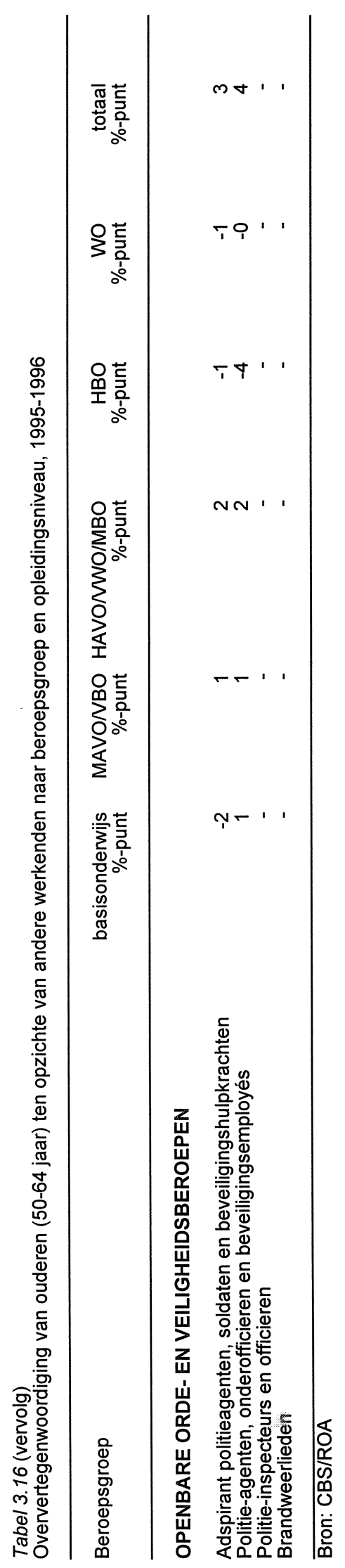


Tabel 3.17

Percentage werkenden dat deelneemt aan bedrijfsopleidingen, naar beroepssegment, gemiddelde 19951996

\begin{tabular}{|c|c|c|c|}
\hline Beroepssegment & $\%$ & typering & trend \\
\hline Elementaire beroepen & 2 & erg laag & fluctuerend \\
\hline Lagere niet-specialistische beroepen & - & - & dalend \\
\hline Lagere docenten sportvakken & - & - & dalend \\
\hline Lagere agrarische beroepen & 2 & erg laag & fluctuerend \\
\hline Lagere wiskundige, natuurwetenschappelijke beroepen & - & - & dalend \\
\hline Lagere technische beroepen & 5 & gemiddeld & fluctuerend \\
\hline Lagere transportberoepen & 2 & erg laag & fluctuerend \\
\hline Lagere (para)medische beroepen & $5 \overline{6}$ & erg hoog & dalend \\
\hline Lagere administratieve, commerciële beroepen & 3 & laag & dalend \\
\hline Lagere beveiligingsberoepen & 14 & erg hoog & dalend \\
\hline Lagere verzorgende beroepen & 5 & gemiddeld & fluctuerend \\
\hline Middelbare docenten transport-, sportvakken & - & - & fluctuerend \\
\hline Middelbare agrarische beroepen & - & - & dalend \\
\hline Middelbare wiskundige, natuurw. beroepen & - & - & fluctuerend \\
\hline Middelbare technische beroepen & 6 & hoog & fluctuerend \\
\hline Middelbare transportberoepen & 5 & gemiddeld & fluctuerend \\
\hline Middelbare (para)medische beroepen & 6 & hoog & fluctuerend \\
\hline Middelbare administratieve, commerciële beroepen & 5 & gemiddeld & sterk dalend \\
\hline Middelbare juridische, bestuurlijke beveiligingsberoepen & 9 & erg hoog & fluctuerend \\
\hline Middelbare taalkundige, culturele beroepen & - & - & fluctuerend \\
\hline Middelbare beroepen mbt gedrag en maatschappij & 6 & hoog & fluctuerend \\
\hline Middelbare verzorgende beroepen & 3 & laag. & sterk dalend \\
\hline Hogere pedagogische beroepen & 5 & gemiddeld & dalend \\
\hline Hogere landbouwkundige beroepen & - & - & fluctuerend \\
\hline Hogere wiskundige, natuurwetenschappelijke beroepen & - & - & fluctuerend \\
\hline Hogere technische beroepen & 6 & hoog & sterk dalend \\
\hline Hogere transportberoepen & - & - & fluctuerend \\
\hline Hogere (para)medische beroepen & 4 & gemiddeld & sterk dalend \\
\hline Hogere admin., commerciële, economische beroepen & 6 & hoog & dalend \\
\hline Hogere juridische, bestuurlijke, beveiligingsberoepen & - & - & fluctuerend \\
\hline Hogere taalkundige, culturele beroepen & - & - & fluctuerend \\
\hline Hogere beroepen mbt gedrag en maatschappij & 4 & gemiddeld & fluctuerend \\
\hline Hogere verzorgende beroepen & - & - & dalend \\
\hline Managers (HBO werk- en denkniveau) & 6 & hoog & sterk dalend \\
\hline Wetenschappelijke pedagogische beroepen & 3 & laag & fluctuerend \\
\hline Wetenschappelijke landbouwkundige beroepen & - & - & fluctuerend \\
\hline Wetenschappelijke wiskundige, natuurw. beroepen & - & - & sterk dalend \\
\hline Wetenschappelijke technische beroepen & - & gemiddeld & fluctuerend \\
\hline Wetenschappelijke (para)medische beroepen & - & laag & dalend \\
\hline Wetenschappelijke economische, admin. beroepen & 3 & laag & fluctuerend \\
\hline Wetenschappelijke juridische, bestuurlijke beroepen & - & gemiddeld & dalend \\
\hline Wetenschappelijke beroepen mbt gedrag en maatschappij & - & gemiddeld & fluctuerend \\
\hline Managers (wetenschappelijk werk-en denkniveau) & 4 & gemiddeld & fluctuerend \\
\hline
\end{tabular}

Bron: CBS/ROA 
Tabel 3.18

Employability-indicatoren naar beroepssegment, 1996

\begin{tabular}{|c|c|c|c|c|}
\hline Beroepssegment & $\begin{array}{c}\text { niet } \\
\text { mobiel } \\
\%\end{array}$ & $\begin{array}{c}\text { niet actief } \\
\text { zoekend } \\
\%\end{array}$ & $\begin{array}{c}\text { niet breed } \\
\text { inzetbaar } \\
\%\end{array}$ & $\begin{array}{c}\text { ervarings- } \\
\text { concentratie } \\
\%\end{array}$ \\
\hline Elementaire beroepen & - & - & _ & _ \\
\hline Lagere niet-specialistische beroepen & - & - & - & - \\
\hline Lagere docenten sportvakken & - & - & - & - \\
\hline Lagere agrarische beroepen & 67 & 92 & 12 & 21 \\
\hline Lagere wiskundige, natuurw. beroepen & - & - & - & - \\
\hline Lagere technische beroepen & 74 & 89 & 26 & 26 \\
\hline Lagere transportberoepen & 82 & 93 & 35 & 43 \\
\hline Lagere (para)medische beroepen & 88 & 100 & 50 & 33 \\
\hline Lagere admin., commerciële beroepen & 75 & 90 & 22 & 19 \\
\hline Lagere beveiligingsberoepen & 82 & 90 & 27 & 9 \\
\hline Lagere verzorgende beroepen & 71 & 89 & 35 & 20 \\
\hline Middelbare docenten transport-, sportvakken & - & - & - & - \\
\hline Middelbare agrarische beroepen & - & - & - & - \\
\hline Middelbare wiskundige, natuurw. beroepen & - & - & - & - \\
\hline Middelbare technische beroepen & 73 & 90 & 19 & 28 \\
\hline Middelbare transportberoepen & 90 & 85 & 20 & 20 \\
\hline Middelbare (para)medische beroepen & 85 & 90 & 37 & 24 \\
\hline Middelbare admin., commerciële beroepen & 65 & 90 & 22 & 19 \\
\hline Middelbare juridische, best. beveiligingsberoepen & 88 & 93 & 31 & 31 \\
\hline Middelbare taalkundige, culturele beroepen & 65 & 100 & 29 & 31 \\
\hline Middelbare beroepen mbt gedrag en maatschappij & 54 & 80 & 25 & 13 \\
\hline Middelbare verzorgende beroepen & 84 & 96 & 29 & 20 \\
\hline Hogere pedagogische beroepen & 88 & 96 & 34 & 46 \\
\hline Hogere landbouwkundige beroepen & - & - & - & - \\
\hline Hogere wiskundige, natuurw. beroepen & - & - & - & - \\
\hline Hogere technische beroepen & 70 & 90 & 16 & 19 \\
\hline Hogere transportberoepen & - & - & - & - \\
\hline Hogere (para)medische beroepen & 80 & 98 & 60 & 30 \\
\hline Hogere admin. commerciële, economische beroepen & 65 & 85 & 24 & 9 \\
\hline Hogere juridische, bestuurlijke, beveiligingsberoepen & 82 & 80 & 36 & 27 \\
\hline Hogere taalkundige, culturele beroepen & 88 & 88 & 38 & 38 \\
\hline Hogere beroepen mbt gedrag en maatschappij & 77 & 91 & 29 & 17 \\
\hline Hogere verzorgende beroepen & - & - & 20 & - \\
\hline Managers (HBO werk- en denkniveau) & 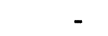 & - & - & \\
\hline Wetenschappelijke pedagogische beroepen & 91 & 94 & 37 & 66 \\
\hline Wetenschappelijke landbouwkundige beroepen & - & - & - & - \\
\hline Wetenschappelijke wiskundige, natuurw. beroepen & - & - & - & - \\
\hline Wetenschappelijke technische beroepen & - & - & - & - \\
\hline Wetenschappelijke (para)medische beroepen & - & - & - & - \\
\hline Wetenschappelijke economische, adm. beroepen & 59 & 79 & 21 & 14 \\
\hline Wetenschappelijke juridische, best. beroepen & 54 & 92 & 39 & 27 \\
\hline Wetenschappelijke beroepen mbt gedrag en maatschappij & 40 & - & 30 & 10 \\
\hline Managers (wetenschappelijk werk- en denkniveau) & & - & - & - \\
\hline
\end{tabular}

Bron: OSA/ROA 


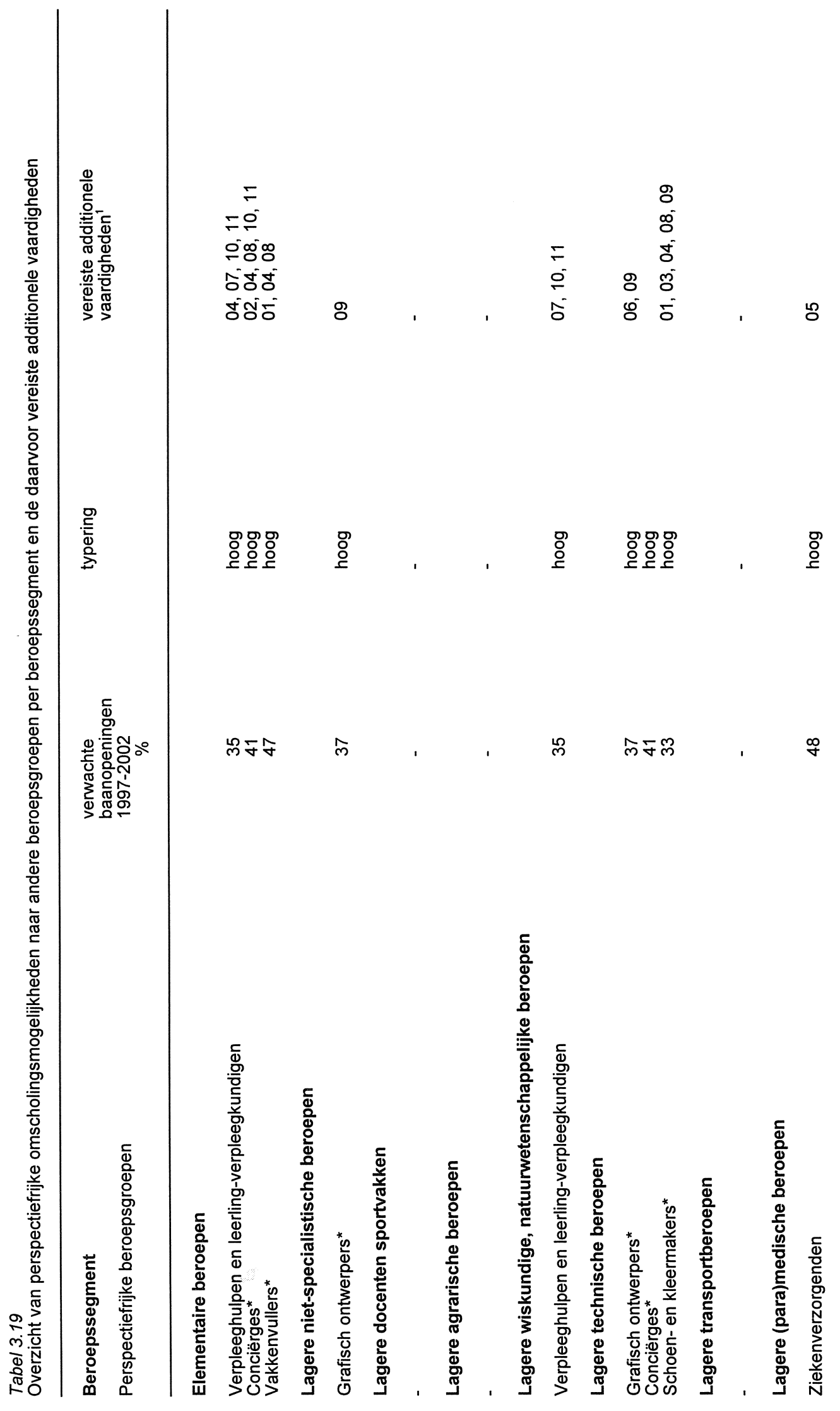




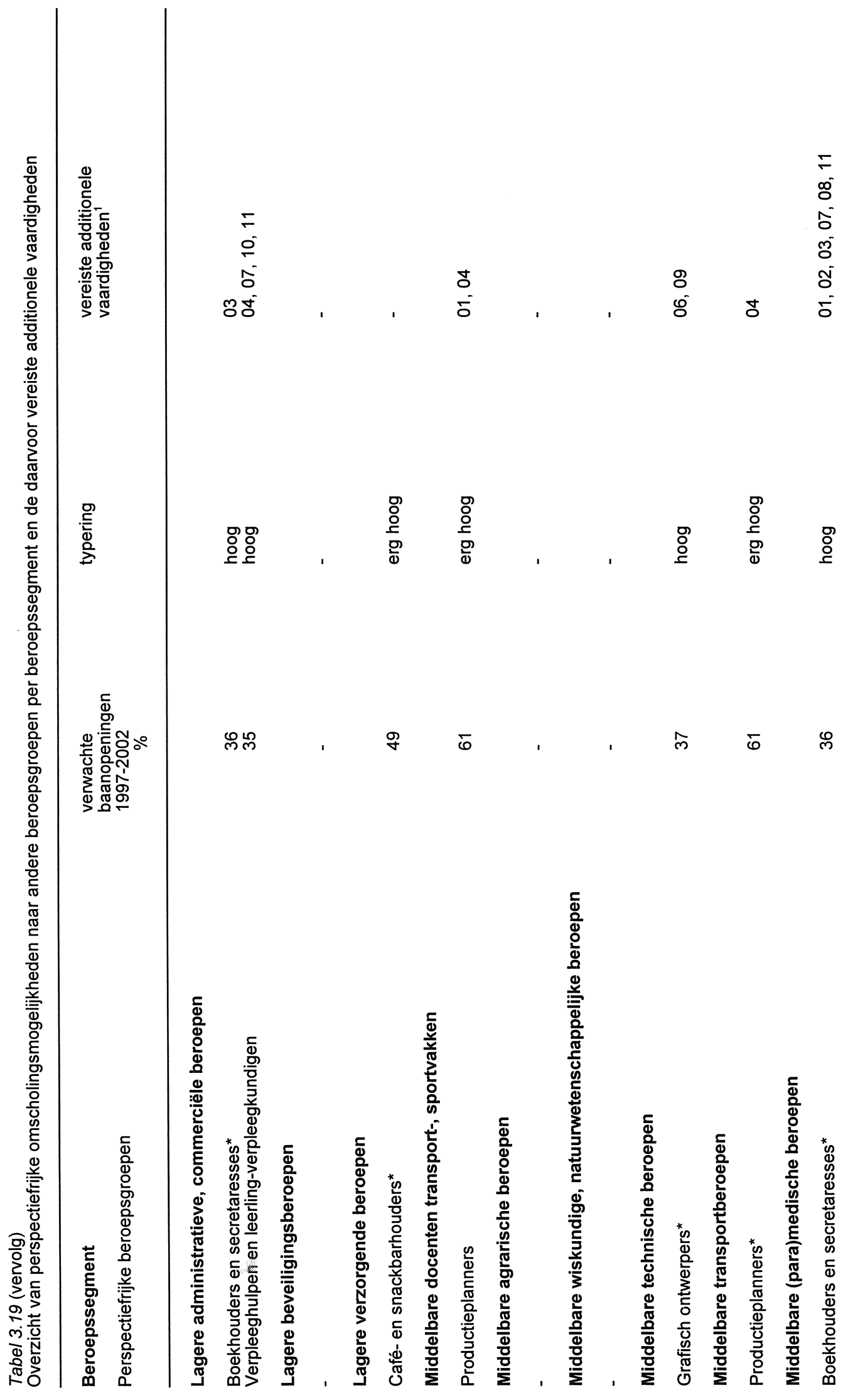




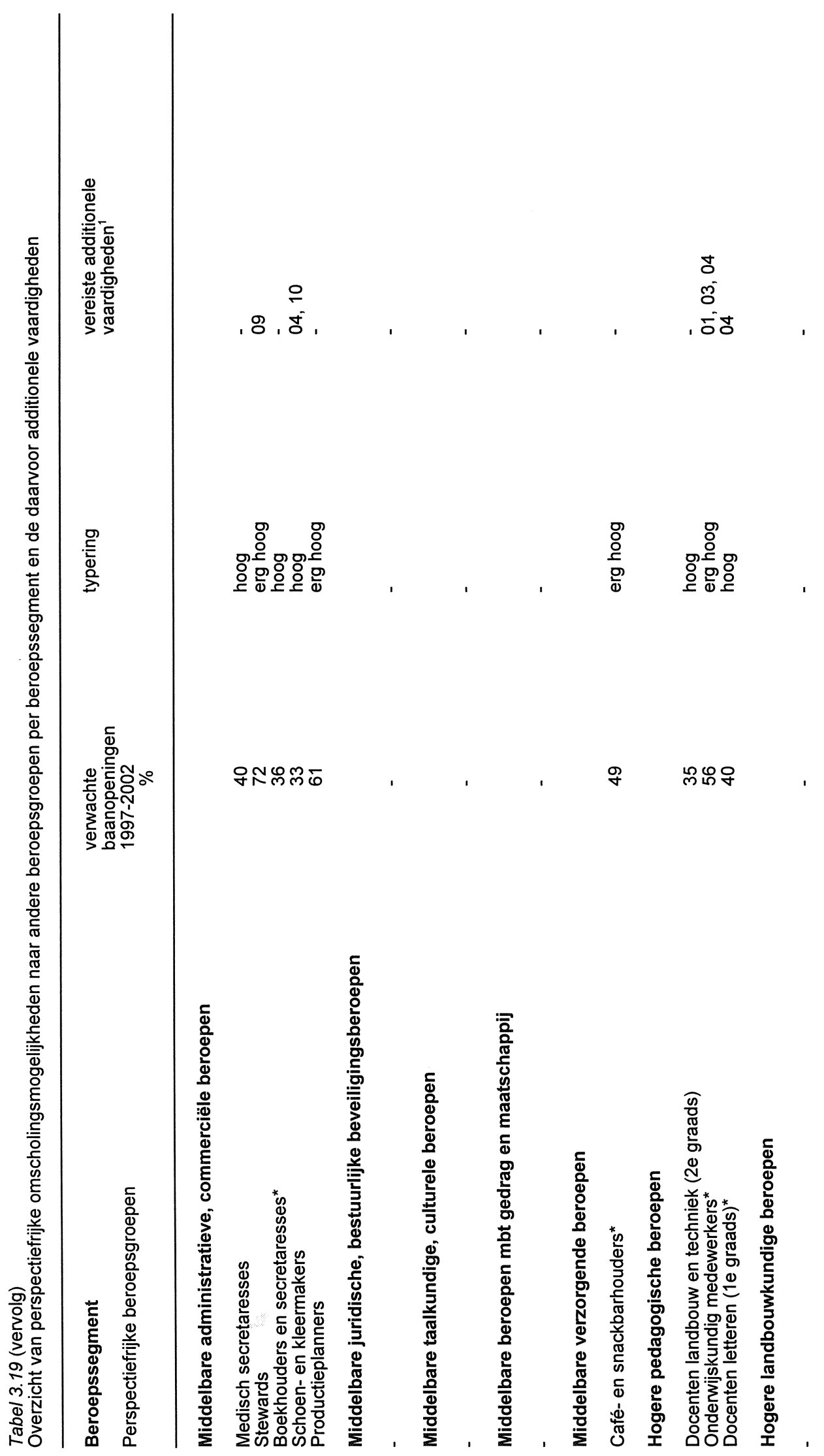




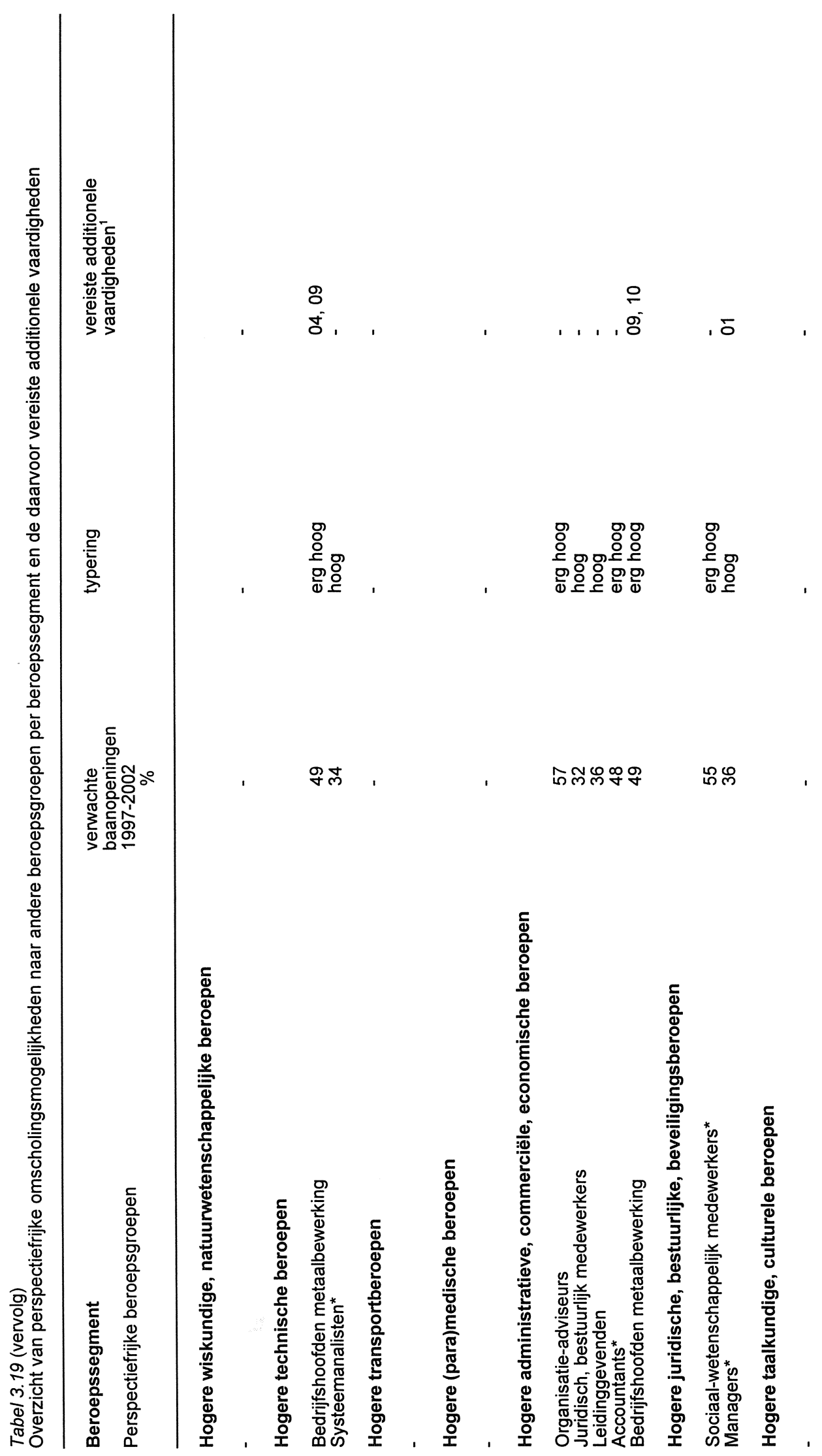




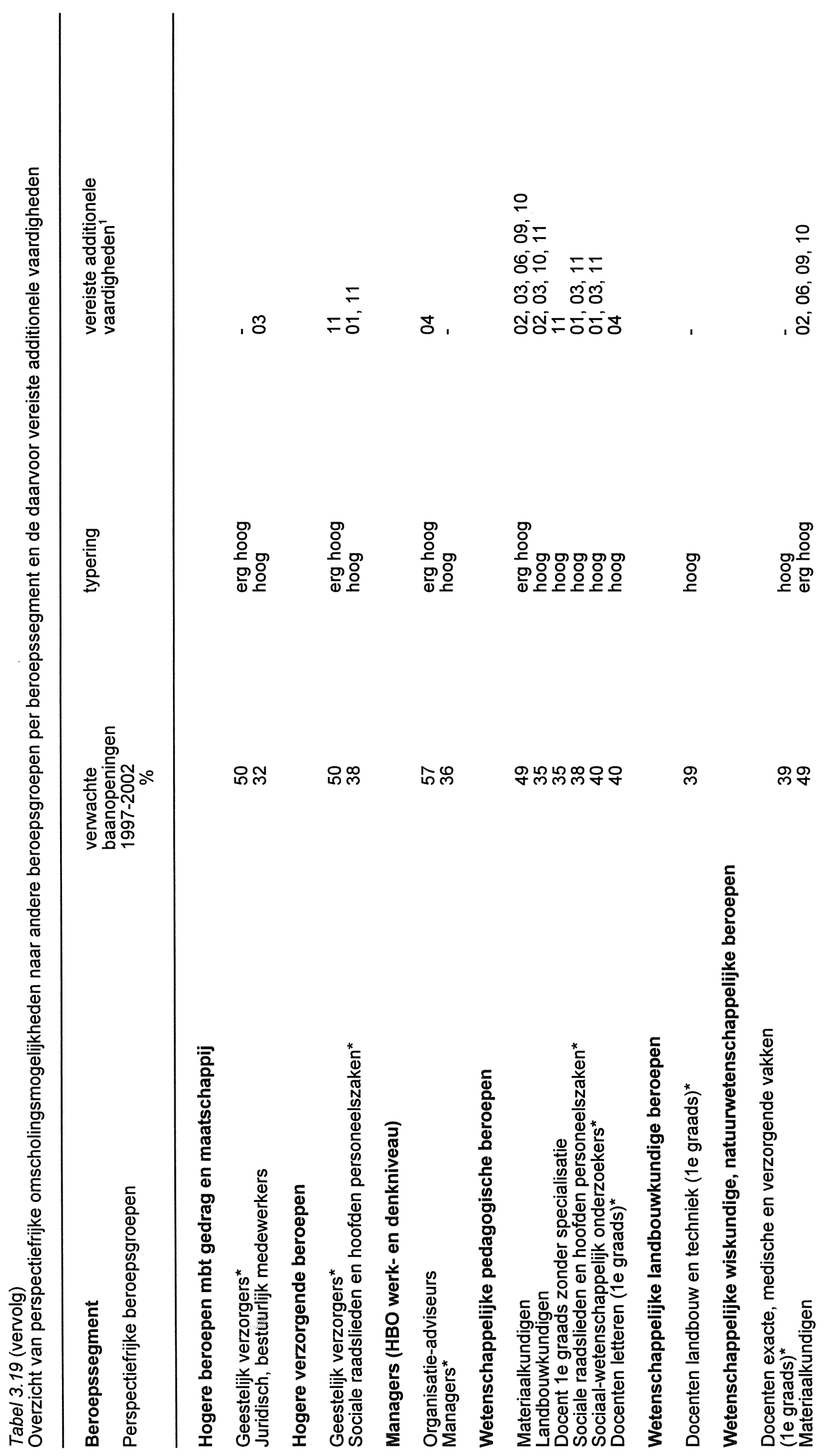




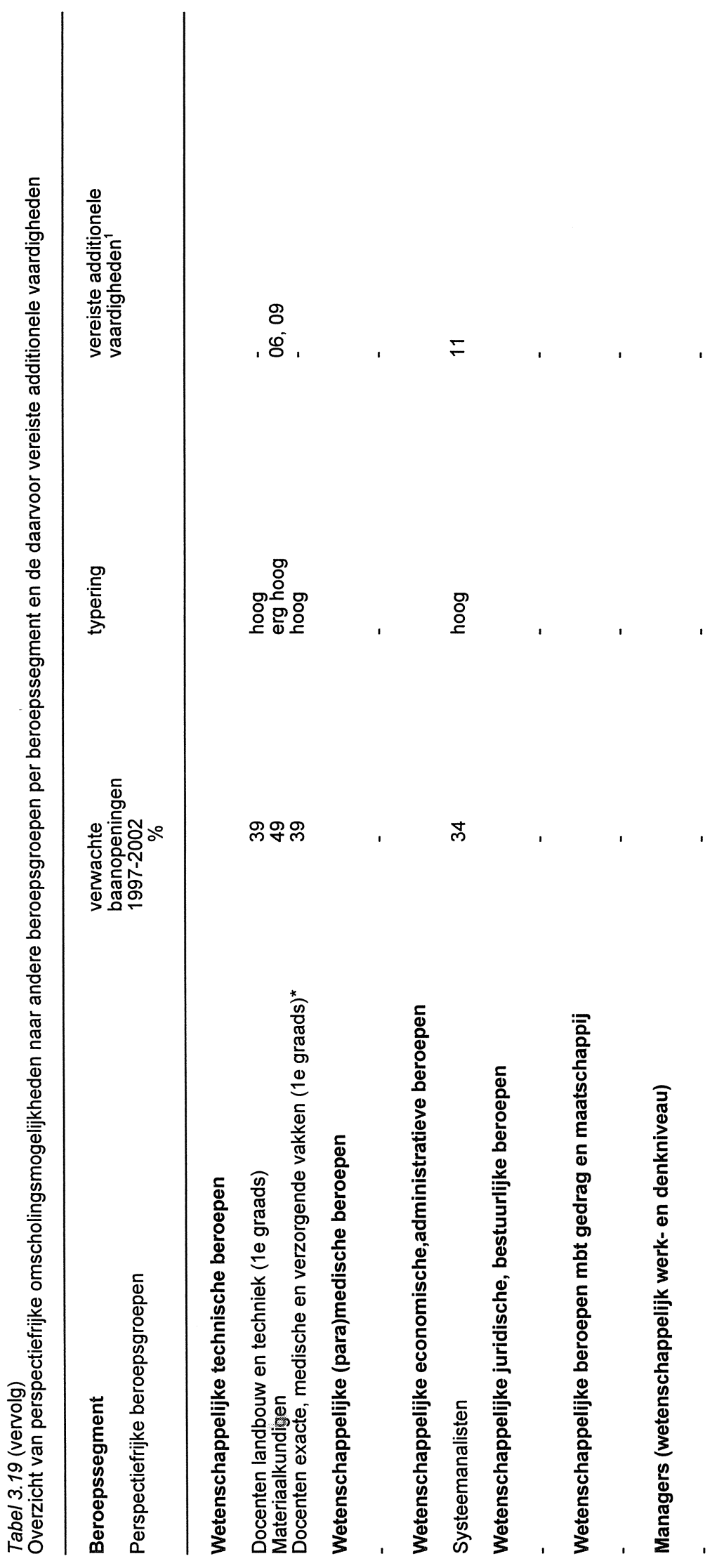




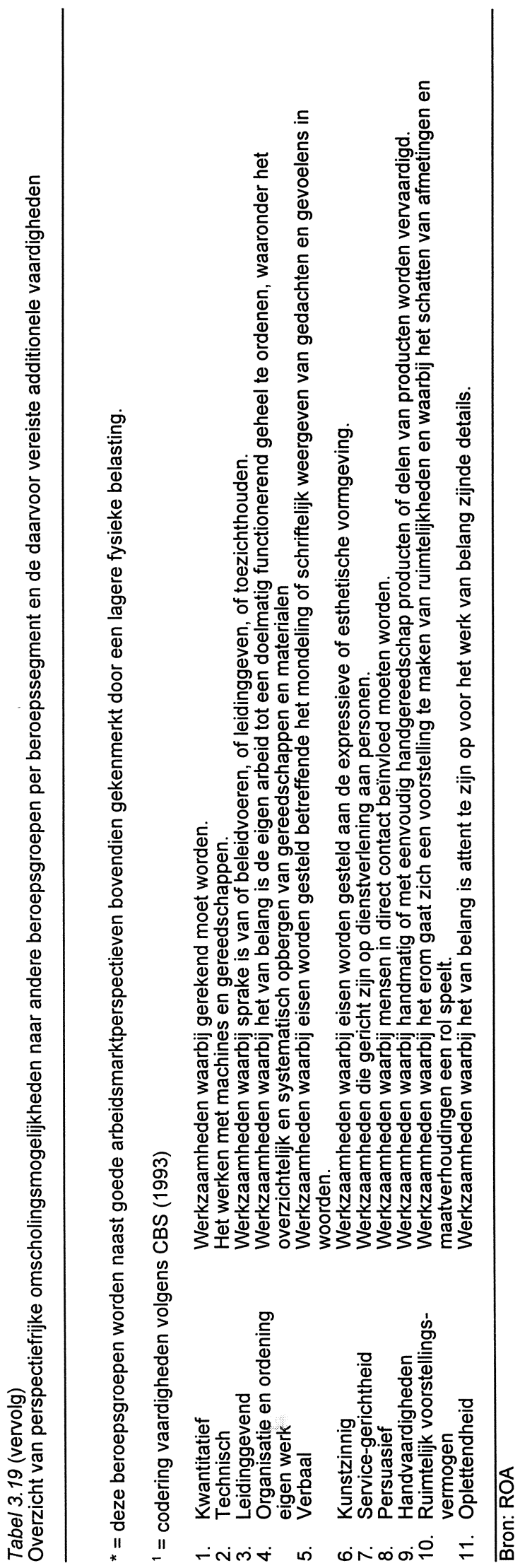


RISICOPROFIELEN NAAR BEROEP 


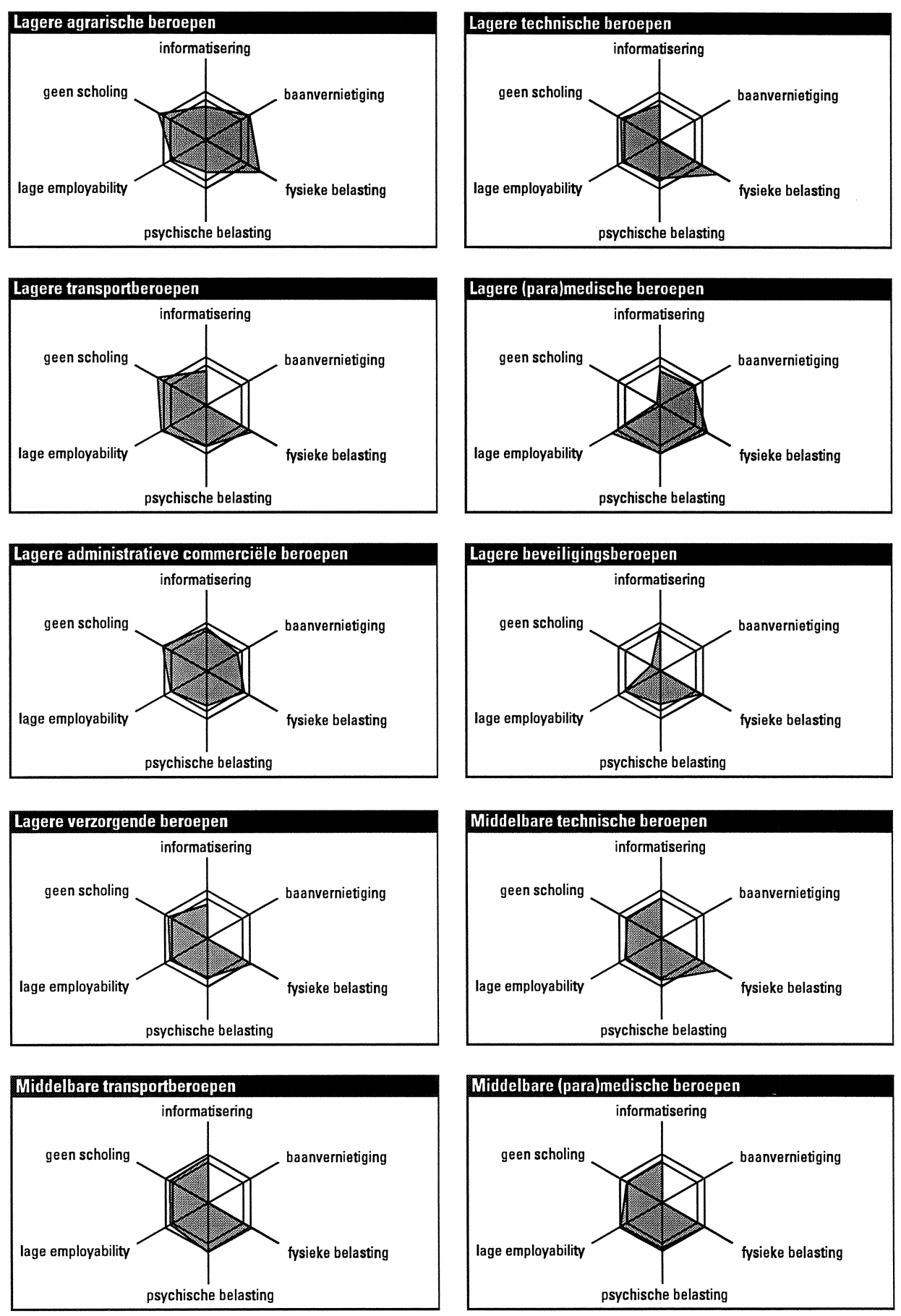

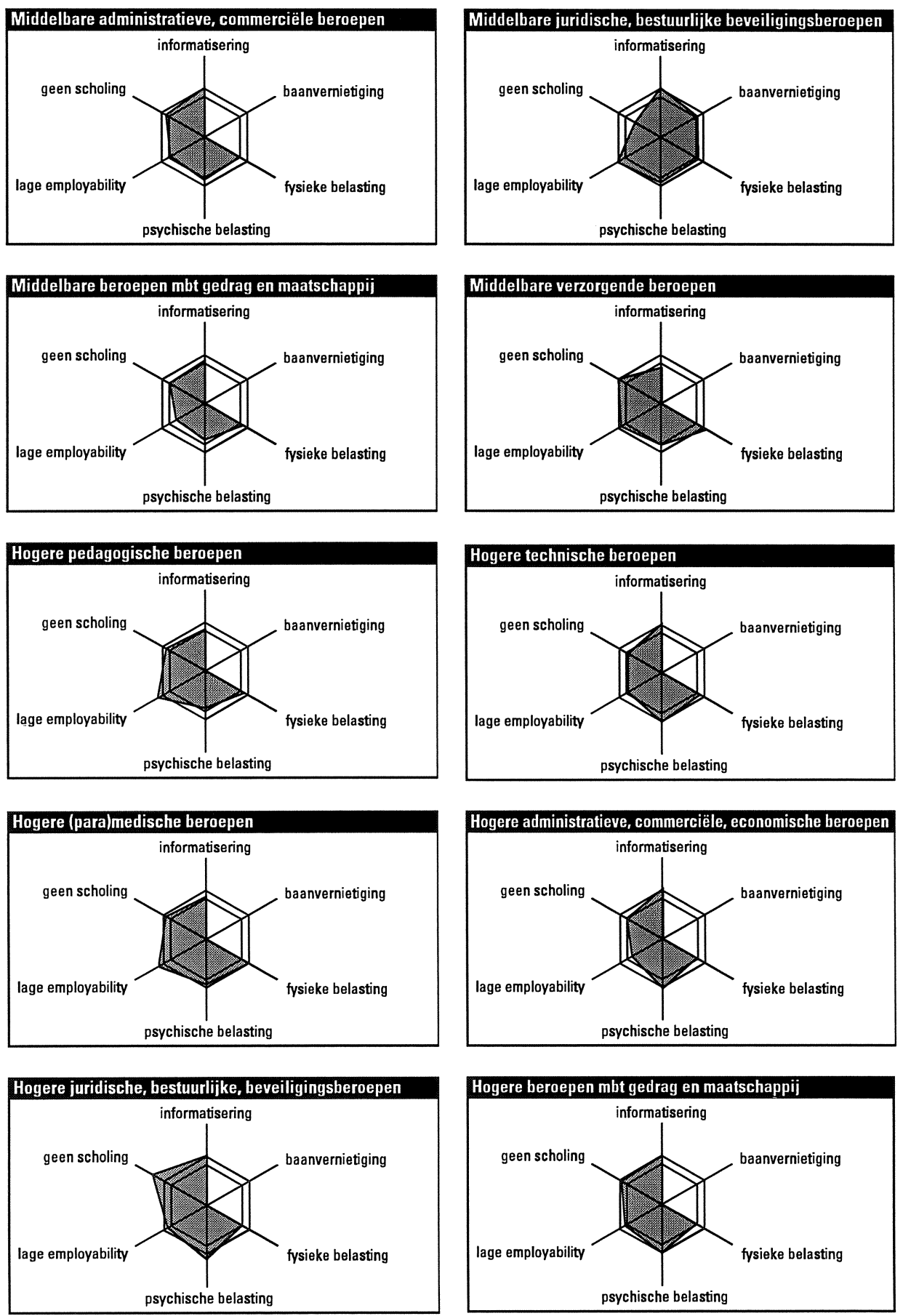

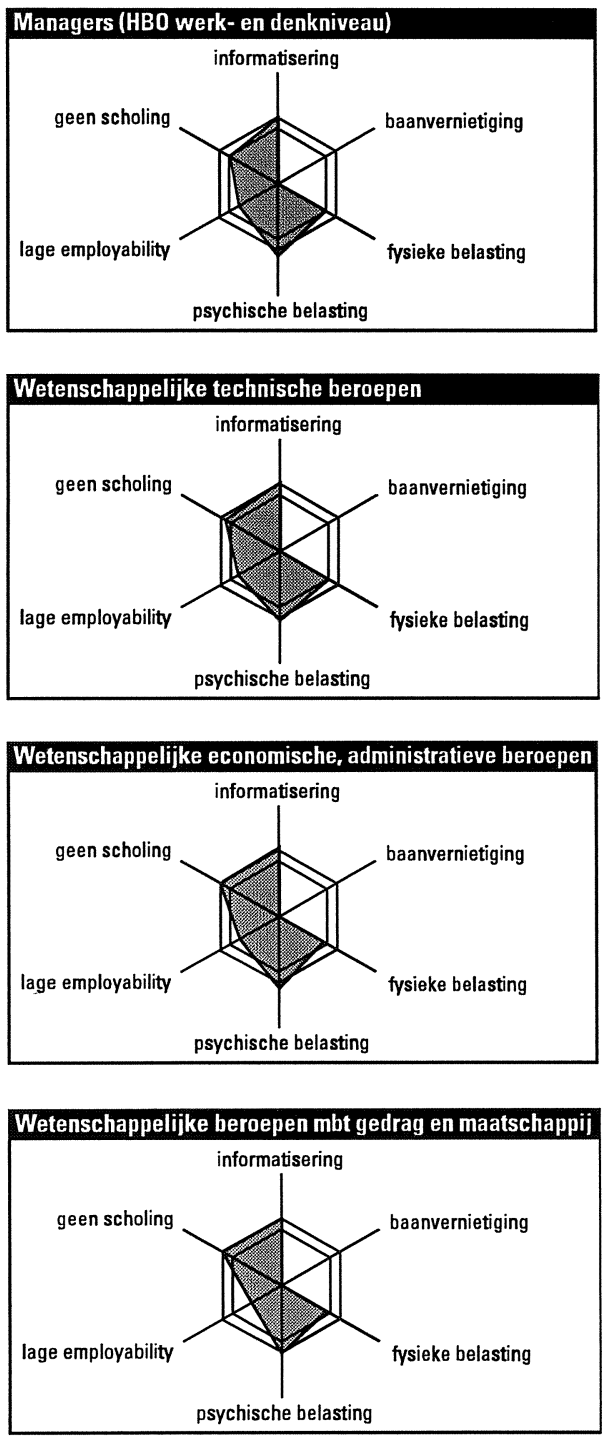
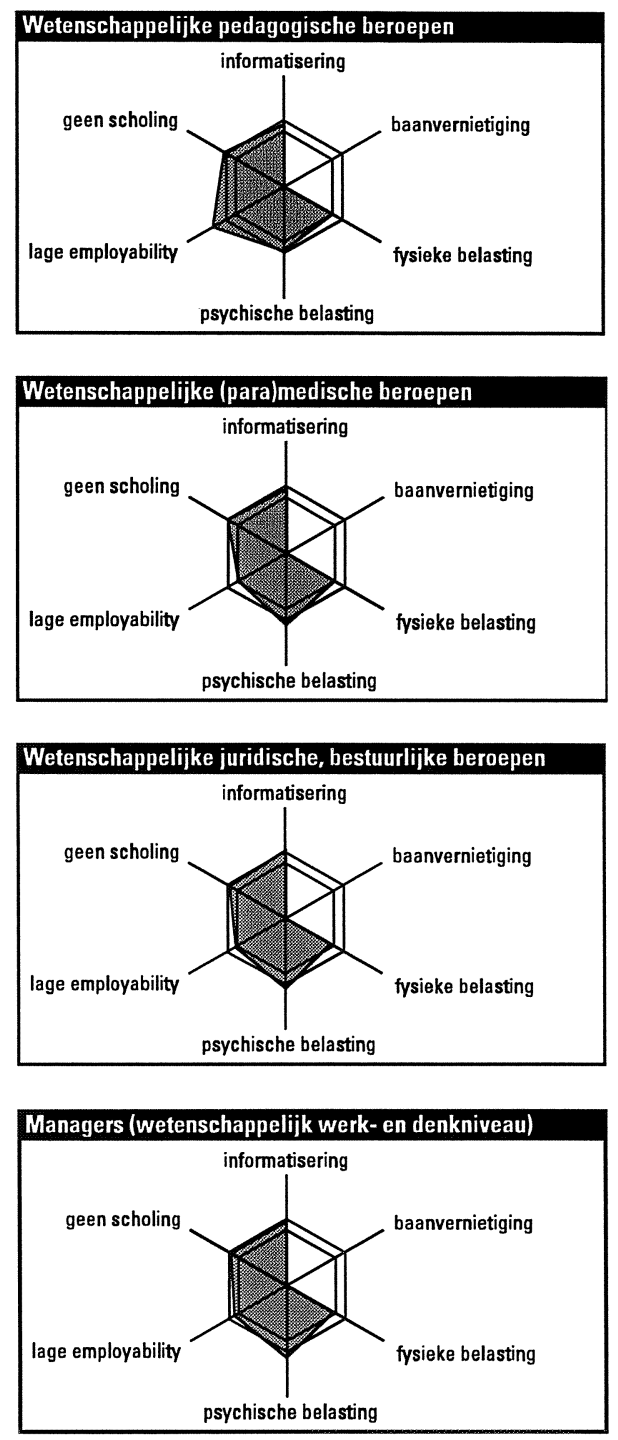

INFORMATIE OVER OPLEIDINGEN 

Tabel 4.1

Percentage werknemers dat geconfronteerd wordt met lawaai tijdens het werk, naar opleidingstype, 1996

\begin{tabular}{|c|c|c|}
\hline Opleidingstype & $\%$ & typering \\
\hline Basisonderwijs & 35 & hoog \\
\hline MAVO & 21 & gemiddeld \\
\hline VBO landbouw en natuurlijke omgeving & 40 & hoog \\
\hline VBO landbouw en natuurlijke omgeving & 40 & hoog \\
\hline VBO techniek & 45 & erg hoog \\
\hline $\begin{array}{l}\text { VBO bouwtechniek } \\
\text { VBO installatietechniek } \\
\text { VBO mechanische techniek } \\
\text { VBO fijnmechanische techniek } \\
\text { VBO motorvoertuigentechniek } \\
\text { VBO elektrotechniek } \\
\text { VBO grafische techniek } \\
\text { VBO brood en banket } \\
\text { VBO horeca en levensmiddelentechniek } \\
\text { VBO vervoer }\end{array}$ & $\begin{array}{r}46 \\
56 \\
- \\
45 \\
37 \\
- \\
- \\
32 \\
27\end{array}$ & $\begin{array}{l}\text { erg hoog } \\
\text { erg hoog } \\
\text { erg hoog } \\
\text { hoog } \\
\text { erg hoog } \\
\text { hoog } \\
\text { erg hoog } \\
\text { gemiddeld } \\
\text { hoog } \\
\text { gemiddeld }\end{array}$ \\
\hline VBO economie & 17 & gemiddeld \\
\hline VBO administratie, handel en textiel & 17 & gemiddeld \\
\hline VBO verzorging & 19 & gemiddeld \\
\hline VBO verzorging & 19 & gemiddeld \\
\hline VBO openbare orde en veiligheid & - & gemiddeld \\
\hline VBO beveiliging & - & gemiddeld \\
\hline HAVOIVWO & 15 & gemiddeld \\
\hline MBO/LLW landbouw en natuurlijke omgeving & 32 & hoog \\
\hline $\begin{array}{l}\text { MBO/LLW landbouw en veeteelt } \\
\text { MBO/LLW milieu en groene ruimte }\end{array}$ & $\begin{array}{l}30 \\
36\end{array}$ & $\begin{array}{l}\text { hoog } \\
\text { hoog }\end{array}$ \\
\hline MBO/LLW techniek & 42 & hoog \\
\hline $\begin{array}{l}\text { MBO/LLW laboratorium } \\
\text { MBO/LLW bouw } \\
\text { MBO/LLW grond-, weg- en waterbouw } \\
\text { MBO/LLW installatietechniek } \\
\text { MBO/LLW werktuigbouw en mechanische techniek } \\
\text { MBO/LLW fijnmechanische techniek } \\
\text { MBO/LLW motorvoertuigentechniek } \\
\text { MBO/LLW vliegtuigtechniek } \\
\text { MBO/LLW operationele techniek } \\
\text { MBO/LLW elektrotechniek } \\
\text { MBO/LLW grafische techniek } \\
\text { MBO/LLW procestechniek } \\
\text { MBO/LLW brood en banket } \\
\text { MBO/LLW levensmiddelentechniek/vleesverwerking } \\
\text { MBO/LLW vervoer }\end{array}$ & $\begin{array}{r}42 \\
40 \\
45 \\
52 \\
- \\
45 \\
- \\
- \\
36 \\
36 \\
65 \\
32 \\
30\end{array}$ & $\begin{array}{l}\text { gemiddeld } \\
\text { erg hoog } \\
\text { hoog } \\
\text { erg hoog } \\
\text { erg hoog } \\
\text { hoog } \\
\text { erg hoog } \\
\text { erg hoog } \\
\text { erg hoog } \\
\text { hoog } \\
\text { hoog } \\
\text { erg hoog } \\
\text { hoog } \\
\text { hoog } \\
\text { hoog }\end{array}$ \\
\hline MBO/LLW dienstverlening en gezondheidszorg & 17 & gemiddeld \\
\hline $\begin{array}{l}\text { MBO dokters-, tandarts- en dierenartsassistent } \\
\text { MBO/LLW apothekersassistent } \\
\text { MBO/LLW verpleging } \\
\text { MBO/LLW gezondheidstechniek } \\
\text { MBO sociaal-cultureel } \\
\text { MBO/LLW verzorging }\end{array}$ & $\begin{array}{r}- \\
13 \\
17 \\
17\end{array}$ & $\begin{array}{l}\text { gemiddeld } \\
\text { laag } \\
\text { gemiddeld } \\
\text { hoog } \\
\text { gemiddeld } \\
\text { gemiddeld }\end{array}$ \\
\hline
\end{tabular}


Tabel 4.1 (vervolg)

Percentage werknemers dat geconfronteerd wordt met lawaai tijdens het werk, naar opleidingstype, 1996

\begin{tabular}{|c|c|c|}
\hline Opleidingstype & $\%$ & typering \\
\hline $\begin{array}{l}\text { MBO/LLW uiterlijke verzorging } \\
\text { MBO/LLWW horeca } \\
\text { MBO/LLW beweging en therapie }\end{array}$ & $\begin{array}{r}13 \\
25 \\
-\end{array}$ & $\begin{array}{l}\text { gemiddeld } \\
\text { gemiddeld } \\
\text { gemiddeld }\end{array}$ \\
\hline MBO/LLW economie & 11 & gemiddeld \\
\hline $\begin{array}{l}\text { MBO/LLW administratie } \\
\text { MBO/LLW handel } \\
\text { MBO/LLW secretariaat } \\
\text { MBO/LLW toerisme en recreatie } \\
\text { MBO/LLW bedrijfskunde } \\
\text { MBO/LLW automatisering } \\
\text { MBO/LLW geld, bank en belastingen } \\
\text { MBO verzekeringswezen }\end{array}$ & $\begin{array}{r}9 \\
16 \\
9 \\
- \\
22 \\
- \\
- \\
-\end{array}$ & $\begin{array}{l}\text { laag } \\
\text { gemiddeld } \\
\text { laag } \\
\text { gemiddeld } \\
\text { gemiddeld } \\
\text { gemiddeld } \\
\text { laag } \\
\text { laag }\end{array}$ \\
\hline MBO openbare orde en veiligheid & 27 & gemiddeld \\
\hline MBO openbare orde en veiligheid & 27 & gemiddeld \\
\hline HBO onderwijs en tolk en vertaler & 26 & gemiddeld \\
\hline $\begin{array}{l}\text { HBO lerarenopleiding basisonderwijs } \\
\text { HBO lerarenopleiding talen } \\
\text { HBO lerarenopleiding natuur en techniek } \\
\text { HBO lerarenopleiding economie en maatschappij } \\
\text { HBO lerarenopleiding lichamelijke opvoeding } \\
\text { HBO lerarenopleiding medisch en verzorging } \\
\text { HBO lerarenopleiding expressie } \\
\text { HBO tolk en vertaler }\end{array}$ & $\begin{array}{r}29 \\
18 \\
24 \\
17 \\
39 \\
- \\
32 \\
-\end{array}$ & $\begin{array}{l}\text { gemiddeld } \\
\text { gemiddeld } \\
\text { gemiddeld } \\
\text { gemiddeld } \\
\text { hoog } \\
\text { gemiddeld } \\
\text { hoog } \\
\text { gemiddeld }\end{array}$ \\
\hline HBO landbouw & - & gemiddeld \\
\hline $\begin{array}{l}\text { HBO landbouw en veeteelt } \\
\text { HBO milieukunde en levensmiddelentechnologie }\end{array}$ & - & $\begin{array}{l}\text { gemiddeld } \\
\text { gemiddeld }\end{array}$ \\
\hline HBO techniek & 17 & gemiddeld \\
\hline $\begin{array}{l}\text { HBO laboratorium } \\
\text { HBO bouwkunde } \\
\text { HBO civiele techniek } \\
\text { HBO werktuigbouwkunde } \\
\text { HBO elektrotechniek } \\
\text { HBO informatica } \\
\text { HBO chemische technologie } \\
\text { HBO vervoer en logistiek }\end{array}$ & $\begin{array}{r}17 \\
- \\
16 \\
- \\
- \\
- \\
48\end{array}$ & $\begin{array}{l}\text { gemiddeld } \\
\text { gemiddeld } \\
\text { gemiddeld } \\
\text { gemiddeld } \\
\text { gemiddeld } \\
\text { laag } \\
\text { gemiddeld } \\
\text { erg hoog }\end{array}$ \\
\hline HBO paramedisch & 8 & laag \\
\hline $\begin{array}{l}\text { HBO verpleegkunde } \\
\text { HBO (fysio)therapie } \\
\text { HBO voeding } \\
\text { HBO radiologie }\end{array}$ & $\begin{array}{l}- \\
- \\
-\end{array}$ & $\begin{array}{l}\text { laag } \\
\text { laag } \\
\text { gemiddeld } \\
\text { laag }\end{array}$ \\
\hline HBO economie & 7 & laag \\
\hline $\begin{array}{l}\text { HBO accountancy en bedrijfseconomie } \\
\text { HBO commerciële economie } \\
\text { HBO toerisme en recreatie } \\
\text { HBO recht en bestuur } \\
\text { HBO secretariaat } \\
\text { HBO bedrijfskunde }\end{array}$ & $\begin{array}{l}- \\
- \\
- \\
-\end{array}$ & $\begin{array}{l}\text { laag } \\
\text { laag } \\
\text { gemiddeld } \\
\text { laag } \\
\text { laag } \\
\text { laag }\end{array}$ \\
\hline HBO sociaal-cultureel & 12 & gemiddeld \\
\hline $\begin{array}{l}\text { HBO communicatie en journalistiek } \\
\text { HBO maatschappelijk werk en hulpverlening }\end{array}$ & 14 & $\begin{array}{l}\text { gemiddeld } \\
\text { gemiddeld }\end{array}$ \\
\hline
\end{tabular}


Tabel 4.1 (vervolg)

Percentage werknemers dat geconfronteerd wordt met lawaai tijdens het werk, naar opleidingstype, 1996

\begin{tabular}{|c|c|c|}
\hline Opleidingstype & $\%$ & typering \\
\hline $\begin{array}{l}\text { HBO personeelswerk } \\
\text { HBO bibliotheek en documentatie }\end{array}$ & - & $\begin{array}{l}\text { laag } \\
\text { erg laag }\end{array}$ \\
\hline HBO kunst & - & gemiddeld \\
\hline HBO uitvoerende en beeldende kunsten & - & gemiddeld \\
\hline HBO openbare orde en veiligheid & - & gemiddeld \\
\hline HBO openbare orde en veiligheid & - & gemiddeld \\
\hline WO letteren en theologie & - & laag \\
\hline $\begin{array}{l}\text { WO letteren } \\
\text { WO theologie }\end{array}$ & - & $\begin{array}{l}\text { gemiddeld } \\
\text { erg laag }\end{array}$ \\
\hline WO landbouw en milieukunde & - & laag \\
\hline WO landbouw en milieukunde & - & laag \\
\hline WO techniek & 10 & gemiddeld \\
\hline $\begin{array}{l}\text { WO wiskunde en natuurwetenschappen } \\
\text { WO bouwkunde } \\
\text { WO civiele techniek } \\
\text { WO werktuigbouwkunde } \\
\text { WO elektrotechniek } \\
\text { WO informatica en bestuurlijke informatiekunde }\end{array}$ & $\begin{array}{r}14 \\
- \\
- \\
- \\
-\end{array}$ & $\begin{array}{l}\text { gemiddeld } \\
\text { erg laag } \\
\text { erg laag } \\
\text { laag } \\
\text { gemiddeld } \\
\text { erg laag }\end{array}$ \\
\hline WO medisch & - & laag \\
\hline $\begin{array}{l}\text { WO (dier)geneeskunde } \\
\text { WO tandheelkunde } \\
\text { WO farmacie }\end{array}$ & $\begin{array}{l}- \\
-\end{array}$ & $\begin{array}{l}\text { laag } \\
\text { hoog } \\
\text { erg laag }\end{array}$ \\
\hline WO economie & - & erg laag \\
\hline $\begin{array}{l}\text { WO econom(etr)ie } \\
\text { WO bedrijfskunde } \\
\text { WO accountancy en belastingen } \\
\text { WO rechten en bestuurskunde }\end{array}$ & $\begin{array}{l}- \\
- \\
-\end{array}$ & $\begin{array}{l}\text { erg laag } \\
\text { erg laag } \\
\text { erg laag } \\
\text { erg laag }\end{array}$ \\
\hline WO sociaal-cultureel & 6 & laag \\
\hline WO sociale wetenschappen & - & laag \\
\hline WO kunst & - & laag \\
\hline WO kunstwetenschappen & - & laag \\
\hline
\end{tabular}

Bron: CBS/ROA 
Tabel 4.2

Percentage werknemers dat gebruik maakt van gereedschap of apparaten die trilling veroorzaken, naar opleidingstype, 1996

\begin{tabular}{|c|c|c|}
\hline Opleidingstype & $\%$ & typering \\
\hline Basisonderwijs & 22 & hoog \\
\hline MAVO & 10 & gemiddeld \\
\hline VBO landbouw en natuurlijke omgeving & 37 & hoog \\
\hline VBO landbouw en natuurlijke omgeving & 37 & hoog \\
\hline VBO techniek & 39 & hoog \\
\hline $\begin{array}{l}\text { VBO bouwtechniek } \\
\text { VBO installatietechniek } \\
\text { VBO mechanische techniek } \\
\text { VBO fijnmechanische techniek } \\
\text { VBO motorvoertuigentechniek } \\
\text { VBO elektrotechniek } \\
\text { VBO grafische techniek } \\
\text { VBO brood en banket } \\
\text { VBO horeca en levensmiddelentechniek } \\
\text { VBO vervoer }\end{array}$ & $\begin{array}{r}49 \\
46 \\
- \\
40 \\
36 \\
- \\
- \\
23 \\
23\end{array}$ & $\begin{array}{l}\text { erg hoog } \\
\text { erg hoog } \\
\text { erg hoog } \\
\text { hoog } \\
\text { erg hoog } \\
\text { hoog } \\
\text { hoog } \\
\text { hoog } \\
\text { hoog } \\
\text { hoog }\end{array}$ \\
\hline VBO economie & 12 & gemiddeld \\
\hline VBO administratie, handel en textiel & 12 & gemiddeld \\
\hline VBO verzorging & 8 & gemiddeld \\
\hline VBO verzorging & 8 & gemiddeld \\
\hline VBO openbare orde en veiligheid & - & gemiddeld \\
\hline VBO beveiliging & - & gemiddeld \\
\hline HAVO/VWO & 6 & gemiddeld \\
\hline MBO/LLW landbouw en natuurlijke omgeving & 36 & hoog \\
\hline $\begin{array}{l}\text { MBO/LLW landbouw en veeteelt } \\
\text { MBO/LLW milieu en groene ruimte }\end{array}$ & $\begin{array}{l}29 \\
54\end{array}$ & $\begin{array}{l}\text { hoog } \\
\text { erg hoog }\end{array}$ \\
\hline MBO/LLW techniek & 35 & hoog \\
\hline $\begin{array}{l}\text { MBO/LLW laboratorium } \\
\text { MBO/LLW bouw } \\
\text { MBO/LLW grond-, weg-en waterbouw } \\
\text { MBO/LLW installatietechniek } \\
\text { MBO/LLW werktuigbouw en mechanische techniek } \\
\text { MBO/LLW fijnmechanische techniek } \\
\text { MBO/LLW motorvoertuigentechniek } \\
\text { MBO/LLW vliegtuigtechniek } \\
\text { MBO/LLW operationele techniek } \\
\text { MBO/LLW elektrotechniek } \\
\text { MBO/LLW grafische techniek } \\
\text { MBO/LLW procestechniek } \\
\text { MBO/LLW brood en banket } \\
\text { MBO/LLW levensmiddelentechniek/vleesverwerking } \\
\text { MBO/LLW vervoer }\end{array}$ & $\begin{array}{r}43 \\
32 \\
61 \\
43 \\
- \\
51 \\
- \\
- \\
30 \\
- \\
31 \\
- \\
- \\
-\end{array}$ & $\begin{array}{l}\text { gemiddeld } \\
\text { erg hoog } \\
\text { hoog } \\
\text { erg hoog } \\
\text { erg hoog } \\
\text { hoog } \\
\text { erg hoog } \\
\text { erg hoog } \\
\text { erg hoog } \\
\text { hoog } \\
\text { gemiddeld } \\
\text { hoog } \\
\text { hoog } \\
\text { gemiddeld } \\
\text { hoog }\end{array}$ \\
\hline MBO/LLW dienstverlening en gezondheidszorg & 5 & gemiddeld \\
\hline $\begin{array}{l}\text { MBO dokters-, tandarts- en dierenartsassistent } \\
\text { MBO/LLW apothekersassistent } \\
\text { MBO/LLW verpleging } \\
\text { MBO/LLW gezondheidstechniek }\end{array}$ & $\begin{array}{l}- \\
- \\
-\end{array}$ & $\begin{array}{l}\text { laag } \\
\text { gemiddeld } \\
\text { laag } \\
\text { hoog }\end{array}$ \\
\hline
\end{tabular}


Tabel 4.2 (vervolg)

Percentage werknemers dat gebruik maakt van gereedschap of apparaten die trilling veroorzaken, naar opleidingstype, 1996

\begin{tabular}{|c|c|c|}
\hline Opleidingstype & $\%$ & typering \\
\hline $\begin{array}{l}\text { MBO sociaal-cultureel } \\
\text { MBO/LLW verzorging } \\
\text { MBO/LLW uiterlijke verzorging } \\
\text { MBO/LLW horeca } \\
\text { MBO/LLW beweging en therapie }\end{array}$ & $\begin{array}{r}- \\
\overline{-} \\
11 \\
-\end{array}$ & $\begin{array}{l}\text { laag } \\
\text { laag } \\
\text { gemiddeld } \\
\text { gemiddeld } \\
\text { gemiddeld }\end{array}$ \\
\hline MBO/LLW economie & 4 & gemiddeld \\
\hline $\begin{array}{l}\text { MBO/LLW administratie } \\
\text { MBO/LLW handel } \\
\text { MBO/LLW secretariaat } \\
\text { MBO/LLW toerisme en recreatie } \\
\text { MBO/LLW bedrijfskunde } \\
\text { MBO/LLW automatisering } \\
\text { MBO/LLW geld, bank en belastingen } \\
\text { MBO verzekeringswezen }\end{array}$ & $\begin{array}{l}2 \\
9 \\
- \\
- \\
- \\
- \\
- \\
-\end{array}$ & $\begin{array}{l}\text { laag } \\
\text { gemiddeld } \\
\text { laag } \\
\text { laag } \\
\text { gemiddeld } \\
\text { gemiddeld } \\
\text { erg laag } \\
\text { erg laag }\end{array}$ \\
\hline MBO openbare orde en veiligheid & 16 & gemiddeld \\
\hline MBO openbare orde en veiligheid & 16 & gemiddeld \\
\hline HBO onderwijs en tolk en vertaler & 3 & laag \\
\hline $\begin{array}{l}\text { HBO lerarenopleiding basisonderwijs } \\
\text { HBO lerarenopleiding talen } \\
\text { HBO lerarenopleiding natuur en techniek } \\
\text { HBO lerarenopleiding economie en maatschappij } \\
\text { HBO lerarenopleiding lichamelijke opvoeding } \\
\text { HBO lerarenopleiding medisch en verzorging } \\
\text { HBO lerarenopleiding expressie } \\
\text { HBO tolk en vertaler }\end{array}$ & $\begin{array}{l}- \\
- \\
- \\
- \\
- \\
-\end{array}$ & $\begin{array}{l}\text { laag } \\
\text { laag } \\
\text { gemiddeld } \\
\text { laag } \\
\text { laag } \\
\text { laag } \\
\text { gemiddeld } \\
\text { gemiddeld }\end{array}$ \\
\hline HBO landbouw & - & gemiddeld \\
\hline $\begin{array}{l}\text { HBO landbouw en veeteelt } \\
\text { HBO milieukunde en levensmiddelentechnologie }\end{array}$ & - & $\begin{array}{l}\text { gemiddeld } \\
\text { gemiddeld }\end{array}$ \\
\hline HBO techniek & 7 & gemiddeld \\
\hline $\begin{array}{l}\text { HBO laboratorium } \\
\text { HBO bouwkunde } \\
\text { HBO civiele techniek } \\
\text { HBO werktuigbouwkunde } \\
\text { HBO elektrotechniek } \\
\text { HBO informatica } \\
\text { HBO chemische technologie } \\
\text { HBO vervoer en logistiek }\end{array}$ & $\begin{array}{l}- \\
- \\
- \\
- \\
-\end{array}$ & $\begin{array}{l}\text { gemiddeld } \\
\text { gemiddeld } \\
\text { gemiddeld } \\
\text { gemiddeld } \\
\text { gemiddeld } \\
\text { laag } \\
\text { gemiddeld } \\
\text { hoog }\end{array}$ \\
\hline HBO paramedisch & 6 & gemiddeld \\
\hline $\begin{array}{l}\text { HBO verpleegkunde } \\
\text { HBO (fysio)therapie } \\
\text { HBO voeding } \\
\text { HBO radiologie }\end{array}$ & $\begin{array}{l}- \\
- \\
-\end{array}$ & $\begin{array}{l}\text { gemiddeld } \\
\text { gemiddeld } \\
\text { gemiddeld } \\
\text { gemiddeld }\end{array}$ \\
\hline HBO economie & - & laag \\
\hline $\begin{array}{l}\text { HBO accountancy en bedrijfseconomie } \\
\text { HBO commerciële economie } \\
\text { HBO toerisme en recreatie } \\
\text { HBO recht en bestuur } \\
\text { HBO secretariaat } \\
\text { HBO bedrijfskunde }\end{array}$ & $\begin{array}{l}- \\
- \\
- \\
-\end{array}$ & $\begin{array}{l}\text { laag } \\
\text { erg laag } \\
\text { laag } \\
\text { laag } \\
\text { erg laag } \\
\text { erg laag }\end{array}$ \\
\hline
\end{tabular}


Tabel 4.2 (vervolg)

Percentage werknemers dat gebruik maakt van gereedschap of apparaten die trilling veroorzaken, naar opleidingstype, 1996

\begin{tabular}{|c|c|c|}
\hline Opleidingstype & $\%$ & typering \\
\hline HBO sociaal-cultureel & - & laag \\
\hline $\begin{array}{l}\text { HBO communicatie en journalistiek } \\
\text { HBO maatschappelijk werk en hulpverlening } \\
\text { HBO personeelswerk } \\
\text { HBO bibliotheek en documentatie }\end{array}$ & $\begin{array}{l}- \\
- \\
-\end{array}$ & $\begin{array}{l}\text { erg laag } \\
\text { laag } \\
\text { erg laag } \\
\text { erg laag }\end{array}$ \\
\hline HBO kunst & - & gemiddeld \\
\hline HBO uitvoerende en beeldende kunsten & - & gemiddeld \\
\hline HBO openbare orde en veiligheid & - & gemiddeld \\
\hline HBO openbare orde en veiligheid & - & gemiddeld \\
\hline WO letteren en theologie & - & erg laag \\
\hline $\begin{array}{l}\text { WO letteren } \\
\text { WO theologie }\end{array}$ & - & $\begin{array}{l}\text { erg laag } \\
\text { erg laag }\end{array}$ \\
\hline WO landbouw en milieukunde & - & erg laag \\
\hline WO landbouw en milieukunde & - & erg laag \\
\hline WO techniek & - & gemiddeld \\
\hline $\begin{array}{l}\text { WO wiskunde en natuurwetenschappen } \\
\text { WO bouwkunde } \\
\text { WO civiele techniek } \\
\text { WO werktuigbouwkunde } \\
\text { WO elektrotechniek } \\
\text { WO informatica en bestuurlijke informatiekunde }\end{array}$ & $\begin{array}{l}- \\
- \\
- \\
-\end{array}$ & $\begin{array}{l}\text { gemiddeld } \\
\text { erg laag } \\
\text { erg laag } \\
\text { gemiddeld } \\
\text { gemiddeld } \\
\text { erg laag }\end{array}$ \\
\hline WO medisch & - & gemiddeld \\
\hline $\begin{array}{l}\text { WO (dier)geneeskunde } \\
\text { WO tandheelkunde } \\
\text { WO farmacie }\end{array}$ & $\begin{array}{l}- \\
-\end{array}$ & $\begin{array}{l}\text { gemiddeld } \\
\text { gemiddeld } \\
\text { gemiddeld }\end{array}$ \\
\hline WO economie & - & erg laag \\
\hline $\begin{array}{l}\text { WO econom(etr)ie } \\
\text { WO bedrijfskunde } \\
\text { WO accountancy en belastingen } \\
\text { WO rechten en bestuurskunde }\end{array}$ & $\begin{array}{l}- \\
- \\
-\end{array}$ & $\begin{array}{l}\text { erg laag } \\
\text { erg laag } \\
\text { erg laag } \\
\text { erg laag }\end{array}$ \\
\hline WO sociaal-cultureel & - & erg laag \\
\hline WO sociale wetenschappen & - & laag \\
\hline WO kunst & - & laag \\
\hline WO kunstwetenschappen & - & laag \\
\hline
\end{tabular}

Bron: CBS/ROA 
Tabel 4.3

Percentage werknemers dat kracht moet zetten tijdens het werk, naar opleidingstype, 1996

\begin{tabular}{|c|c|c|}
\hline Opleidingstype & $\%$ & typering \\
\hline Basisonderwijs & 58 & hoog \\
\hline MAVO & 35 & gemiddeld \\
\hline VBO landbouw en natuurlijke omgeving & 66 & erg hoog \\
\hline VBO landbouw en natuurlijke omgeving & 66 & erg hoog \\
\hline VBO techniek & 67 & erg hoog \\
\hline $\begin{array}{l}\text { VBO bouwtechniek } \\
\text { VBO installatietechniek } \\
\text { VBO mechanische techniek } \\
\text { VBO fijnmechanische techniek } \\
\text { VBO motorvoertuigentechniek } \\
\text { VBO elektrotechniek } \\
\text { VBO grafische techniek } \\
\text { VBO brood en banket } \\
\text { VBO horeca en levensmiddelentechniek } \\
\text { VBO vervoer }\end{array}$ & $\begin{array}{l}73 \\
81 \\
68 \\
- \\
67 \\
59 \\
- \\
59 \\
60 \\
65\end{array}$ & $\begin{array}{l}\text { erg hoog } \\
\text { erg hoog } \\
\text { erg hoog } \\
\text { gemiddeld } \\
\text { erg hoog } \\
\text { hoog } \\
\text { gemiddeld } \\
\text { hoog } \\
\text { hoog } \\
\text { erg hoog }\end{array}$ \\
\hline VBO economie & 40 & gemiddeld \\
\hline VBO administratie, handel en textiel & 40 & gemiddeld \\
\hline VBO verzorging & 47 & hoog \\
\hline VBO verzorging & 47 & hoog \\
\hline VBO openbare orde en veiligheid & - & gemiddeld \\
\hline VBO beveiliging & - & gemiddeld \\
\hline HAVOIVWO & 23 & gemiddeld \\
\hline MBO/LLW landbouw en natuurlijke omgeving & 63 & hoog \\
\hline $\begin{array}{l}\text { MBO/LLW landbouw en veeteelt } \\
\text { MBO/LLW milieu en groene ruimte }\end{array}$ & $\begin{array}{l}60 \\
70\end{array}$ & $\begin{array}{l}\text { hoog } \\
\text { erg hoog }\end{array}$ \\
\hline MBO/LLW techniek & 50 & hoog \\
\hline $\begin{array}{l}\text { MBO/LLW laboratorium } \\
\text { MBO/LLWW bouw } \\
\text { MBO/LLW grond-, weg- en waterbouw } \\
\text { MBO/LLW installatietechniek } \\
\text { MBO/LLWW werktuigbouw en mechanische techniek } \\
\text { MBO/LLWW fijnmechanische techniek } \\
\text { MBO/LLWW motorvoertuigentechniek } \\
\text { MBO/LLW vliegtuigtechniek } \\
\text { MBO/LLW operationele techniek } \\
\text { MBO/LLW elektrotechniek } \\
\text { MBO/LLW grafische techniek } \\
\text { MBO/LLW procestechniek } \\
\text { MBO/LLW brood en banket } \\
\text { MBO/LLW levensmiddelentechniek/vleesverwerking } \\
\text { MBO/LLWW vervoer }\end{array}$ & $\begin{array}{r}58 \\
40 \\
74 \\
53 \\
69 \\
- \\
- \\
42 \\
26 \\
48 \\
75 \\
60 \\
38\end{array}$ & $\begin{array}{l}\text { gemiddeld } \\
\text { hoog } \\
\text { gemiddeld } \\
\text { erg hoog } \\
\text { hoog } \\
\text { gemiddeld } \\
\text { erg hoog } \\
\text { hoog } \\
\text { hoog } \\
\text { gemiddeld } \\
\text { gemiddeld } \\
\text { hoog } \\
\text { erg hoog } \\
\text { hoog } \\
\text { gemiddeld }\end{array}$ \\
\hline MBO/LLW dienstverlening en gezondheidszorg & 53 & hoog \\
\hline $\begin{array}{l}\text { MBO dokters-, tandarts- en dierenartsassistent } \\
\text { MBO/LLW apothekersassistent } \\
\text { MBO/LLWW verpleging } \\
\text { MBO/LLW gezondheidstechniek } \\
\text { MBO sociaal-cultureel }\end{array}$ & $\begin{array}{r}- \\
68 \\
3 \overline{5}\end{array}$ & $\begin{array}{l}\text { gemiddeld } \\
\text { gemiddeld } \\
\text { erg hoog } \\
\text { gemiddeld } \\
\text { gemiddeld }\end{array}$ \\
\hline
\end{tabular}


Tabel 4.3 (vervolg)

Percentage werknemers dat kracht moet zetten tijdens het werk, naar opleidingstype, 1996

\begin{tabular}{|c|c|c|}
\hline Opleidingstype & $\%$ & typering \\
\hline $\begin{array}{l}\text { MBO/LLW verzorging } \\
\text { MBO/LLW uiterlijke verzorging } \\
\text { MBO/LLW horeca } \\
\text { MBO/LLW beweging en therapie }\end{array}$ & $\begin{array}{l}66 \\
24 \\
46 \\
51\end{array}$ & $\begin{array}{l}\text { erg hoog } \\
\text { gemiddeld } \\
\text { gemiddeld } \\
\text { hoog }\end{array}$ \\
\hline MBO/LLW economie & 19 & gemiddeld \\
\hline $\begin{array}{l}\text { MBO/LLW administratie } \\
\text { MBO/LLW handel } \\
\text { MBO/LLW secretariaat } \\
\text { MBO/LLW toerisme en recreatie } \\
\text { MBO/LLW bedrijfskunde } \\
\text { MBO/LLW automatisering } \\
\text { MBO/LLW geld, bank en belastingen } \\
\text { MBO verzekeringswezen }\end{array}$ & $\begin{array}{r}13 \\
37 \\
9 \\
- \\
15 \\
14 \\
- \\
-\end{array}$ & $\begin{array}{l}\text { gemiddeld } \\
\text { gemiddeld } \\
\text { laag } \\
\text { laag } \\
\text { gemiddeld } \\
\text { gemiddeld } \\
\text { laag } \\
\text { laag }\end{array}$ \\
\hline MBO openbare orde en veiligheid & 34 & gemiddeld \\
\hline MBO openbare orde en veiligheid & 34 & gemiddeld \\
\hline HBO onderwijs en tolk en vertaler & 13 & gemiddeld \\
\hline $\begin{array}{l}\text { HBO lerarenopleiding basisonderwijs } \\
\text { HBO lerarenopleiding talen } \\
\text { HBO lerarenopleiding natuur en techniek } \\
\text { HBO lerarenopleiding economie en maatschappij } \\
\text { HBO lerarenopleiding lichamelijke opvoeding } \\
\text { HBO lerarenopleiding medisch en verzorging } \\
\text { HBO lerarenopleiding expressie } \\
\text { HBO tolk en vertaler }\end{array}$ & $\begin{array}{r}12 \\
- \\
- \\
46 \\
- \\
22 \\
-\end{array}$ & $\begin{array}{l}\text { gemiddeld } \\
\text { laag } \\
\text { laag } \\
\text { laag } \\
\text { hoog } \\
\text { gemiddeld } \\
\text { gemiddeld } \\
\text { gemiddeld }\end{array}$ \\
\hline HBO landbouw & - & gemiddeld \\
\hline $\begin{array}{l}\text { HBO landbouw en veeteelt } \\
\text { HBO milieukunde en levensmiddelentechnologie }\end{array}$ & - & $\begin{array}{l}\text { gemiddeld } \\
\text { gemiddeld }\end{array}$ \\
\hline HBO techniek & 9 & gemiddeld \\
\hline $\begin{array}{l}\text { HBO laboratorium } \\
\text { HBO bouwkunde } \\
\text { HBO civiele techniek } \\
\text { HBO werktuigbouwkunde } \\
\text { HBO elektrotechniek } \\
\text { HBO informatica } \\
\text { HBO chemische technologie } \\
\text { HBO vervoer en logistiek }\end{array}$ & $\begin{array}{l}- \\
- \\
- \\
- \\
- \\
-\end{array}$ & $\begin{array}{l}\text { gemiddeld } \\
\text { erg laag } \\
\text { gemiddeld } \\
\text { laag } \\
\text { laag } \\
\text { laag } \\
\text { gemiddeld } \\
\text { gemiddeld }\end{array}$ \\
\hline HBO paramedisch & 46 & hoog \\
\hline $\begin{array}{l}\text { HBO verpleegkunde } \\
\text { HBO (fysio)therapie } \\
\text { HBO voeding } \\
\text { HBO radiologie }\end{array}$ & $\begin{array}{r}48 \\
53 \\
- \\
-\end{array}$ & $\begin{array}{l}\text { hoog } \\
\text { hoog } \\
\text { gemiddeld } \\
\text { hoog }\end{array}$ \\
\hline HBO economie & 6 & laag \\
\hline $\begin{array}{l}\text { HBO accountancy en bedrijfseconomie } \\
\text { HBO commerciële economie } \\
\text { HBO toerisme en recreatie } \\
\text { HBO recht en bestuur } \\
\text { HBO secretariaat } \\
\text { HBO bedrifskunde }\end{array}$ & $\begin{array}{l}- \\
- \\
- \\
-\end{array}$ & $\begin{array}{l}\text { erg laag } \\
\text { laag } \\
\text { gemiddeld } \\
\text { laag } \\
\text { laag } \\
\text { laag }\end{array}$ \\
\hline
\end{tabular}


Tabel 4.3 (vervolg)

Percentage werknemers dat kracht moet zetten tijdens het werk, naar opleidingstype, 1996

\begin{tabular}{|c|c|c|}
\hline Opleidingstype & $\%$ & typering \\
\hline HBO sociaal-cultureel & 14 & gemiddeld \\
\hline $\begin{array}{l}\text { HBO communicatie en journalistiek } \\
\text { HBO maatschappelijk werk en hulpverlening } \\
\text { HBO personeelswerk } \\
\text { HBO bibliotheek en documentatie }\end{array}$ & $1 \overline{-}$ & $\begin{array}{l}\text { laag } \\
\text { gemiddeld } \\
\text { erg laag } \\
\text { gemiddeld }\end{array}$ \\
\hline HBO kunst & - & gemiddeld \\
\hline HBO uitvoerende en beeldende kunsten & - & gemiddeld \\
\hline HBO openbare orde en veiligheid & - & gemiddeld \\
\hline HBO openbare orde en veiligheid & - & gemiddeld \\
\hline WO letteren en theologie & - & laag \\
\hline $\begin{array}{l}\text { WO letteren } \\
\text { WO theologie }\end{array}$ & - & $\begin{array}{l}\text { laag } \\
\text { erg laag }\end{array}$ \\
\hline WO landbouw en milieukunde & - & gemiddeld \\
\hline WO landbouw en milieukunde & - & gemiddeld \\
\hline WO techniek & - & laag \\
\hline $\begin{array}{l}\text { WO wiskunde en natuurwetenschappen } \\
\text { WO bouwkunde } \\
\text { WO civiele techniek } \\
\text { WO werktuigbouwkunde } \\
\text { WO elektrotechniek } \\
\text { WO informatica en bestuurlijke informatiekunde }\end{array}$ & $\begin{array}{l}- \\
- \\
- \\
-\end{array}$ & $\begin{array}{l}\text { laag } \\
\text { erg laag } \\
\text { erg laag } \\
\text { erg laag } \\
\text { laag } \\
\text { erg laag }\end{array}$ \\
\hline WO medisch & - & gemiddeld \\
\hline $\begin{array}{l}\text { WO (dier)geneeskunde } \\
\text { WO tandheelkunde } \\
\text { WO farmacie }\end{array}$ & $\begin{array}{l}- \\
-\end{array}$ & $\begin{array}{l}\text { gemiddeld } \\
\text { erg laag } \\
\text { erg laag }\end{array}$ \\
\hline WO economie & - & erg laag \\
\hline $\begin{array}{l}\text { WO econom(etr)ie } \\
\text { WO bedrijfskunde } \\
\text { WO accountancy en belastingen } \\
\text { WO rechten en bestuurskunde }\end{array}$ & $\begin{array}{l}- \\
- \\
-\end{array}$ & $\begin{array}{l}\text { erg laag } \\
\text { erg laag } \\
\text { laag } \\
\text { laag }\end{array}$ \\
\hline WO sociaal-cultureel & - & laag \\
\hline WO sociale wetenschappen & - & laag \\
\hline WO kunst & - & gemiddeld \\
\hline WO kunstwetenschappen & - & gemiddeld \\
\hline
\end{tabular}

Bron: CBS/ROA 
Tabel 4.4

Percentage werknemers dat werkzaam is in ploegendienst, naar opleidingstype, 1996

\begin{tabular}{|c|c|c|}
\hline Opleidingstype & $\%$ & typering \\
\hline Basisonderwijs & 15 & hoog \\
\hline MAVO & 12 & gemiddeld \\
\hline VBO landbouw en natuurlijke omgeving & - & gemiddeld \\
\hline VBO landbouw en natuurlijke omgeving & - & gemiddeld \\
\hline VBO techniek & 15 & hoog \\
\hline $\begin{array}{l}\text { VBO bouwtechniek } \\
\text { VBO installatietechniek } \\
\text { VBO mechanische techniek } \\
\text { VBO fijnmechanische techniek } \\
\text { VBO motorvoertuigentechniek } \\
\text { VBO elektrotechniek } \\
\text { VBO grafische techniek } \\
\text { VBO brood en banket } \\
\text { VBO horeca en levensmiddelentechniek } \\
\text { VBO vervoer }\end{array}$ & $\begin{array}{r}12 \\
15 \\
- \\
15 \\
16 \\
- \\
22 \\
-\end{array}$ & $\begin{array}{l}\text { gemiddeld } \\
\text { gemiddeld } \\
\text { hoog } \\
\text { laag } \\
\text { hoog } \\
\text { hoog } \\
\text { gemiddeld } \\
\text { hoog } \\
\text { hoog } \\
\text { hoog }\end{array}$ \\
\hline VBO economie & 9 & gemiddeld \\
\hline VBO administratie, handel en textiel & 9 & gemiddeld \\
\hline VBO verzorging & 10 & gemiddeld \\
\hline VBO verzorging & 10 & gemiddeld \\
\hline VBO openbare orde en veiligheid & 53 & erg hoog \\
\hline VBO beveiliging & 53 & erg hoog \\
\hline HAVOIVWO & 9 & gemiddeld \\
\hline MBO/LLW landbouw en natuurlijke omgeving & - & gemiddeld \\
\hline $\begin{array}{l}\text { MBO/LLW landbouw en veeteelt } \\
\text { MBO/LLW milieu en groene ruimte }\end{array}$ & - & $\begin{array}{l}\text { gemiddeld } \\
\text { gemiddeld }\end{array}$ \\
\hline MBO/LLW techniek & 15 & hoog \\
\hline $\begin{array}{l}\text { MBO/LLW laboratorium } \\
\text { MBO/LLW bouw } \\
\text { MBO/LLW grond-, weg-en waterbouw } \\
\text { MBO/LLW installatietechniek } \\
\text { MBO/LLWW werktuigbouw en mechanische techniek } \\
\text { MBO/LLWW fijnmechanische techniek } \\
\text { MBO/LLWW motorvoertuigentechniek } \\
\text { MBO/LLWW vliegtuigtechniek } \\
\text { MBO/LLW operationele techniek } \\
\text { MBO/LLW elektrotechniek } \\
\text { MBO/LLW grafische techniek } \\
\text { MBO/LLW procestechniek } \\
\text { MBO/LLW brood en banket } \\
\text { MBO/LLW levensmiddelentechniek/vleesverwerking } \\
\text { MBO/LLW vervoer }\end{array}$ & $\begin{array}{r}- \\
5 \\
- \\
15 \\
12 \\
- \\
- \\
9 \\
22 \\
81 \\
- \\
24\end{array}$ & $\begin{array}{l}\text { hoog } \\
\text { gemiddeld } \\
\text { gemiddeld } \\
\text { gemiddeld } \\
\text { hoog } \\
\text { gemiddeld } \\
\text { gemiddeld } \\
\text { erg hoog } \\
\text { erg hoog } \\
\text { gemiddeld } \\
\text { hoog } \\
\text { erg hoog } \\
\text { erg hoog } \\
\text { hoog } \\
\text { hoog }\end{array}$ \\
\hline MBO/LLW dienstverlening en gezondheidszorg & 23 & hoog \\
\hline $\begin{array}{l}\text { MBO dokters-, tandarts- en dierenartsassistent } \\
\text { MBO/LLW apothekersassistent } \\
\text { MBO/LLW verpleging } \\
\text { MBO/LLW gezondheidstechniek }\end{array}$ & $\begin{array}{r}- \\
41 \\
-\end{array}$ & $\begin{array}{l}\text { gemiddeld } \\
\text { gemiddeld } \\
\text { erg hoog } \\
\text { laag }\end{array}$ \\
\hline
\end{tabular}


Tabel 4.4 (vervolg)

Percentage werknemers dat werkzaam is in ploegendienst, naar opleidingstype, 1996

\begin{tabular}{|c|c|c|}
\hline Opleidingstype & $\%$ & typering \\
\hline $\begin{array}{l}\text { MBO sociaal-cultureel } \\
\text { MBO/LLW verzorging } \\
\text { MBO/LLW uiterlijke verzorging } \\
\text { MBO/LLW horeca } \\
\text { MBO/LLW beweging en therapie }\end{array}$ & $\begin{array}{r}16 \\
27 \\
- \\
15 \\
-\end{array}$ & $\begin{array}{l}\text { hoog } \\
\text { erg hoog } \\
\text { gemiddeld } \\
\text { hoog } \\
\text { hoog }\end{array}$ \\
\hline MBO/LLW economie & 5 & gemiddeld \\
\hline $\begin{array}{l}\text { MBO/LLW administratie } \\
\text { MBO/LLW handel } \\
\text { MBO/LLW secretariaat } \\
\text { MBO/LLW toerisme en recreatie } \\
\text { MBO/LLW bedrijfskunde } \\
\text { MBO/LLW automatisering } \\
\text { MBO/LLW geld, bank en belastingen } \\
\text { MBO verzekeringswezen }\end{array}$ & $\begin{array}{l}4 \\
7 \\
- \\
- \\
- \\
- \\
- \\
-\end{array}$ & $\begin{array}{l}\text { gemiddeld } \\
\text { gemiddeld } \\
\text { laag } \\
\text { hoog } \\
\text { gemiddeld } \\
\text { gemiddeld } \\
\text { laag } \\
\text { erg laag }\end{array}$ \\
\hline MBO openbare orde en veiligheid & 36 & erg hoog \\
\hline MBO openbare orde en veiligheid & 36 & erg hoog \\
\hline HBO onderwijs en tolk en vertaler & 6 & gemiddeld \\
\hline $\begin{array}{l}\text { HBO lerarenopleiding basisonderwijs } \\
\text { HBO lerarenopleiding talen } \\
\text { HBO lerarenopleiding natuur en techniek } \\
\text { HBO lerarenopleiding economie en maatschappij } \\
\text { HBO lerarenopleiding lichamelijke opvoeding } \\
\text { HBO lerarenopleiding medisch en verzorging } \\
\text { HBO lerarenopleiding expressie } \\
\text { HBO tolk en vertaler }\end{array}$ & $\begin{array}{l}5 \\
- \\
- \\
- \\
- \\
- \\
- \\
-\end{array}$ & $\begin{array}{l}\text { gemiddeld } \\
\text { gemiddeld } \\
\text { laag } \\
\text { erg laag } \\
\text { gemiddeld } \\
\text { hoog } \\
\text { gemiddeld } \\
\text { gemiddeld }\end{array}$ \\
\hline HBO landbouw & - & laag \\
\hline $\begin{array}{l}\text { HBO landbouw en veeteelt } \\
\text { HBO milieukunde en levensmiddelentechnologie }\end{array}$ & - & $\begin{array}{l}\text { laag } \\
\text { laag }\end{array}$ \\
\hline HBO techniek & 5 & gemiddeld \\
\hline $\begin{array}{l}\text { HBO laboratorium } \\
\text { HBO bouwkunde } \\
\text { HBO civiele techniek } \\
\text { HBO werktuigbouwkunde } \\
\text { HBO elektrotechniek } \\
\text { HBO informatica } \\
\text { HBO chemische technologie } \\
\text { HBO vervoer en logistiek }\end{array}$ & $\begin{array}{l}- \\
- \\
- \\
- \\
- \\
25\end{array}$ & $\begin{array}{l}\text { gemiddeld } \\
\text { erg laag } \\
\text { erg laag } \\
\text { laag } \\
\text { erg laag } \\
\text { erg laag } \\
\text { hoog } \\
\text { erg hoog }\end{array}$ \\
\hline HBO paramedisch & 16 & hoog \\
\hline $\begin{array}{l}\text { HBO verpleegkunde } \\
\text { HBO (fysio)therapie } \\
\text { HBO voeding }\end{array}$ & $\begin{array}{r}23 \\
- \\
-\end{array}$ & $\begin{array}{l}\text { hoog } \\
\text { laag } \\
\text { gemiddeld }\end{array}$ \\
\hline HBO radiologie & - & gemiddeld \\
\hline HBO economie & - & laag \\
\hline $\begin{array}{l}\text { HBO accountancy en bedrijfseconomie } \\
\text { HBO commerciële economie } \\
\text { HBO toerisme en recreatie } \\
\text { HBO recht en bestuur } \\
\text { HBO secretariaat } \\
\text { HBO bedrifskunde }\end{array}$ & $\begin{array}{l}- \\
- \\
- \\
-\end{array}$ & $\begin{array}{l}\text { erg laag } \\
\text { erg laag } \\
\text { gemiddeld } \\
\text { laag } \\
\text { laag } \\
\text { laag }\end{array}$ \\
\hline
\end{tabular}


Tabel 4.4 (vervolg)

Percentage werknemers dat werkzaam is in ploegendienst, naar opleidingstype, 1996

\begin{tabular}{|c|c|c|}
\hline Opleidingstype & $\%$ & typering \\
\hline HBO sociaal-cultureel & 6 & gemiddeld \\
\hline $\begin{array}{l}\text { HBO communicatie en journalistiek } \\
\text { HBO maatschappelijk werk en hulpverlening } \\
\text { HBO personeelswerk } \\
\text { HBO bibliotheek en documentatie }\end{array}$ & $\begin{array}{r}10 \\
- \\
-\end{array}$ & $\begin{array}{l}\text { gemiddeld } \\
\text { gemiddeld } \\
\text { erg laag } \\
\text { erg laag }\end{array}$ \\
\hline HBO kunst & - & laag \\
\hline HBO uitvoerende en beeldende kunsten & - & laag \\
\hline HBO openbare orde en veiligheid & - & gemiddeld \\
\hline HBO openbare orde en veiligheid & - & gemiddeld \\
\hline WO letteren en theologie & - & laag \\
\hline $\begin{array}{l}\text { WO letteren } \\
\text { WO theologie }\end{array}$ & - & $\begin{array}{l}\text { laag } \\
\text { erg laag }\end{array}$ \\
\hline WO landbouw en milieukunde & - & laag \\
\hline WO landbouw en milieukunde & - & laag \\
\hline WO techniek & - & erg laag \\
\hline $\begin{array}{l}\text { WO wiskunde en natuurwetenschappen } \\
\text { WO bouwkunde } \\
\text { WO civiele techniek } \\
\text { WO werktuigbouwkunde } \\
\text { WO elektrotechniek } \\
\text { WO informatica en bestuurlijke informatiekunde }\end{array}$ & $\begin{array}{l}- \\
- \\
- \\
-\end{array}$ & $\begin{array}{l}\text { laag } \\
\text { erg laag } \\
\text { erg laag } \\
\text { erg laag } \\
\text { laag } \\
\text { erg laag }\end{array}$ \\
\hline WO medisch & - & gemiddeld \\
\hline $\begin{array}{l}\text { WO (dier)geneeskunde } \\
\text { WO tandheelkunde } \\
\text { WO farmacie }\end{array}$ & $\begin{array}{l}- \\
-\end{array}$ & $\begin{array}{l}\text { gemiddeld } \\
\text { erg laag } \\
\text { laag }\end{array}$ \\
\hline wo economie & - & erg laag \\
\hline $\begin{array}{l}\text { WO econom(etr)ie } \\
\text { WO bedrijfskunde } \\
\text { WO accountancy en belastingen } \\
\text { WO rechten en bestuurskunde }\end{array}$ & $\begin{array}{l}- \\
- \\
-\end{array}$ & $\begin{array}{l}\text { erg laag } \\
\text { erg laag } \\
\text { erg laag } \\
\text { erg laag }\end{array}$ \\
\hline WO sociaal-cultureel & - & laag \\
\hline WO sociale wetenschappen & - & laag \\
\hline WO kunst & - & laag \\
\hline WO kunstwetenschappen & - & laag \\
\hline
\end{tabular}

Bron: CBS/ROA 
Tabel 4.5

Percentage werknemers dat onder hoge tijdsdruk werkt, naar opleidingstype, 1996

\begin{tabular}{|c|c|c|}
\hline Opleidingstype & $\%$ & typering \\
\hline Basisonderwijs & 50 & erg laag \\
\hline MAVO & 53 & laag \\
\hline VBO landbouw en natuurlijke omgeving & 49 & erg laag \\
\hline VBO landbouw en natuurlijke omgeving & 49 & erg laag \\
\hline VBO techniek & 54 & laag \\
\hline $\begin{array}{l}\text { VBO bouwtechniek } \\
\text { VBO installatietechniek } \\
\text { VBO mechanische techniek } \\
\text { VBO fijnmechanische techniek } \\
\text { VBO motorvoertuigentechniek } \\
\text { VBO elektrotechniek } \\
\text { VBO grafische techniek } \\
\text { VBO brood en banket } \\
\text { VBO horeca en levensmiddelentechniek } \\
\text { VBO vervoer }\end{array}$ & $\begin{array}{r}49 \\
56 \\
5 \\
56 \\
56 \\
- \\
51 \\
59 \\
59\end{array}$ & $\begin{array}{l}\text { erg laag } \\
\text { laag } \\
\text { laag } \\
\text { laag } \\
\text { laag } \\
\text { laag } \\
\text { laag } \\
\text { laag } \\
\text { laag } \\
\text { laag }\end{array}$ \\
\hline VBO economie & 51 & laag \\
\hline VBO administratie, handel en textiel & 51 & laag \\
\hline VBO verzorging & 42 & erg laag \\
\hline VBO verzorging & 42 & erg laag \\
\hline VBO openbare orde en veiligheid & 49 & erg laag \\
\hline VBO beveiliging & 49 & erg laag \\
\hline HAVOIVWO & 63 & gemiddeld \\
\hline MBO/LLW landbouw en natuurlijke omgeving & 51 & laag \\
\hline $\begin{array}{l}\text { MBO/LLW landbouw en veeteelt } \\
\text { MBO/LLW milieu en groene ruimte }\end{array}$ & $\begin{array}{l}53 \\
47\end{array}$ & $\begin{array}{l}\text { laag } \\
\text { erg laag }\end{array}$ \\
\hline MBO/LLW techniek & 64 & gemiddeld \\
\hline $\begin{array}{l}\text { MBO/LLW laboratorium } \\
\text { MBO/LLW bouw } \\
\text { MBO/LLW grond-, weg- en waterbouw } \\
\text { MBO/LLW installatietechniek } \\
\text { MBO/LLW werktuigbouw en mechanische techniek } \\
\text { MBO/LLW fijnmechanische techniek } \\
\text { MBO/LLW motorvoertuigentechniek } \\
\text { MBO/LLW vliegtuigtechniek } \\
\text { MBO/LLW operationele techniek } \\
\text { MBO/LLW elektrotechniek } \\
\text { MBO/LLW grafische techniek } \\
\text { MBO/LLW procestechniek } \\
\text { MBO/LLW brood en banket } \\
\text { MBO/LLW levensmiddelentechniek/vleesverwerking } \\
\text { MBO/LLW vervoer }\end{array}$ & $\begin{array}{r}64 \\
58 \\
68 \\
65 \\
62 \\
66 \\
60 \\
- \\
69 \\
77 \\
62 \\
64 \\
55 \\
65\end{array}$ & $\begin{array}{l}\text { gemiddeld } \\
\text { laag } \\
\text { gemiddeld } \\
\text { gemiddeld } \\
\text { gemiddeld } \\
\text { gemiddeld } \\
\text { laag } \\
\text { hoog } \\
\text { laag } \\
\text { gemiddeld } \\
\text { hoog } \\
\text { gemiddeld } \\
\text { gemiddeld } \\
\text { laag } \\
\text { gemiddeld }\end{array}$ \\
\hline MBO/LLW dienstverlening en gezondheidszorg & 61 & gemiddeld \\
\hline $\begin{array}{l}\text { MBO dokters-, tandarts- en dierenartsassistent } \\
\text { MBO/LLW apothekersassistent } \\
\text { MBO/LLW verpleging } \\
\text { MBO/LLW gezondheidstechniek } \\
\text { MBO sociaal-cultureel }\end{array}$ & $\begin{array}{l}55 \\
62 \\
68 \\
50\end{array}$ & $\begin{array}{l}\text { laag } \\
\text { gemiddeld } \\
\text { gemiddeld } \\
\text { gemiddeld } \\
\text { laag }\end{array}$ \\
\hline
\end{tabular}


Tabel 4.5 (vervolg)

Percentage werknemers dat onder hoge tijdsdruk werkt, naar opleidingstype, 1996

\begin{tabular}{|c|c|c|}
\hline Opleidingstype & $\%$ & typering \\
\hline $\begin{array}{l}\text { MBO/LLW verzorging } \\
\text { MBO/LLW uiterlijke verzorging } \\
\text { MBO/LLW horeca } \\
\text { MBO/LLW beweging en therapie }\end{array}$ & $\begin{array}{l}63 \\
48 \\
68 \\
44\end{array}$ & $\begin{array}{l}\text { gemiddeld } \\
\text { erg laag } \\
\text { gemiddeld } \\
\text { erg laag }\end{array}$ \\
\hline MBO/LLW economie & 61 & gemiddeld \\
\hline $\begin{array}{l}\text { MBO/LLW administratie } \\
\text { MBO/LLW handel } \\
\text { MBO/LLW secretariaat } \\
\text { MBO/LLW toerisme en recreatie } \\
\text { MBO/LLW bedrijfskunde } \\
\text { MBO/LLW automatisering } \\
\text { MBO/LLW geld, bank en belastingen } \\
\text { MBO verzekeringswezen }\end{array}$ & $\begin{array}{l}63 \\
53 \\
59 \\
64 \\
79 \\
73 \\
71 \\
60\end{array}$ & $\begin{array}{l}\text { gemiddeld } \\
\text { laag } \\
\text { laag } \\
\text { gemiddeld } \\
\text { hoog } \\
\text { gemiddeld } \\
\text { gemiddeld } \\
\text { gemiddeld }\end{array}$ \\
\hline MBO openbare orde en veiligheid & 68 & gemiddeld \\
\hline MBO openbare orde en veiligheid & 68 & gemiddeld \\
\hline HBO onderwijs en tolk en vertaler & 57 & laag \\
\hline $\begin{array}{l}\text { HBO lerarenopleiding basisonderwijs } \\
\text { HBO lerarenopleiding talen } \\
\text { HBO lerarenopleiding natuur en techniek } \\
\text { HBO lerarenopleiding economie en maatschappij } \\
\text { HBO lerarenopleiding lichamelijke opvoeding } \\
\text { HBO lerarenopleiding medisch en verzorging } \\
\text { HBO lerarenopleiding expressie } \\
\text { HBO tolk en vertaler }\end{array}$ & $\begin{array}{r}50 \\
68 \\
64 \\
66 \\
44 \\
70 \\
64 \\
-\end{array}$ & $\begin{array}{l}\text { erg laag } \\
\text { gemidddeld } \\
\text { gemiddeld } \\
\text { gemiddeld } \\
\text { erg laag } \\
\text { gemidddeld } \\
\text { gemiddeld } \\
\text { gemiddeld }\end{array}$ \\
\hline HBO landbouw & 71 & gemiddeld \\
\hline $\begin{array}{l}\text { HBO landbouw en veeteelt } \\
\text { HBO milieukunde en levensmiddelentechnologie }\end{array}$ & 71 & $\begin{array}{l}\text { gemiddeld } \\
\text { gemiddeld }\end{array}$ \\
\hline HBO techniek & 76 & hoog \\
\hline $\begin{array}{l}\text { HBO laboratorium } \\
\text { HBO bouwkunde } \\
\text { HBO civiele techniek } \\
\text { HBO werktuigbouwkunde } \\
\text { HBO elektrotechniek } \\
\text { HBO informatica } \\
\text { HBO chemische technologie } \\
\text { HBO vervoer en logistiek }\end{array}$ & $\begin{array}{l}61 \\
83 \\
90 \\
73 \\
79 \\
82 \\
77\end{array}$ & $\begin{array}{l}\text { gemiddeld } \\
\text { erg hoog } \\
\text { erg hoog } \\
\text { hoog } \\
\text { hoog } \\
\text { erg hoog } \\
\text { gemiddeld } \\
\text { hoog }\end{array}$ \\
\hline HBO paramedisch & 70 & gemiddeld \\
\hline $\begin{array}{l}\text { HBO verpleegkunde } \\
\text { HBO (fysio)therapie } \\
\text { HBO voeding } \\
\text { HBO radiologie }\end{array}$ & $\begin{array}{r}78 \\
57 \\
- \\
-\end{array}$ & $\begin{array}{l}\text { hoog } \\
\text { laag } \\
\text { gemiddeld } \\
\text { gemiddeld }\end{array}$ \\
\hline HBO economie & 75 & hoog \\
\hline $\begin{array}{l}\text { HBO accountancy en bedrijfseconomie } \\
\text { HBO commerciële economie } \\
\text { HBO toerisme en recreatie } \\
\text { HBO recht en bestuur } \\
\text { HBO secretariaat } \\
\text { HBO bedrijfskunde }\end{array}$ & $\begin{array}{l}75 \\
78 \\
66 \\
79 \\
69 \\
77\end{array}$ & $\begin{array}{l}\text { hoog } \\
\text { hoog } \\
\text { gemiddeld } \\
\text { hoog } \\
\text { gemiddeld } \\
\text { hoog }\end{array}$ \\
\hline HBO sociaal-cultureel & 70 & gemiddeld \\
\hline HBO communicatie en journalistiek & 88 & erg hoog \\
\hline
\end{tabular}


Tabel 4.5 (vervolg)

Percentage werknemers dat onder hoge tijdsdruk werkt, naar opleidingstype, 1996

\begin{tabular}{|c|c|c|}
\hline Opleidingstype & $\%$ & typering \\
\hline $\begin{array}{l}\text { HBO maatschappelijk werk en hulpverlening } \\
\text { HBO personeelswerk } \\
\text { HBO bibliotheek en documentatie }\end{array}$ & $\begin{array}{l}67 \\
78 \\
52\end{array}$ & $\begin{array}{l}\text { gemiddeld } \\
\text { hoog } \\
\text { laag }\end{array}$ \\
\hline HBO kunst & 66 & gemiddeld \\
\hline HBO uitvoerende en beeldende kunsten & 66 & gemiddeld \\
\hline HBO openbare orde en veiligheid & 80 & hoog \\
\hline HBO openbare orde en veiligheid & 80 & hoog \\
\hline WO letteren en theologie & 76 & hoog \\
\hline $\begin{array}{l}\text { WO letteren } \\
\text { WO theologie }\end{array}$ & $\begin{array}{r}76 \\
-\end{array}$ & $\begin{array}{l}\text { hoog } \\
\text { gemiddeld }\end{array}$ \\
\hline WO landbouw en milieukunde & 73 & gemiddeld \\
\hline WO landbouw en milieukunde & 73 & gemiddeld \\
\hline WO techniek & 78 & hoog \\
\hline $\begin{array}{l}\text { WO wiskunde en natuurwetenschappen } \\
\text { WO bouwkunde } \\
\text { WO civiele techniek } \\
\text { WO werktuigbouwkunde } \\
\text { WO elektrotechniek } \\
\text { WO informatica en bestuurlijke informatiekunde }\end{array}$ & $\begin{array}{r}77 \\
- \\
77 \\
83 \\
-\end{array}$ & $\begin{array}{l}\text { hoog } \\
\text { erg hoog } \\
\text { hoog } \\
\text { hoog } \\
\text { erg hoog } \\
\text { gemiddeld }\end{array}$ \\
\hline WO medisch & 85 & erg hoog \\
\hline $\begin{array}{l}\text { WO (dier)geneeskunde } \\
\text { WO tandheelkunde } \\
\text { WO farmacie }\end{array}$ & $\begin{array}{r}85 \\
- \\
-\end{array}$ & $\begin{array}{l}\text { erg hoog } \\
\text { hoog } \\
\text { erg hoog }\end{array}$ \\
\hline WO economie & 81 & hoog \\
\hline $\begin{array}{l}\text { WO econom(etr)ie } \\
\text { WO bedrijfskunde } \\
\text { WO accountancy en belastingen } \\
\text { WO rechten en bestuurskunde }\end{array}$ & $\begin{array}{l}76 \\
82 \\
88 \\
82\end{array}$ & $\begin{array}{l}\text { hoog } \\
\text { erg hoog } \\
\text { erg hoog } \\
\text { erg hoog }\end{array}$ \\
\hline WO sociaal-cultureel & 80 & hoog \\
\hline WO sociale wetenschappen & 79 & hoog \\
\hline WO kunst & - & erg hoog \\
\hline WO kunstwetenschappen & - & erg hoog \\
\hline
\end{tabular}


Tabel 4.6

Mate van informatisering naar opleidingstype, $1996^{*}$

\begin{tabular}{|c|c|c|}
\hline Opleidingstype & $\%$ & typering \\
\hline Basisonderwijs & 17 & erg laag \\
\hline MAVO & 51 & gemiddeld \\
\hline VBO landbouw en natuurlijke omgeving & 16 & erg laag \\
\hline VBO landbouw en natuurlijke omgeving & 16 & erg laag \\
\hline VBO techniek & 21 & erg laag \\
\hline $\begin{array}{l}\text { VBO bouwtechniek } \\
\text { VBO installatietechniek } \\
\text { VBO mechanische techniek } \\
\text { VBO fijnmechanische techniek } \\
\text { VBO motorvoertuigentechniek } \\
\text { VBO elektrotechniek } \\
\text { VBO grafische techniek } \\
\text { VBO brood en banket } \\
\text { VBO horeca en levensmiddelentechniek } \\
\text { VBO vervoer }\end{array}$ & $\begin{array}{r}12 \\
22 \\
23 \\
33 \\
- \\
- \\
20 \\
-\end{array}$ & $\begin{array}{l}\text { erg laag } \\
\text { erg laag } \\
\text { laag } \\
\text { laag } \\
\text { laag } \\
\text { laag } \\
\text { laag } \\
\text { erg laag } \\
\text { erg laag } \\
\text { erg laag }\end{array}$ \\
\hline VBO economie & 42 & laag \\
\hline VBO administratie, handel en textiel & 42 & laag \\
\hline VBO verzorging & 23 & laag \\
\hline VBO verzorging & 23 & laag \\
\hline VBO openbare orde en veiligheid & 64 & gemiddeld \\
\hline VBO beveiliging & 64 & gemiddeld \\
\hline HAVO/VWO & 70 & gemiddeld \\
\hline MBO/LLW landbouw en natuurlijke omgeving & 30 & laag \\
\hline $\begin{array}{l}\text { MBO/LLW landbouw en veeteelt } \\
\text { MBO/LLW milieu en groene ruimte }\end{array}$ & $\begin{array}{l}30 \\
31\end{array}$ & $\begin{array}{l}\text { laag } \\
\text { laag }\end{array}$ \\
\hline MBO/LLW techniek & 49 & laag \\
\hline $\begin{array}{l}\text { MBO/LLW laboratorium } \\
\text { MBO/LLW bouw } \\
\text { MBO/LLW grond-, weg- en waterbouw } \\
\text { MBO/LLW installatietechniek } \\
\text { MBO/LLW werktuigbouw en mechanische techniek } \\
\text { MBO/LLW fijnmechanische techniek } \\
\text { MBO/LLW motorvoertuigentechniek } \\
\text { MBO/LLW vliegtuigtechniek } \\
\text { MBO/LLW operationele techniek } \\
\text { MBO/LLW elektrotechniek } \\
\text { MBO/LLW grafische techniek } \\
\text { MBO/LLW procestechniek } \\
\text { MBO/LLW brood en banket } \\
\text { MBO/LLW levensmiddelentechniek/vleesverwerking } \\
\text { MBO/LLW vervoer }\end{array}$ & $\begin{array}{r}83 \\
29 \\
52 \\
46 \\
60 \\
41 \\
- \\
61 \\
63 \\
81 \\
40 \\
58\end{array}$ & $\begin{array}{l}\text { gemiddeld } \\
\text { laag } \\
\text { gemiddeld } \\
\text { erg laag } \\
\text { laag } \\
\text { gemiddeld } \\
\text { laag } \\
\text { gemiddeld } \\
\text { laag } \\
\text { gemiddeld } \\
\text { gemiddeld } \\
\text { gemiddeld } \\
\text { erg laag } \\
\text { laag } \\
\text { gemiddeld }\end{array}$ \\
\hline MBO/LLW dienstverlening en gezondheidszorg & 37 & laag \\
\hline $\begin{array}{l}\text { MBO dokters-, tandarts- en dierenartsassistent } \\
\text { MBO/LLW apothekersassistent } \\
\text { MBO/LLW verpleging } \\
\text { MBO/LLW gezondheidstechniek } \\
\text { MBO sociaal-cultureel }\end{array}$ & $\begin{array}{r}73 \\
91 \\
39 \\
56\end{array}$ & $\begin{array}{l}\text { gemiddeld } \\
\text { hoog } \\
\text { laag } \\
\text { laag } \\
\text { gemiddeld }\end{array}$ \\
\hline
\end{tabular}


Tabel 4.6 (vervolg)

Mate van informatisering naar opleidingstype, 1996

\begin{tabular}{|c|c|c|}
\hline Opleidingstype & $\%$ & typering \\
\hline $\begin{array}{l}\text { MBO/LLW verzorging } \\
\text { MBO/LLW uiterlijke verzorging } \\
\text { MBO/LLW horeca } \\
\text { MBO/LLW beweging en therapie }\end{array}$ & $\begin{array}{l}22 \\
31 \\
37 \\
32\end{array}$ & $\begin{array}{l}\text { erg laag } \\
\text { laag } \\
\text { laag } \\
\text { laag }\end{array}$ \\
\hline MBO/LLW economie & 77 & gemiddeld \\
\hline $\begin{array}{l}\text { MBO/LLW administratie } \\
\text { MBO/LLW handel } \\
\text { MBO/LLW secretariaat } \\
\text { MBO/LLW toerisme en recreatie } \\
\text { MBO/LLW bedrijfskunde } \\
\text { MBO/LLW automatisering } \\
\text { MBO/LLW geld, bank en belastingen } \\
\text { MBO verzekeringswezen }\end{array}$ & $\begin{array}{l}86 \\
51 \\
90 \\
88 \\
87 \\
92 \\
97 \\
91\end{array}$ & $\begin{array}{l}\text { gemiddeld } \\
\text { gemiddeld } \\
\text { hoog } \\
\text { hoog } \\
\text { hoog } \\
\text { hoog } \\
\text { erg hoog } \\
\text { hoog }\end{array}$ \\
\hline MBO openbare orde en veiligheid & 76 & gemiddeld \\
\hline MBO openbare orde en veiligheid & 76 & gemiddeld \\
\hline HBO onderwijs en tolk en vertaler & 55 & gemiddeld \\
\hline $\begin{array}{l}\text { HBO lerarenopleiding basisonderwijs } \\
\text { HBO lerarenopleiding talen } \\
\text { HBO lerarenopleiding natuur en techniek } \\
\text { HBO lerarenopleiding economie en maatschappij } \\
\text { HBO lerarenopleiding lichamelijke opvoeding } \\
\text { HBO lerarenopleiding medisch en verzorging } \\
\text { HBO lerarenopleiding expressie } \\
\text { HBO tolk en vertaler }\end{array}$ & $\begin{array}{l}50 \\
56 \\
70 \\
64 \\
45 \\
62 \\
45 \\
-\end{array}$ & $\begin{array}{l}\text { gemiddeld } \\
\text { gemiddeld } \\
\text { gemiddeld } \\
\text { gemiddeld } \\
\text { laag } \\
\text { gemiddeld } \\
\text { laag } \\
\text { gemiddeld }\end{array}$ \\
\hline HBO landbouw & 89 & hoog \\
\hline $\begin{array}{l}\text { HBO landbouw en veeteelt } \\
\text { HBO milieukunde en levensmiddelentechnologie }\end{array}$ & $90^{-}$ & $\begin{array}{l}\text { gemiddeld } \\
\text { hoog }\end{array}$ \\
\hline HBO techniek & 90 & hoog \\
\hline $\begin{array}{l}\text { HBO laboratorium } \\
\text { HBO bouwkunde } \\
\text { HBO civiele techniek } \\
\text { HBO werktuigbouwkunde } \\
\text { HBO elektrotechniek } \\
\text { HBO informatica } \\
\text { HBO chemische technologie } \\
\text { HBO vervoer en logistiek }\end{array}$ & $\begin{array}{l}87 \\
83 \\
88 \\
90 \\
94 \\
97 \\
87 \\
82\end{array}$ & $\begin{array}{l}\text { gemiddeld } \\
\text { gemiddeld } \\
\text { hoog } \\
\text { hoog } \\
\text { erg hoog } \\
\text { erg hoog } \\
\text { hoog } \\
\text { gemiddeld }\end{array}$ \\
\hline HBO paramedisch & 57 & gemiddeld \\
\hline $\begin{array}{l}\text { HBO verpleegkunde } \\
\text { HBO (fysio)therapie } \\
\text { HBO voeding } \\
\text { HBO radiologie }\end{array}$ & $\begin{array}{r}55 \\
51 \\
- \\
88\end{array}$ & $\begin{array}{l}\text { gemiddeld } \\
\text { gemiddeld } \\
\text { gemiddeld } \\
\text { hoog }\end{array}$ \\
\hline HBO economie & 91 & hoog \\
\hline $\begin{array}{l}\text { HBO accountancy en bedrijfseconomie } \\
\text { HBO commerciële economie } \\
\text { HBO toerisme en recreatie } \\
\text { HBO recht en bestuur } \\
\text { HBO secretariaat } \\
\text { HBO bedrijfskunde }\end{array}$ & $\begin{array}{l}94 \\
91 \\
82 \\
87 \\
95 \\
90\end{array}$ & $\begin{array}{l}\text { erg hoog } \\
\text { hoog } \\
\text { gemiddeld } \\
\text { hoog } \\
\text { erg hoog } \\
\text { hoog }\end{array}$ \\
\hline HBO sociaal-cultureel & 78 & gemiddeld \\
\hline HBO communicatie en journalistiek & 92 & erg hoog \\
\hline
\end{tabular}


Tabel 4.6 (vervolg)

Mate van informatisering naar opleidingstype, 1996

\begin{tabular}{|c|c|c|}
\hline Opleidingstype & $\%$ & typering \\
\hline $\begin{array}{l}\text { HBO maatschappelijk werk en hulpverlening } \\
\text { HBO personeelswerk } \\
\text { HBO bibliotheek en documentatie }\end{array}$ & $\begin{array}{l}67 \\
91 \\
97\end{array}$ & $\begin{array}{l}\text { gemiddeld } \\
\text { hoog } \\
\text { erg hoog }\end{array}$ \\
\hline HBO kunst & 52 & gemiddeld \\
\hline $\mathrm{HBO}$ uitvoerende en beeldende kunsten & 52 & gemiddeld \\
\hline HBO openbare orde en veiligheid & 85 & gemiddeld \\
\hline HBO openbare orde en veiligheid & 85 & gemiddeld \\
\hline WO letteren en theologie & 80 & gemiddeld \\
\hline $\begin{array}{l}\text { WO letteren } \\
\text { WO theologie }\end{array}$ & $\begin{array}{r}81 \\
-\end{array}$ & $\begin{array}{l}\text { gemiddeld } \\
\text { gemiddeld }\end{array}$ \\
\hline WO landbouw en milieukunde & 92 & hoog \\
\hline WO landbouw en milieukunde & 92 & hoog \\
\hline WO techniek & 92 & hoog \\
\hline $\begin{array}{l}\text { WO wiskunde en natuurwetenschappen } \\
\text { WO bouwkunde } \\
\text { WO civiele techniek } \\
\text { WO werktuigbouwkunde } \\
\text { WO elektrotechniek } \\
\text { WO informatica en bestuurlijke informatiekunde }\end{array}$ & $\begin{array}{r}92 \\
89 \\
85 \\
90 \\
94 \\
100\end{array}$ & $\begin{array}{l}\text { hoog } \\
\text { hoog } \\
\text { gemiddeld } \\
\text { hoog } \\
\text { erg hoog } \\
\text { erg hoog }\end{array}$ \\
\hline WO medisch & 71 & gemiddeld \\
\hline $\begin{array}{l}\text { WO (dier)geneeskunde } \\
\text { WO tandheelkunde } \\
\text { WO farmacie }\end{array}$ & $\begin{array}{r}66 \\
- \\
-\end{array}$ & $\begin{array}{l}\text { gemiddeld } \\
\text { gemiddeld } \\
\text { erg hoog }\end{array}$ \\
\hline WO economie & 90 & hoog \\
\hline $\begin{array}{l}\text { WO econom(etr)ie } \\
\text { WO bedrijfskunde } \\
\text { WO accountancy en belastingen } \\
\text { WO rechten en bestuurskunde }\end{array}$ & $\begin{array}{l}92 \\
94 \\
98 \\
85\end{array}$ & $\begin{array}{l}\text { hoog } \\
\text { erg hoog } \\
\text { erg hoog } \\
\text { gemiddeld }\end{array}$ \\
\hline WO sociaal-cultureel & 82 & gemiddeld \\
\hline WO sociale wetenschappen & 84 & gemiddeld \\
\hline WO kunst & - & erg hoog \\
\hline WO kunstwetenschappen & - & erg hoog \\
\hline
\end{tabular}

Bron: CBS/ROA

* Onder 'informatisering' wordt verstaan het percentage werknemers dat gewoonlijk of soms met een computer werkt. 
Tabel 4.7

Verwachte krimp-kengetallen voor opleidingstypen per beroepssegment, 1997-2002

\begin{tabular}{lccc}
\hline Opleidingstype & $\begin{array}{l}\text { vraagafname } \\
\text { totaal }\end{array}$ & $\begin{array}{l}\text { netto } \\
\text { vraagafname }\end{array}$ & $\begin{array}{l}\text { bijdrage aan } \\
\text { vraagafname } \\
\text { opleidingstype } \\
\%\end{array}$ \\
\hline
\end{tabular}

\section{Basisonderwijs}

Elementaire beroepen 4,7

Lagere agrarische beroepen

Lagere technische beroepen

Lagere transportberoepen

Lagere administratieve, commerciële beroepen

Lagere verzorgende beroepen

Middelbare agrarische beroepen

Middelbare technische beroepen

Middelbare transportberoepen

Middelbare administratieve, commerciële beroepen

Middelbare verzorgende beroepen

Overige beroepen

$\begin{array}{llr}4,7 & 16 & 22 \\ 1,0 & 16 & 5 \\ 3,1 & 12 & 14 \\ 1,9 & 15 & 9 \\ 2,1 & 19 & 10 \\ 0,9 & 11 & 4 \\ 0,9 & 47 & 4 \\ 3,0 & 28 & 14 \\ 0,5 & 52 & 2 \\ 0,8 & 14 & 4 \\ 0,5 & 38 & 2 \\ 1,9 & 44 & 9\end{array}$

MAVO

Lagere agrarische beroepen

Lagere transportberoepen

Lagere administratieve, commerciële beroepen

Lagere beveiligingsberoepen

Middelbare technische beroepen

Middelbare (para)medische beroepen

Middelbare administratieve, commerciële beroepen

Middelbare verzorgende beroepen

Overige beroepen

$\begin{array}{lrr}0,2 & 6 & 5 \\ 0,5 & 11 & 15 \\ 0,2 & 1 & 7 \\ 0,1 & 12 & 4 \\ 0,1 & 2 & 3 \\ 0,1 & 5 & 2 \\ 1,2 & 7 & 40 \\ 0,2 & 11 & 7 \\ 0,5 & 39 & 16\end{array}$

\section{VBO landbouw en natuurlijke omgeving}

Lagere agrarische beroepen
Lagere technische beroepen
Lagere transportberoepen
Lagere administratieve, commerciële beroepen
Middelbare agrarische beroepen
Overige beroepen

VBO bouwtechniek

Elementaire beroepen

Lagere agrarische beroepen

Middelbare technische beroepen

Overige beroepen

VBO installatietechniek

Middelbare technische beroepen

VBO mechanische techniek

Lagere agrarische beroepen

Lagere technische beroepen

Lagere administratieve, commerciële beroepen

Middelbare technische beroepen

Middelbare administratieve, commerciële beroepen

Overige beroepen

\section{VBO fijnmechanische techniek}


Tabel 4.7 (vervolg)

Verwachte krimp-kengetallen voor opleidingstypen per beroepssegment, 1997-2002

\begin{tabular}{lccc}
\hline Opleidingstype & $\begin{array}{l}\text { vraagafname } \\
\text { totaal }\end{array}$ & $\begin{array}{l}\text { netto } \\
\text { vraagafname }\end{array}$ & $\begin{array}{l}\text { bijdrage aan } \\
\text { vraagafname } \\
\text { opleidingstype } \\
\%\end{array}$ \\
\hline
\end{tabular}

\section{VBO motorvoertuigentechniek}

Elementaire beroepen

0,1

Lagere technische beroepen

Middelbare technische beroepen

0,5

Overige beroepen

VBO elektrotechniek

Lagere technische beroepen

Middelbare technische beroepen

Overige beroepen

VBO grafische techniek

Overige beroepen

VBO brood en banket

Lagere technische beroepen

Overige beroepen

VBO horeca en levensmiddelentechniek

Lagere verzorgende beroepen

VBO vervoer

Lagere transportberoepen

VBO administratie, handel en textiel

Lagere agrarische beroepen

Lagere technische beroepen

Lagere administratieve, commerciële beroepen

Lagere verzorgende beroepen

Middelbare technische beroepen

Hogere admin., commerciële, economische beroepen

Overige beroepen

$\begin{array}{lrr}0,1 & 20 & 3 \\ 0,7 & 27 & 14 \\ 1,8 & 20 & 35 \\ 0,7 & 43 & 13 \\ 0,6 & 61 & 11 \\ 0,7 & 100 & 14 \\ 0,6 & 33 & 11\end{array}$

\section{VBO verzorging}

Lagere agrarische beroepen

Lagere technische beroepen

Lagere verzorgende beroepen

Overige beroepen

VBO beveiliging

\section{HAVO/VWO}

Lagere (para)medische beroepen

Middelbare (para)medische beroepen

Middelbare juridische, bestuurl. beveiligingsberoepen

Middelbare taalkundige, culturele beroepen

Hogere pedagogische beroepen

Hogere taalkundige, culturele beroepen 
Tabel 4.7 (vervolg)

Verwachte krimp-kengetallen voor opleidingstypen per beroepssegment, 1997-2002

\begin{tabular}{lccc}
\hline Opleidingstype & $\begin{array}{c}\text { vraagafname } \\
\text { totaal }\end{array}$ & $\begin{array}{c}\text { netto } \\
\text { vraagafname }\end{array}$ & $\begin{array}{c}\text { bijdrage aan } \\
\text { vraagafname } \\
\text { opleidingstype } \\
\%\end{array}$ \\
\hline $\begin{array}{l}\text { Hogere beroepen mbt gedrag en maatschappij } \\
\text { Overige beroepen }\end{array}$ & 0,3 & 27 & 18 \\
MBO/LLW landbouw en veeteelt & 0,2 & 19 & 13 \\
$\begin{array}{l}\text { Middelbare administratieve, commerciële beroepen } \\
\text { Overige beroepen }\end{array}$ & 0,3 & 16 & 64 \\
\hline
\end{tabular}

MBO/LLW milieu en groene ruimte

Overige beroepen

0

0

0

MBO/LLW laboratorium

Middelbare wiskundige, natuurwetensch. beroepen Overige beroepen

$\begin{array}{lrr}0,1 & 8 & 50 \\ 0,1 & 33 & 50\end{array}$

\section{MBO/LLW bouw}

Hogere technische beroepen

0,1

5

100

MBO/LLW grond-, weg- en waterbouw

Overige beroepen

MBO/LLW installatietechniek

Overige beroepen

MBO/LLW werktuigbouw en mechanische techniek

Middelbare administratieve, commerciële beroepen Hogere technische beroepen

Hogere admin., commerciële, economische beroepen Overige beroepen

MBO/LLW fijnmechanische techniek

Overige beroepen

MBO/LLW motorvoertuigentechniek

Middelbare administratieve, commerciële beroepen Overige beroepen

MBO/LLW vliegtuigtechniek

Overige beroepen

MBO/LLW operationele techniek

Overige beroepen

MBO/LLW elektrotechniek

Hogere technische beroepen

Hogere admin., commerciële, economische beroepen

MBO/LLW grafische techniek

$\begin{array}{ll}6 & 46 \\ 7 & 54\end{array}$


Tabel 4.7 (vervolg)

Verwachte krimp-kengetallen voor opleidingstypen per beroepssegment, 1997-2002

\begin{tabular}{lccc}
\hline Opleidingstype & $\begin{array}{c}\text { vraagafname } \\
\text { totaal }\end{array}$ & $\begin{array}{c}\text { netto } \\
\text { vraagafname }\end{array}$ & $\begin{array}{c}\text { bijdrage aan } \\
\text { vraagafname } \\
\text { opleidingstype } \\
\%\end{array}$ \\
\hline $\begin{array}{l}\% \\
\text { Middelbare technische beroepen }\end{array}$ & 0,6 & 16 & 58 \\
Overige beroepen & 0,4 & 31 & 40 \\
MBO/LLW procestechniek & & & \\
Lagere technische beroepen & 0,3 & 32 & 76 \\
Overige beroepen & 0,1 & 19 & 24
\end{tabular}

\section{MBO/LLW brood en banket}

Middelbare technische beroepen

Overige beroepen

0,3

MBO/LLW levensmiddelentechniek/vleesverwerking

Middelbare technische beroepen

\section{MBO/LLW administratie}

Lagere administratieve, commerciële beroepen

Middelbare technische beroepen

Middelbare juridische, bestuur. beveiligingsberoepen

Hogere admin., commerciële, economische beroepen

Overige beroepen

$\begin{array}{rrr}1,4 & 18 & 43 \\ 0 & 3 & 1 \\ 0 & 0 & 0 \\ 0,7 & 8 & 22 \\ 1,1 & 48 & 34\end{array}$

\section{MBO/LLW vervoer}

Middelbare docenten transport-, sportvakken

Middelbare transportberoepen

Overige beroepen

MBO dokters-, tandarts- en dierenartsassistent

Overige beroepen

MBO/LLW apothekersassistent

Overige beroepen

\section{MBO/LLW verpleging}

Middelbare (para)medische beroepen

Middelbare administratieve, commerciële beroepen

Hogere (para)medische beroepen

Overige beroepen

MBO sociaal-cultureel

Middelbare taalkundige, culturele beroepen

Overige beroepen

MBO/LLW verzorging

Lagere (para)medische beroepen

Lagere administratieve, commerciële beroepen

\section{MBO/LLW horeca}


Tabel 4.7 (vervolg)

Verwachte krimp-kengetallen voor opleidingstypen per beroepssegment, 1997-2002

\begin{tabular}{lccc}
\hline Opleidingstype & $\begin{array}{l}\text { vraagafname } \\
\text { totaal }\end{array}$ & $\begin{array}{l}\text { netto } \\
\text { vraagafname }\end{array}$ & $\begin{array}{l}\text { bijdrage aan } \\
\text { vraagafname } \\
\text { opleidingstype } \\
\%\end{array}$ \\
\hline
\end{tabular}

MBO/LLW beweging en therapie

Overige beroepen

0,6

41

100

MBO/LLW handel

Lagere agrarische beroepen

$\begin{array}{rrr}0,3 & 40 & 10 \\ 0,4 & 10 & 15 \\ 0,3 & 36 & 11 \\ 0,1 & 5 & 3 \\ 0,4 & 7 & 13 \\ 0 & 0 & 2 \\ 1,0 & 17 & 35 \\ 0,3 & 47 & 11\end{array}$

Lagere technische beroepen

Lagere verzorgende beroepen

Middelbare agrarische beroepen

Middelbare technische beroepen

Middelbare administratieve, commerciële beroepen

Hogere admin., commerciële, economische beroepen

Overige beroepen

0,1

11

Elementaire beroepen

Overige beroepen

0,2

17

36

MBO/LLW toerisme en recreatie

Overige beroepen

0

0

0

MBO openbare orde en veiligheid

Lagere beveiligingsberoepen

Middelbare technische beroepen

Middelbare juridische, bestuur. beveiligingsberoepen

Overige beroepen

HBO lerarenopleiding basisonderwijs

Lagere administratieve, commerciële beroepen

Hogere admin., commerciële, economische beroepen

HBO lerarenopleiding talen

Hogere pedagogische beroepen

Overige beroepen

HBO lerarenopleiding natuur en techniek

Overige beroepen

HBO lerarenopleiding economie en maatschappij

Overige beroepen

HBO lerarenopleiding lichamelijke opvoeding

Hogere pedagogische beroepen

$\mathrm{HBO}$ lerarenopleiding medisch en verzorging 
Tabel 4.7 (vervolg)

Verwachte krimp-kengetallen voor opleidingstypen per beroepssegment, 1997-2002

\begin{tabular}{lccc}
\hline Opleidingstype & $\begin{array}{c}\text { vraagafname } \\
\text { totaal }\end{array}$ & $\begin{array}{l}\text { netto } \\
\text { vraagafname }\end{array}$ & $\begin{array}{c}\text { bijdrage aan } \\
\text { vraagafname } \\
\text { opleidingstype } \\
\%\end{array}$ \\
\hline
\end{tabular}

HBO lerarenopleiding expressie

Hogere pedagogische beroepen

Overige beroepen

0,2

35

HBO tolk en vertaler

Overige beroepen

0

6
38

HBO landbouw en veeteelt

Overige beroepen

0

0

0

HBO milieukunde en levensmiddelentechnologie

Overige beroepen

HBO laboratorium

Hogere wiskundige, natuurwetensch. beroepen

Hogere technische beroepen

0,3

0,1

Hogere (para)medische beroepen

Overige beroepen

HBO bouwkunde

Overige beroepen

HBO civiele techniek

Hogere technische beroepen

Overige beroepen

3

HBO werktuigbouwkunde

Middelbare technische beroepen

Overige beroepen

HBO elektrotechniek

Overige beroepen

HBO informatica

Overige beroepen

HBO chemische technologie

Overige beroepen

HBO vervoer en logistiek

Middelbare technische beroepen

\section{HBO verpleegkunde}

Middelbare (para)medische beroepen

HВO (fysio)therapie 
Tabel 4.7 (vervolg)

Verwachte krimp-kengetallen voor opleidingstypen per beroepssegment, 1997-2002

\begin{tabular}{lccc}
\hline Opleidingstype & $\begin{array}{l}\text { vraagafname } \\
\text { totaal }\end{array}$ & $\begin{array}{l}\text { netto } \\
\text { vraagafname }\end{array}$ & $\begin{array}{l}\text { bijdrage aan } \\
\text { vraagafname } \\
\text { opleidingstype } \\
\%\end{array}$ \\
\hline
\end{tabular}

HBO voeding

Overige beroepen

0

0

0

HBO accountancy en bedrijfseconomie

Middelbare administratieve, commerciële beroepen

Overige beroepen

$\begin{array}{lll}0,3 & 15 & 29 \\ 0,6 & 39 & 71\end{array}$

HBO commerciële economie

Overige beroepen

0

0

HBO toerisme en recreatie

Overige beroepen

0

0

0

HBO recht en bestuur

Overige beroepen

0

0

0

HBO secretariaat

Overige beroepen

0,6

64

HBO bedrijfskunde

Managers (wetenschappelijk werk- en denkniveau) Overige beroepen

HBO communicatie en journalistiek

Overige beroepen

0

0

HBO maatschappelijk werk en hulpverlening

Middelbare beroepen mbt gedrag en maatschappij

Middelbare verzorgende beroepen

0,1

0,2

0,5

12

Overige beroepen

9
32

HBO personeelswerk

Hogere beroepen mbt gedrag en maatschappij

HBO bibliotheek en documentatie

Overige beroepen

HBO uitvoerende en beeldende kunsten

Hogere pedagogische beroepen

HBO openbare orde en veiligheid

Overige beroepen

\section{WO letteren}

Overige beroepen 
Tabel 4.7 (vervolg)

Verwachte krimp-kengetallen voor opleidingstypen per beroepssegment, 1997-2002

\begin{tabular}{lccc}
\hline Opleidingstype & $\begin{array}{l}\text { vraagafname } \\
\text { totaal }\end{array}$ & $\begin{array}{l}\text { netto } \\
\text { vraagafname }\end{array}$ & $\begin{array}{l}\text { bijdrage aan } \\
\text { vraagafname } \\
\text { opleidingstype } \\
\%\end{array}$ \\
\hline
\end{tabular}

WO theologie

Wetenschappelijke beroepen mbt gedrag en maatschappij Overige beroepen

Wo landbouw en milieukunde

Overige beroepen

WO wiskunde en natuurwetenschappen

Wetenschappelijke wiskundige, natuurw. beroepen Overige beroepen

wo bouwkunde

Overige beroepen

WO civiele techniek

Overige beroepen

0

WO werktuigbouwkunde

Overige beroepen

WO elektrotechniek

Overige beroepen

WO informatica en bestuurlijke informatiekunde

Overige beroepen

\section{WO (dier)geneeskunde}

Overige beroepen

WO tandheelkunde

Overige beroepen

WO farmacie

Wetenschappelijke (para)medische beroepen Overige beroepen

\section{WO econom(etr)ie}

Wetenschappelijke pedagogische beroepen Overige beroepen

wo bedrijfskunde

WO accountancy en belastingen 
Tabel 4.7 (vervolg)

Verwachte krimp-kengetallen voor opleidingstypen per beroepssegment, 1997-2002

\begin{tabular}{lccc}
\hline Opleidingstype & $\begin{array}{l}\text { vraagafname } \\
\text { totaal }\end{array}$ & $\begin{array}{l}\text { netto } \\
\text { vraagafname }\end{array}$ & $\begin{array}{l}\text { bijdrage aan } \\
\text { vraagafname } \\
\text { opleidingstype } \\
\%\end{array}$ \\
\hline
\end{tabular}

WO rechten en bestuurskunde

Hogere admin., commerciële, econ. beroepen

Overige beroepen

$\begin{array}{lrl}0,1 & 7 & 39 \\ 0,1 & 15 & 61\end{array}$

WO sociale wetenschappen

Wetenschappelijke pedagogische beroepen Overige beroepen

\section{WO kunstwetenschappen}

Overige beroepen

Bron: ROA 
Tabel 4.8

Opleidingseffect naar opleidingstype, 1997-2002

Opleidingstype

Basisonderwijs

Basisonderwijs

MBO, VBO

MAVO

VBO landbouw en natuurlijke omgeving

VBO bouwtechniek

VBO installatietechniek

VBO mechanische techniek

VBO fijnmechanische techniek

VBO motorvoertuigentechniek

VBO elektrotechniek

VBO grafische techniek

VBO brood en banket

VBO horeca en levensmiddelentechniek

VBO vervoer

VBO administratie, handel en textiel

VBO verzorging

VBO beveiliging

HAVO/VWO, MBO/LLW

HAVONWO

MBO/LLW landbouw en veeteelt

$\mathrm{MBO} / \mathrm{LW}$ milieu en groene ruimte

MBO/LLW laboratorium

MBO/LLW bouw

MBO/LLW grond-, weg- en waterbouw

$\mathrm{MBO} / \mathrm{LLW}$ installatietechniek

MBO/LLW werktuigbouw en mechanische techniek

MBO/LLW fijnmechanische techniek

$\mathrm{MBO} / \mathrm{LLW}$ motorvoertuigentechniek

MBO/LLW vliegtuigtechniek

MBO/LLW operationele techniek

MBO/LLW elektrotechniek

$\mathrm{MBO} / \mathrm{LLW}$ grafische techniek

MBO/LLW procestechniek

MBO/LLW brood en banket

MBO/LLW levensmiddelentechniek/vleesverwerking

MBO/LLW vervoer

MBO dokters-, tandarts- en dierenartsassistent

MBO/LLW apothekersassistent

MBO/LLW verpleging

MBO sociaal-cultureel

MBO/LLW verzorging

MBO/LLW uiterlijke verzorging

MBO/LLW horeca

$\mathrm{MBO} / \mathrm{LLW}$ bewegingen therapie

MBO/LLW administratie

$\mathrm{MBO} / \mathrm{LLW}$ handel

MBO/LLW secretariaat

MBO/LLW toerisme en recreatie

MBO openbare orde en veiligheid

HBO

HBO lerarenopleiding basisonderwijs

HBO lerarenopleiding talen

HBO lerarenopleiding natuur en techniek

HBO lerarenopleiding economie en maatschappij

HBO lerarenopleiding lichamelijke opvoeding

HBO lerarenopleiding medisch en verzorging

HBO lerarenopleiding expressie

HBO tolk en vertaler 
Tabel 4.8 (vervolg)

Opleidingseffect naar opleidingstype, 1997-2002

Opleidingstype

$\mathrm{HBO}$ landbouw en veeteelt

HBO milieukunde en levensmiddelentechnologie

HBO laboratorium

HBO bouwkunde

HBO civiele techniek

HBO werktuigbouwkunde

HBO elektrotechniek

HBO informatica

$\mathrm{HBO}$ chemische technologie

HBO vervoer en logistiek

$\mathrm{HBO}$ verpleegkunde

HBO (fysio)therapie

$\mathrm{HBO}$ voeding

HBO accountancy en bedrijfseconomie

$\mathrm{HBO}$ commerciële economie

HBO toerisme en recreatie

HBO recht en bestuur

HBO secretariaat

HBO bedrijfskunde

HBO communicatie en journalistiek

HBO maatschappelijk werk en hulpverlening

HBO personeelswerk

HBO bibliotheek en documentatie

HBO uitvoerende en beeldende kunsten

HBO openbare orde en veiligheid

wo

WO letteren

WO theologie

WO landbouw en milieukunde

WO wiskunde en natuurwetenschappen

WO bouwkunde

WO civiele techniek

WO werktuigbouwkunde

WO elektrotechniek

WO informatica en bestuurlijke informatiekunde

WO (dier)geneeskunde

WO tandheelkunde

WO farmacie

WO econom(etr)ie

WO bedrijfskunde

WO accountancy en belastingen

WO rechten en bestuurskunde

WO sociale wetenschappen

WO kunstwetenschappen

Bron: ROA 
Tabel 4.9

Percentage werkenden dat deelneemt aan bedrijfsopleidingen, naar opleidingsrichting, 1995-1996

\begin{tabular}{|c|c|c|c|}
\hline Opleidingsrichting & $\%$ & typering & trend \\
\hline $\begin{array}{l}\text { Basisonderwijs } \\
\text { MAVO } \\
\text { VBO landbouw en natuurlijke omgeving } \\
\text { VBO techniek } \\
\text { VBO economie } \\
\text { VBO verzorging } \\
\text { VBO openbare orde en veiligheid } \\
\text { HAVO/VWO } \\
\text { MBO/LLW landbouw en natuurlijke omgeving } \\
\text { MBO/LLW techniek } \\
\text { MBO/LLW dienstverlening en gezondheidszorg } \\
\text { MBO/LLW economie } \\
\text { MBO openbare orde en veiligheid } \\
\text { HBO onderwijs en tolk en vertaler } \\
\text { HBO landbouw } \\
\text { HBO techniek } \\
\text { HBO paramedisch } \\
\text { HBO economie } \\
\text { HBO sociaal-cultureel } \\
\text { HBO kunst } \\
\text { HBO openbare orde en veiligheid } \\
\text { WO letteren en theologie } \\
\text { WO landbouw en milieukunde } \\
\text { WO techniek } \\
\text { WO medisch } \\
\text { WO economie } \\
\text { WO sociaal-cultureel } \\
\text { WO kunst }\end{array}$ & $\begin{array}{r}2 \\
5 \\
- \\
5 \\
4 \\
3 \\
- \\
6 \\
2 \\
6 \\
5 \\
5 \\
10 \\
5 \\
- \\
5 \\
4 \\
6 \\
3 \\
- \\
- \\
- \\
- \\
3 \\
5 \\
3 \\
3 \\
-\end{array}$ & $\begin{array}{l}\text { laag } \\
\text { gemiddeld } \\
\text { erg laag } \\
\text { hoog } \\
\text { gemiddeld } \\
\text { gemiddeld } \\
- \\
\text { erg hoog } \\
\text { laag } \\
\text { hoog } \\
\text { hoog } \\
\text { gemiddeld } \\
\text { erg hoog } \\
\text { gemiddeld } \\
- \\
\text { hoog } \\
\text { gemiddeld } \\
\text { hoog } \\
\text { gemiddeld } \\
\text { erg laag } \\
- \\
\text { laag } \\
- \\
\text { gemiddeld } \\
\text { gemiddeld } \\
\text { gemiddeld } \\
\text { gemiddeld } \\
-\end{array}$ & $\begin{array}{l}\text { sterk dalend } \\
\text { dalend } \\
\text { dalend } \\
\text { dalend } \\
\text { fluctuerend } \\
\text { fluctuerend } \\
\text { fluctuerend } \\
\text { fluctuerend } \\
\text { fluctuerend } \\
\text { fluctuerend } \\
\text { dalend } \\
\text { fluctuerend } \\
\text { fluctuerend } \\
\text { fluctuerend } \\
\text { sterk dalend } \\
\text { fluctuerend } \\
\text { fluctuerend } \\
\text { fluctuerend } \\
\text { sterk stijgend } \\
\text { fluctuerend } \\
\text { sterk dalend } \\
\text { sterk stijgend } \\
\text { sterk dalend } \\
\text { fluctuerend } \\
\text { fluctuerend } \\
\text { fluctuerend } \\
\text { fluctuerend } \\
\text { fluctuerend }\end{array}$ \\
\hline
\end{tabular}

Bron: CBS/ROA 
Tabe/ 4.10

Employability-indicatoren naar opleidingsrichting, 1996

\begin{tabular}{|c|c|c|c|c|}
\hline Opleidingsrichting & $\begin{array}{c}\text { niet } \\
\text { mobiel } \\
\%\end{array}$ & $\begin{array}{c}\text { niet actief } \\
\text { zoekend } \\
\%\end{array}$ & $\begin{array}{c}\text { niet breed } \\
\text { inzetbaar } \\
\%\end{array}$ & $\begin{array}{c}\text { ervarings- } \\
\text { concentratie } \\
\%\end{array}$ \\
\hline Basisonderwijs & 72 & 92 & 33 & 37 \\
\hline MAVO & 74 & 94 & 24 & 24 \\
\hline VBO landbouw en natuurlijke omgeving & 67 & 93 & 29 & 23 \\
\hline VBO techniek & 73 & 91 & 22 & 28 \\
\hline VBO economie & 60 & 84 & 33 & 18 \\
\hline VBO verzorging & 67 & 92 & 40 & 25 \\
\hline VBO openbare orde en veiligheid & - & - & - & - \\
\hline $\begin{array}{l}\text { HAVO/NWO } \\
\text { MBO/LLW landbouw en natuurlijke }\end{array}$ & 60 & 89 & 24 & 18 \\
\hline omgeving & 57 & 96 & 25 & 26 \\
\hline MBO/LLW techniek & 69 & 87 & 23 & 19 \\
\hline MBO/LLW dienstverlening en & & & & \\
\hline gezondheidszorg & 69 & 95 & 36 & 17 \\
\hline MBO/LLW economie & 59 & 86 & 19 & 13 \\
\hline MBO openbare orde en veiligheid & 67 & 89 & 19 & 10 \\
\hline HBO onderwijs en tolk en vertaler & 78 & 93 & 34 & 44 \\
\hline HBO landbouw & 80 & 100 & 21 & 7 \\
\hline HBO techniek & 64 & 91 & 26 & 20 \\
\hline HBO paramedisch & 79 & 97 & 53 & 29 \\
\hline HBO economie & 60 & 91 & 13 & 8 \\
\hline HBO sociaal-cultureel & 67 & 91 & 25 & 18 \\
\hline HBO kunst & 42 & 80 & 27 & 27 \\
\hline HBO openbare orde en veiligheid & - & - & - & - \\
\hline WO letteren en theologie & 70 & 89 & 20 & 32 \\
\hline WO landbouw en milieukunde & - & - & - & - \\
\hline WO techniek & 78 & 84 & 31 & 19 \\
\hline WO medisch & - & - & - & - \\
\hline WO economie & 60 & 68 & 13 & 17 \\
\hline WO kunst & - & - & - & - \\
\hline
\end{tabular}

Bron: OSA/ROA 
Tabel 4.11

Overzicht van perspectiefrijke omscholingsmogelijkheden naar andere opleidingstypen per opleidingsrichting

$\begin{array}{lll}\text { Opleidingsrichting } & \text { ITA } & \text { typering } \\ \text { Perspectiefrijke opleidingstypen } & \text { in } 2002 & \end{array}$

Basisonderwijs

MAVO*

VBO mechanische techniek

0.97 goed

MAVO

MBO/LLW administratie*

VBO landbouw en natuurlijke omgeving

MBO/LLW landbouw en veeteelt*

$\mathrm{MBO} / \mathrm{LLW}$ milieu en groene ruimte

0.93 goed

VBO techniek

\author{
MBO/LLW bouw \\ $\mathrm{MBO} / \mathrm{LLW}$ installatietechniek \\ VBO fijnmechanische techniek ${ }^{*}$ \\ MBO/LLW werktuigbouw en mechanische techniek \\ VBO mechanische techniek \\ MBO/LLW vliegtuigtechniek \\ MBO/LLW motorvoertuigentechniek \\ MBO/LLW elektrotechniek* \\ MBO/LLW levensmiddelentechniek/vleesverwerking* \\ MBO/LLW horeca*
}

0.96 goed

VBO economie

MAVO

$\begin{array}{ll}0.87 & \text { goed } \\ 0.92 & \text { goed } \\ 0.94 & \text { goed } \\ 0.95 & \text { goed } \\ 0.98 & \text { goed } \\ 0.94 & \text { goed } \\ 0.91 & \text { goed } \\ 0.93 & \text { goed } \\ 0.99 & \text { goed } \\ 0.85 & \text { zeer goed }\end{array}$

VBO verzorging

VBO openbare orde en veiligheid

\title{
HAVO/VWO
}

MBO/LLW administratie*

MBO/LLW landbouw en natuurlijke omgeving

MBO/LLW landbouw en veeteelt

$0.97 \quad$ goed

$\mathrm{MBO} / \mathrm{LLW}$ milieu en groene ruimte

MBO/LLW techniek

MBO/LLW installatietechniek

MBO/LLW operationele techniek

HBO civiele techniek ${ }^{*}$

MBO/LLW fijmechanische techniek*

MBO/LLW vliegtuigtechniek

MBO/LLW werktuigbouw en mechanische techniek

MBO/LLW motorvoertuigentechniek

goed

MBO/LLW grond-, weg-en waterbouw*

MBO/LLW levensmiddelentechniek/vleesverwerking*

$\begin{array}{ll}0.92 & \text { goed } \\ 0.80 & \text { zeer goed } \\ 0.86 & \text { goed } \\ 0.93 & \text { goed } \\ 0.94 & \text { goed } \\ 0.95 & \text { goed } \\ 0.91 & \text { goed } \\ 0.90 & \text { goed } \\ 0.99 & \text { goed }\end{array}$


Tabel 4.11 (vervolg)

Overzicht van perspectiefrijke omscholingsmogelijkheden naar andere opleidingstypen per opleidingsrichting

\begin{tabular}{lll}
$\begin{array}{l}\text { Opleidingsrichting } \\
\text { Perspectiefrijke opleidingstypen }\end{array}$ & $\begin{array}{l}\text { ITA } \\
\text { in } 2002\end{array}$ & typering \\
\hline
\end{tabular}

MBO/LLW dienstverlening en gezondheidszorg

MBO/LLW verpleging

MBO/LLW apothekersassistent*

$0.81 \quad$ zeer goed

MBO economie

MBO verzekeringswezen*

MBO/LLW administratie*

$0.96 \quad$ goed

MBO openbare orde en veiligheid

HBO onderwijs en tolk en vertaler

HBO lerarenopleiding expressie

HBO lerarenopleiding medisch en verzorging

0.98 goed

HBO landbouw

$\mathrm{HBO}$ landbouw en veeteelt

HBO techniek

HBO bedrijfskunde*

HBO informatica*

HBO elektrotechniek*

$\begin{array}{ll}0.97 & \text { goed } \\ 0.85 & \text { zeer goed } \\ 0.93 & \text { goed }\end{array}$

HBO paramedisch

HBO (fysio)therapie

$\mathrm{HBO}$ voeding

HBO verpleegkunde

HBO laboratorium

0.92 goed

1.00 goed

HBO economie

0.87

goed

HBO economie

WO accountancy en belastingen ${ }^{*}$

HBO bedrijfskunde*

HBO accountancy en bedrijfseconomie*

HBO werktuigbouwkunde

0.96

goed

HBO sociaal-cultureel

HBO kunst

HBO openbare orde en veiligheid

WO letteren en theologie

WO landbouw en milieukunde 
Tabel 4.11 (vervolg)

Overzicht van perspectiefrijke omscholingsmogelijkheden naar andere opleidingstypen per opleidingsrichting

Opleidingsrichtin

ITA

typering

Perspectiefrijke opleidingstypen

in 2002

\section{WO techniek}

WO civiele techniek ${ }^{*}$

WO bouwkunde*

WO werktuigbouwkunde*

WO elektrotechniek

$0.73 \quad$ zeer goed

0.78 zeer goed

0.87

goed

WO medisch

WO tandheelkunde

WO (dier)geneeskunde

0.81 zeer goed

wo economie

WO sociaal-cultureel

\section{wo kunst}

wO letteren

goed

${ }^{*}=$ Deze opleidingstypen worden naast goede arbeidsmarktperspectieven bovendien gekenmerkt door een lagere fysieke belasting. Bron: ROA 
RISICOPROFIELEN NAAR OPLEIDING 


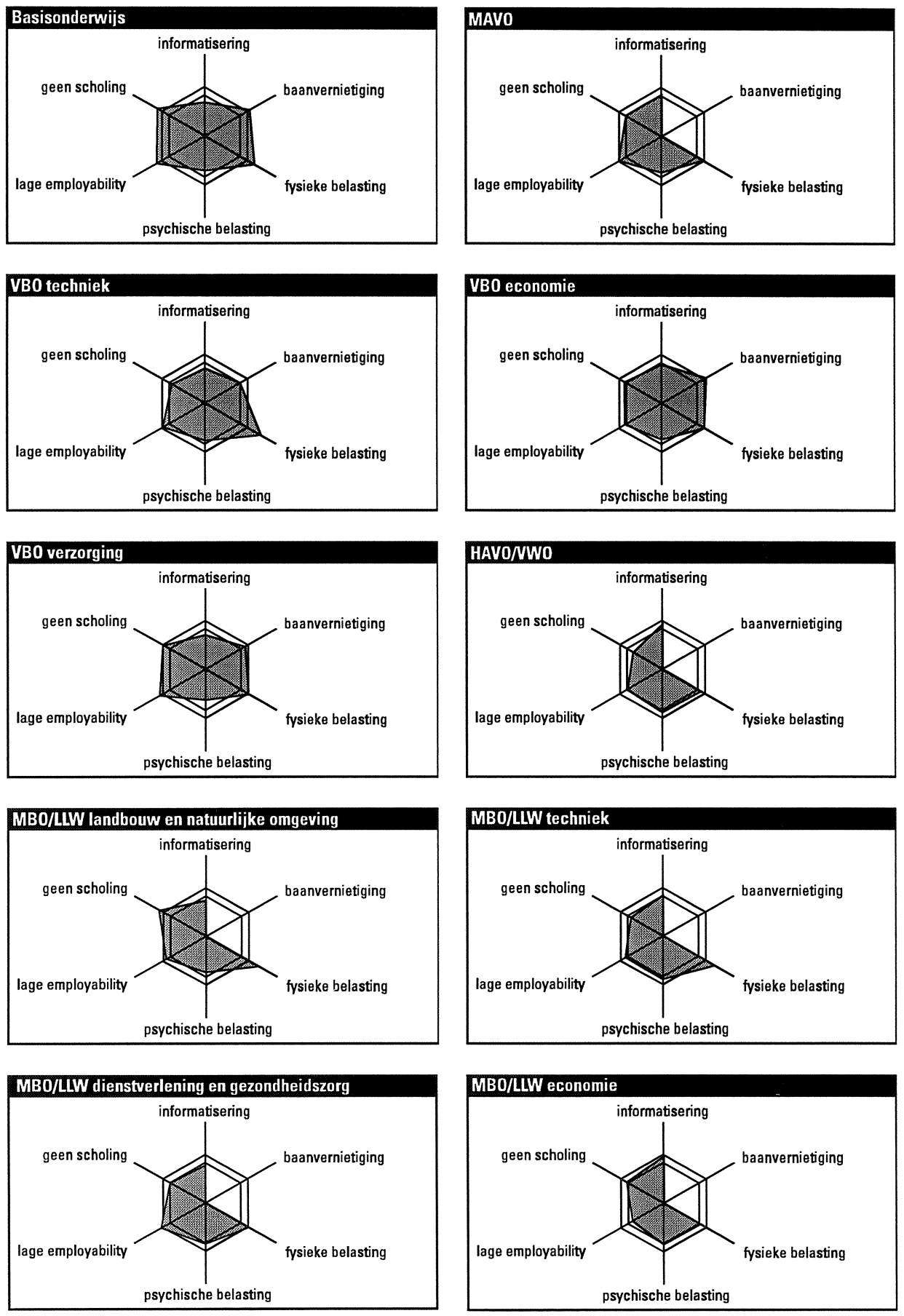

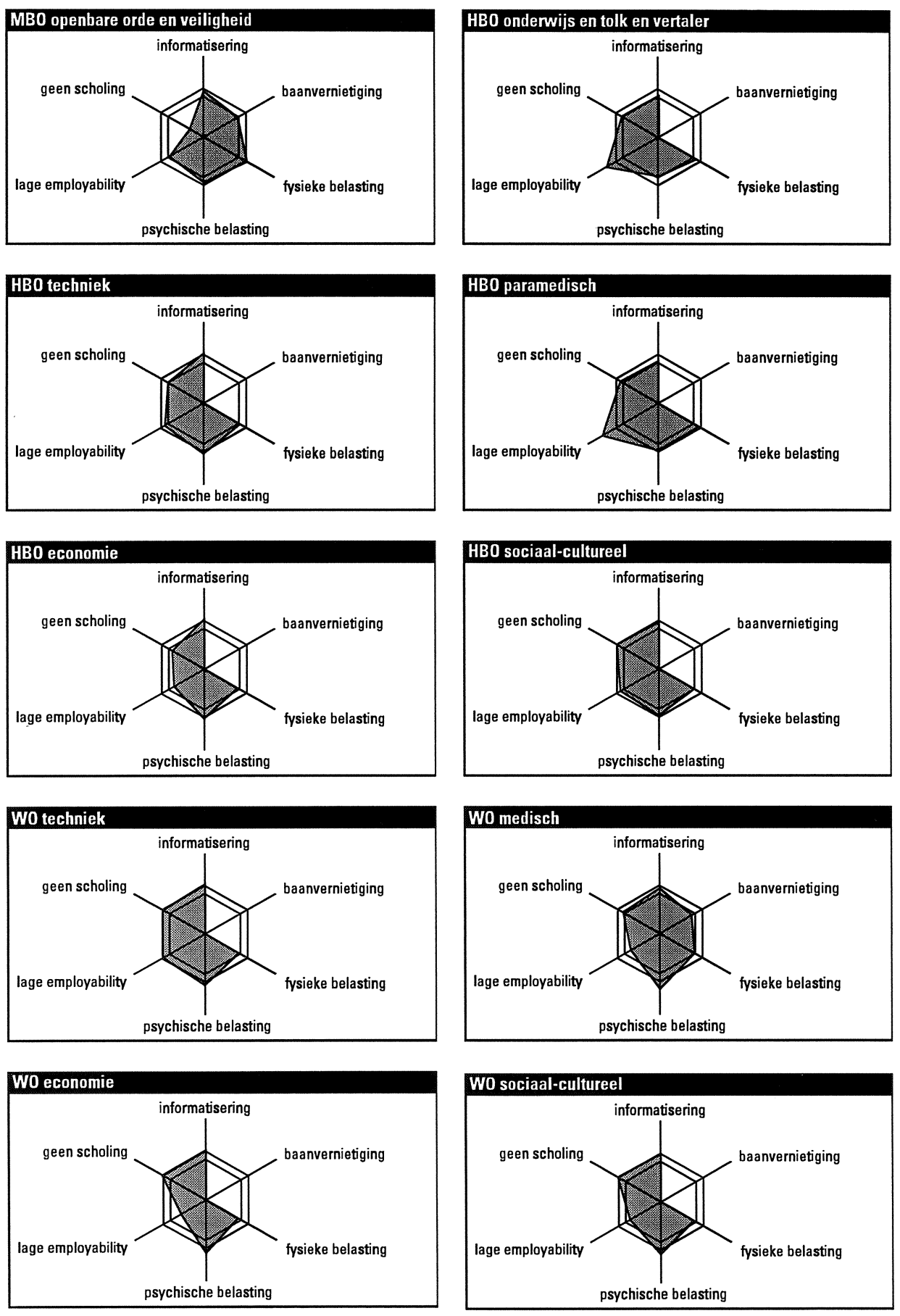